\title{
Visible-Light Responsive Sucrose-Containing Macrocyclic Host for Cations
}

\author{
Patrycja Sokołowska, Kajetan Dąbrowa,* and Sławomir Jarosz* \\ Institute of Organic Chemistry, Polish Academy of Sciences, ul. Kasprzaka 44/52, 01-224 \\ Warsaw, Poland
}

E-mail address: S.J.: slawomir.jarosz@icho.edu.pl, K.D.: kdabrowa@icho.edu.pl 


\section{Contents}

1. GENERAL REMARKS 3

1.1. Introduction 3

1.2. Computational details 3

2. SYNTHESIS $\quad 4$

\begin{tabular}{l} 
2.1. Synthesis of 6,6'-di-O-tritylsucrose (3) \\
\hline
\end{tabular}

2.2 Synthesis of $1^{\prime}, 2,3,3^{\prime}, 4,4^{\prime}$-hexa-O-benzyl-6,6'-di-O-tritylsucrose (4) 4

2.3. Synthesis of $1^{\prime}, 2,3,3^{\prime}, 4,4^{\prime}$-hexa-O-benzylsucrose (5) 5

2.4. Synthesis of $1^{\prime}, 2,3,3^{\prime}, 4,4^{\prime}$-hexa-O-benzyl-6,6'-bis[(2-chloroethoxy)-ethylsucrose (6). 5

2.5. Synthesis of $1^{\prime}, 2,3,3^{\prime}, 4,4^{\prime}$-hexa-O-benzyl-6,6'-bis[(2-iodoethoxy)ethylsucrose (7). 6

$\begin{array}{ll}\text { 2.6. General procedure for the synthesis of host } 1 & 7\end{array}$

2.7. Control experiments with TBA salts of carbonate, methoxide, and chloride 7

2.8. Synthesis of (S)-1-phenylethylamine trifluoromethanesulfonate (11). $\quad 8$

2.9. Synthesis of (R)-1-phenylethylamine trifluoromethanesulfonate (13). 8

2.10. Synthesis of cesium trifluoromethanesulfonate (15). 9

3. PHYSICOCHEMICAL AND PHOTOCHEMICAL PROPERTIES OF TRANS-1 AND CIS-19

$\begin{array}{ll}\text { 3.1. Characterization of host trans-1. } & 9\end{array}$

$\begin{array}{ll}\text { 3.2. Characterization of host cis-1. } & 11\end{array}$

3.3. Photochemical properties of hosts trans-1 and cis-1 and their complexes with cations 13

4. TITRATION EXPERIMENTS 15

$\begin{array}{lr}\text { 4.1. General remarks. } & 15\end{array}$

$\begin{array}{lr}\text { 4.2. Titration spectra } & 17\end{array}$

5. COPIES OF THE NMR SPECTRA 29

6. CARTESIAN COORDINATES OF CALCULATED STRUCTURES

7. REFERENCES 


\section{General remarks}

\subsection{Introduction}

Commercially available reagents were purchased from Sigma-Aldrich, Alfa Aesar or Th.Geyer, and used without purification as received. Hexanes $\left(65-80^{\circ} \mathrm{C}\right.$ fraction from petroleum) and EtOAc were purified by distillation. Thin-layer chromatography was carried out on silica gel 60 F254 (Merck). Compounds were purified using automatic flash chromatography on Buchi glass columns packed with silica gel 60 (230-400 mesh, Merck), using Knauer Smartline system with a Buchi fraction collector. The organic solutions were dried over MgSO4 or Na2SO4. The NMR spectra were recorded on Bruker Avance II $400 \mathrm{MHz}$ (at $400 \mathrm{MHz}, 376 \mathrm{MHz}$, and 100 $\mathrm{MHz}$ for ${ }^{1} \mathrm{H},{ }^{19} \mathrm{~F}$, and, ${ }^{13} \mathrm{C}$ NMR spectra, respectively), Varian VNMRS $500 \mathrm{MHz}$ (at $500 \mathrm{MHz}$ and $125 \mathrm{MHz}$ for ${ }^{1} \mathrm{H}$ and ${ }^{13} \mathrm{C}$ NMR spectra, respectively) or Varian VNMRS $600 \mathrm{MHz}$ (at 600 $\mathrm{MHz}$ and $150 \mathrm{MHz}$ for ${ }^{1} \mathrm{H}$ and ${ }^{13} \mathrm{C}$ NMR spectra, respectively) spectrometers using solutions in $\mathrm{CDCl}_{3}$, acetone- $d_{6}, \mathrm{CD}_{3} \mathrm{OD}$ or $\mathrm{CD}_{3} \mathrm{CN}$, and $\mathrm{TMS}$ or $\mathrm{TBAPF}_{6}$ as the internal standard at 303K. All significant resonances were assigned by COSY $(1 \mathrm{H}-1 \mathrm{H}), \mathrm{HSQC}\left(1 \mathrm{H}^{-13} \mathrm{C}\right)$ and HMBC $\left({ }^{1} \mathrm{H}_{-}{ }^{13} \mathrm{C}\right)$ correlations. Mass spectra were measured on Synapt G2-S HDMS (Waters Inc) mass spectrometer equipped with an electrospray ion source and q-TOF type mass analyzer. Elemental analyses were obtained with a Perkin-Elmer $2400 \mathrm{CHN}$ analyzer. Absorption spectra were recorded at room temperature unless otherwise stated in MeCN (for UV-spectroscopy, Fluka) on a Jasco J-715 spectropolarimeter with concentrations of $7.0 \times 10-5 \mathrm{M}$ in 0.1 $\mathrm{cm}$ quartz cell. All spectra were recorded using a $100 \mathrm{~nm} / \mathrm{min}$ scanning speed, a step size of 0.2 $\mathrm{nm}$, a bandwidth of $1 \mathrm{~nm}$, a response time of $0.5 \mathrm{~s}$, and an accumulation of 5 scans. The baseline of the spectra was corrected by subtracting the spectrum of the pure solvent recorded under the same conditions. Optical rotations were measured with a Jasco P 1020 polarimeter (sodium light) in chloroform at room temperature.

As light source the LED bulbs were used (commercial 3.3W GU10 bulbs containing 25 individual diodes: blue light $\lambda_{\max }=410 \pm 5 \mathrm{~nm}$, green light $\lambda_{\max }=530 \pm 5 \mathrm{~nm}$ ) and the sample of host 1 in the UV-cuvettes (quartz glass) was kept at ca. $2.5 \mathrm{~cm}$ distance from the bulb. No external cooling and light filter were used during experiments.

\subsection{Computational details}

To account for the solvent effect on the conformations and energies of the studied compounds, a conductor-like polarizable continuum model (C-PCM) in acetonitrile $(\varepsilon=37.5)$ was employed. Firstly, the structures of trans-1 and cis-1 and their complexes with potassium cation were subjected to comprehensive molecular mechanics simulations using the Spartan'18 software package. The obtained structures (up to 200 conformers) were then geometry optimized without any constrains at the semiempirical PM6 level of theory. Energies of these structures were then calculated at DFT/B3LYP-G3/6-31G(d) level of theory. Over a dozen conformers with the lowest energies were then subjected to final calculations using C-PCM solvent approximation. 


\section{Synthesis}

\subsection{Synthesis of $6,6^{\prime}$-di- $O$-tritylsucrose (3)}
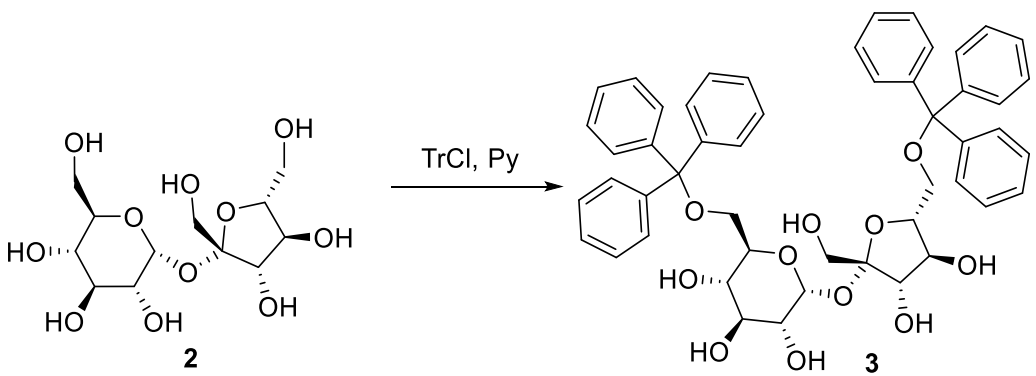

The compound was prepared as previously reported. ${ }^{1}$

Sucrose 2 (10.0 g, $29 \mathrm{mmol})$ was dissolved in boiling pyridine $(170 \mathrm{~mL}$, an oil bath was used for heating) containing DMAP (ca $40 \mathrm{mg}$ ). After cooling to room temperature, triphenylmethyl chloride (19.0 g; $68 \mathrm{mmol}$ ) was added in one portion and the mixture was stirred at $\mathrm{rt}$ for $48 \mathrm{~h}$. After cooling to room temperature, water $(150 \mathrm{~mL})$ was added and the products were extracted with ethyl acetate $(400 \mathrm{~mL})$. Combined organic solutions were washed with water $(2 \times 150$ $\mathrm{mL})$, brine $(150 \mathrm{~mL})$, dried over $\mathrm{Na}_{2} \mathrm{SO}_{4}$, concentrated, and the resulting residue was purified by column chromatography (hexane/ethyl acetate $=1: 2$ to $100 \%$ ethyl acetate) to afford $6,6^{\prime}$ di-O-tritylsucrose 3 as a white crystalline solid state $(12.4 \mathrm{~g}, 15 \mathrm{mmol}, 51 \%)$. $[\alpha]_{D}^{25}=+39.5(c$ 0.5, $\mathrm{CHCl}_{3}$ ). HRMS (ESI) m/z: $[\mathrm{M}+\mathrm{Na}]^{+} \mathrm{Calcd}$ for $\mathrm{C}_{50} \mathrm{H}_{50} \mathrm{O}_{11} \mathrm{Na}$ 849.3245; Found 849.3287. Anal. Calcd for $\mathrm{C}_{50} \mathrm{H}_{50} \mathrm{O}_{11}$ : C, 72.62; H, 6.09. Found: C, 72.36; H, 6.30.

\subsection{Synthesis of $1^{\prime}, 2,3,3^{\prime}, 4,4^{\prime}$-hexa- $O$-benzyl-6,6'-di- $O$-tritylsucrose (4)}

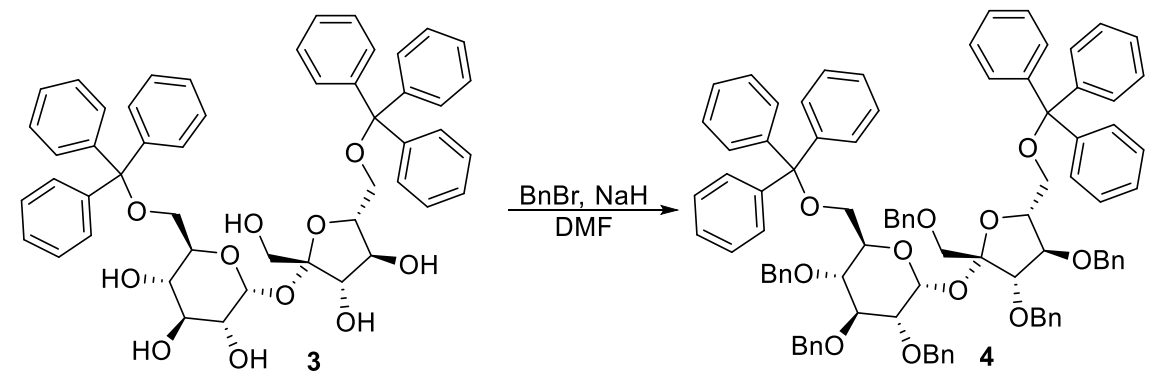

The compound was prepared as previously reported. ${ }^{1}$

To a stirred solution of compound 3 (3.8 g, $4.6 \mathrm{mmol})$ in DMF (100mL), was added sodium hydride (60\% dispersion in mineral oil, $1.45 \mathrm{~g}, 36 \mathrm{mmol}$ ) and the mixture was stirred at room temperature for $30 \mathrm{~min}$. Benzyl bromide $(3.7 \mathrm{ml}, 31.2 \mathrm{mmol})$ was added dropwise during 30 min and the mixture was stirred at $\mathrm{rt}$ for another $12 \mathrm{~h}$. Excess of hydride was decomposed carefully with methanol $(5 \mathrm{ml})$ and the mixture was partioned between water $(100 \mathrm{ml})$ and ethyl acetate $(100 \mathrm{ml})$. The organic phase was dried over $\mathrm{Na}_{2} \mathrm{SO}_{4}$, concentrated and the resulting residue was purified by column chromatography (hexane/ethyl acetate $=15: 1$ to $6: 1$ ) to afford the pure product 4 as a white amorphous solid $(5.03 \mathrm{~g}, 3.7 \mathrm{mmol}, 80 \%)$. $[\alpha]_{D}^{25}=+19.8\left(c 0.7, \mathrm{CHCl}_{3}\right)$. HRMS (ESI) m/z: $[\mathrm{M}+\mathrm{Na}]^{+}$Calcd for $\mathrm{C}_{92} \mathrm{H}_{86} \mathrm{O}_{11} \mathrm{Na}$ 1389.6067; Found 1389.6012. Anal. Calcd for $\mathrm{C}_{92} \mathrm{H}_{86} \mathrm{O}_{11}$ : C, 80.79; H, 6.34. Found: C, 80.62; H, 6.43. 


\subsection{Synthesis of $1^{\prime}, 2,3,3^{\prime}, 4,4^{\prime}$-hexa- $O$-benzylsucrose (5)}

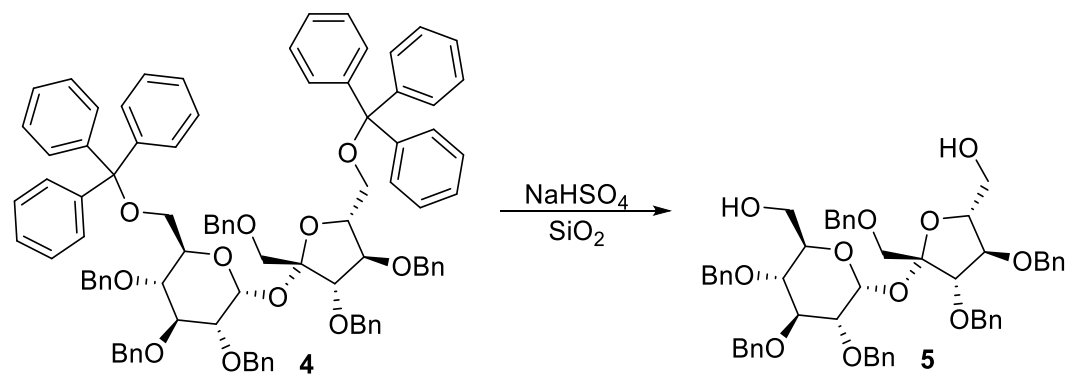

The above prepared $4(0.5 \mathrm{~g}, 0.37 \mathrm{mmol})$ was dissolved in a $\mathrm{CH}_{2} \mathrm{Cl}_{2} / \mathrm{MeOH}$ mixture $(10: 1 \mathrm{v} / \mathrm{v}$; $5 \mathrm{~mL})$ and the solution was stirred at $\mathrm{rt}$ for $5 \mathrm{~min}$. NaHSO $4(0.3 \mathrm{~g})$ and $\mathrm{SiO}_{2}(1.2 \mathrm{~g})$ was added and this mixture was stirred at rt until TLC (hexane/ethyl acetate $=9: 1$ ) indicated disappearance of the starting material (ca. $20 \mathrm{~h}$ ). The mixture was filtered and the residue was purified by flash chromatography (hexane/ethyl acetate $=9: 1$ ) to afford 6,6'-di-O-tritylsucrose 5 as a colorless oil (194 mg, $0.22 \mathrm{mmol}, 60 \%) .[\alpha]_{D}^{25}=+41.0\left(c 0.5, \mathrm{CHCl}_{3}\right)$.

${ }^{1} \mathrm{H}$ NMR $\left(\mathrm{CDCl}_{3}, 600 \mathrm{MHz}\right): \delta 5.49(\mathrm{~d}, 1 \mathrm{H}, J 1,2=3.6, \mathrm{H}-1), 4.86\left(\mathrm{dd}, 2 \mathrm{H}, 2 \times \mathrm{OC}_{2} \mathrm{Ph}\right), 4.76$ (d, $1 \mathrm{H}, J=10.9, \mathrm{OC} \underline{H} 2 \mathrm{Ph}), 4.71(\mathrm{~d}, 1 \mathrm{H}, J=11.5, \mathrm{OC} \underline{H} 2 \mathrm{Ph}), 4.69$ (d, 1H, $J=11.6, \mathrm{OC} \underline{H} 2 \mathrm{Ph})$, $4.67(\mathrm{~d}, 1 \mathrm{H}, J=12.0, \mathrm{OC} \underline{H} 2 \mathrm{Ph}), 4.62(\mathrm{~d}, 1 \mathrm{H}, J=11.6, \mathrm{OC} \underline{H} 2 \mathrm{Ph}), 4.60(\mathrm{~d}, 1 \mathrm{H}, J=11.1$, $\mathrm{OC} \underline{H} 2 \mathrm{Ph}), 4.57$ (d, 1H, $J=11.5, \mathrm{OC} \underline{H} 2 \mathrm{Ph}), 4.49$ (d, 1H, $J=11.7, \mathrm{OC} \underline{H} 2 \mathrm{Ph}), 4.47$ (d, 1H, $J=$ 12.1, OC플 Ph), 4.42 (d, 1H, $\left.J=7.6, \mathrm{H}^{\prime} 3^{\prime}\right), 4.33$ (t, 1H, $J=7.9, \mathrm{H}-4$ '), 4.31 (d, 1H, $J=12.0$, OC $\underline{H} 2 \mathrm{Ph}$ ), 4.15 (ddd, $1 \mathrm{H}, J=10.1,5.1,1.9, \mathrm{H}-5), 3.99$ (t, 1H, $J=9.4, \mathrm{H}-3), 3.96$ (dt, 1H, $J=$ 8.1, 2.4, H-5'), 3.82 (m, 2H, H-6, H6'), 3.63 (dd, 1H, J = 12.2, 5.2, H-6), 3.59 (dd, 1H, J = 12.7, 2.7, H-6'), 3.57 (d, 1H, $J=11.0, \mathrm{OC} \underline{H} 2 \mathrm{Ph}$ ), 3.50 (dd, 1H, $J=9.7, \mathrm{H}-2), 3.45$ (d, 1H, $J=11.0$, $\mathrm{OC} \underline{H} 2 \mathrm{Ph}), 3.43(\mathrm{~m}, 1 \mathrm{H}, \mathrm{H}-4) \mathrm{ppm}$.

${ }^{13} \mathrm{C}\{1 \mathrm{H}\} \mathrm{NMR}\left(\mathrm{CDCl}_{3}, 151 \mathrm{MHz}\right): \delta 138.6,138.3,138.1,138.1,138.0,137.7\left(\mathrm{C}_{\text {quat }}, 6 \times\right.$ $\mathrm{OCH}_{2} \underline{P h}$ ), 103.9 (C-2), 90.6 (C-1), 83.5 (C-3), 81.7 (C-4'), 80.9 (C-3), 79.8 (C-2), 79.5 (C-5'), 77.6 (C-4), 75.5, 74.9, 73.4, 73.3, $73.0\left(5 \times \mathrm{OC}_{\mathrm{C}} \mathrm{H}_{2} \mathrm{Ph}\right), 72.9,72.4,71.3,61.9,60.9$ (C-5, C-6', C6, C-1', $\left.\mathrm{O} \underline{\mathrm{C}} \mathrm{H}_{2} \mathrm{Ph}\right) \mathrm{ppm}$.

HRMS (ESI) $\mathrm{m} / \mathrm{z}[\mathrm{M}+\mathrm{Na}]^{+}$Calcd for $\mathrm{C}_{54} \mathrm{H}_{58} \mathrm{O}_{11} \mathrm{Na}$ 905.3876; Found 905.3906; Anal. Calcd for $\mathrm{C}_{54} \mathrm{H}_{58} \mathrm{O}_{11}$ : C, 73.45; H, 6.62. Found: $\mathrm{C}, 73.04 ; \mathrm{H}, 6.53$.

\subsection{Synthesis of $1^{\prime}, 2,3,3^{\prime}, 4,4^{\prime}$ 'hexa- $O$-benzyl-6,6'-bis[(2-chloroethoxy)-ethylsucrose (6).}
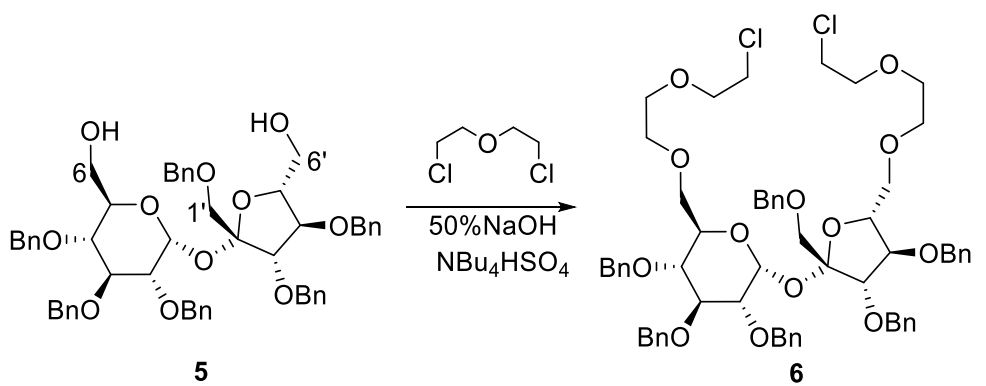

A solution of compound $5(100 \mathrm{mg}, 0.11 \mathrm{mmol})$ and tetrabutylammonium hydrogensulfate (38.5 g, $0.11 \mathrm{mmol})$ in bis(2-chloroethyl) ether $(284 \mu \mathrm{L}, 2.42 \mathrm{mmol})$ was vigorously stirred with $50 \% \mathrm{NaOH}$ solution $(423 \mu \mathrm{L})$ at room temperature for $3 \mathrm{~h}$. Then $\mathrm{CH}_{2} \mathrm{Cl}_{2}(1.5 \mathrm{~mL})$ and 
water $(1.5 \mathrm{~mL})$ were added, the organic layer was separated, and the aqueous one extracted with $\mathrm{CH}_{2} \mathrm{Cl}_{2}(2 \times 5 \mathrm{~mL})$. The combined organic solutions were washed with water $(2 \times 5 \mathrm{~mL})$, dried, and concentrated under high vacuum to remove the excess of bis(2-chloroethyl)ether. The crude material was purified by column chromatography (hexane/ethyl acetate $=80: 20$ ) to afford the title product 6 (92 $\mathrm{mg}, 0.08 \mathrm{mmol}, 74 \%)$ as an oil. $[\alpha]_{D}^{25}=+29.9\left(c 0.6, \mathrm{CHCl}_{3}\right)$.

${ }^{1} \mathrm{H}$ NMR $\left(\mathrm{CDCl}_{3}, 600 \mathrm{MHz}\right) \delta 5.66\left(\mathrm{~d}, 1 \mathrm{H}, J_{1,2}=3.6, \mathrm{H}-1\right), 4.90\left(\mathrm{~d}, 1 \mathrm{H}, J=10.9, \mathrm{OC}_{2} \mathrm{Ph}\right)$, $4.86\left(\mathrm{~d}, 1 \mathrm{H}, J=11.0, \mathrm{OC} \underline{H}_{2} \mathrm{Ph}\right), 4.76\left(\mathrm{~d}, 1 \mathrm{H}, J=10.9, \mathrm{OC} \underline{H}_{2} \mathrm{Ph}\right), 4.67(\mathrm{~d}, 1 \mathrm{H}, J=11.4$, $\left.\mathrm{OC} \underline{H}_{2} \mathrm{Ph}\right), 4,64$ (dd, 2H, OC $\left.\underline{H}_{2} \mathrm{Ph}\right), 4.58-4.54\left(\mathrm{~m}, 4 \mathrm{H}, \mathrm{OC} \underline{H}_{2} \mathrm{Ph}\right), 4.52\left(\mathrm{~d}, 1 \mathrm{H}, J=11.4, \mathrm{OC} \underline{H}_{2} \mathrm{Ph}\right)$, 4.44-4.40 (m, 2H, OC틀 $\mathrm{Ph}, \mathrm{H}-3$ '), 4.10 (m, 2H, H-4', H-5'), 4.04 (ddd, 1H, $J=10.2,3.3,1.9$, H-5), 3.94 (t, $J=9.3, \mathrm{H}-3), 3.75$ (d, $1 \mathrm{H}, J=11.0, \mathrm{H}-1$ 'a), 3.72-3.45 (m, 21H, -OC $\underline{H}_{2}-$, H-4, H2, $\left.2 \times \underline{\mathrm{C}}_{2}-\mathrm{Cl}\right), 3.42(\mathrm{dd}, 1 \mathrm{H}, J=10.8,1.8 \mathrm{~Hz}, \mathrm{H}-6 \mathrm{a}) \mathrm{ppm}$.

${ }^{13} \mathrm{C}\{1 \mathrm{H}\}$ NMR $\left(\mathrm{CDCl}_{3}, 151 \mathrm{MHz}\right) \delta 138.9,138.8,138.4,138.3,138.3,137.9\left(\mathrm{C}_{\text {quat }}, 6 \times\right.$ $\mathrm{OCH}_{2} \underline{\underline{P h}}$ ), 104.7 (C-2'), 90,2 (C-1), 83.9 (C-3'), 82.6 (C-4'), 81.9 (C-3), 79.8 (C-2), 79.8 (C5'), 77.5 (C-4), 75.5, 74.8, 73.4, 72.9, 72.3 (5 × $\left.\underline{\mathrm{C}}_{\mathrm{H}} \mathrm{Ph}\right), 72.7$ (C6'), 72.4, 71.4, 71.3, 71.0, 70.8, 70.5, 70.5 (C-7, C-8, C-9, C-7', C-8', C9', C1'), 70.6 (C-5), 69.7 (C-6), 42.8, 42.7 (2 × $\left.\underline{\mathrm{C}} \mathrm{H}_{2} \mathrm{Cl}\right) \mathrm{ppm}$.

HRMS (ESI) m/z [M + Na] ${ }^{+}$Calcd for $\mathrm{C}_{62} \mathrm{H}_{72} \mathrm{O}_{13} \mathrm{Cl}_{2} \mathrm{Na}$ 1117.4248; Found 1117.4211; Anal. Calcd for $\mathrm{C}_{62} \mathrm{H}_{72} \mathrm{O}_{13} \mathrm{Cl}_{2}$ : C, 67.94; H, 6.62; Cl, 6.47. Found: C, 67.94; H, 6.85; Cl, 6.43.

\subsection{Synthesis of $1^{\prime}, 2,3,3^{\prime}, 4,4^{\prime}$-hexa- $O$-benzyl-6,6'-bis[(2-iodoethoxy)ethylsucrose (7).}
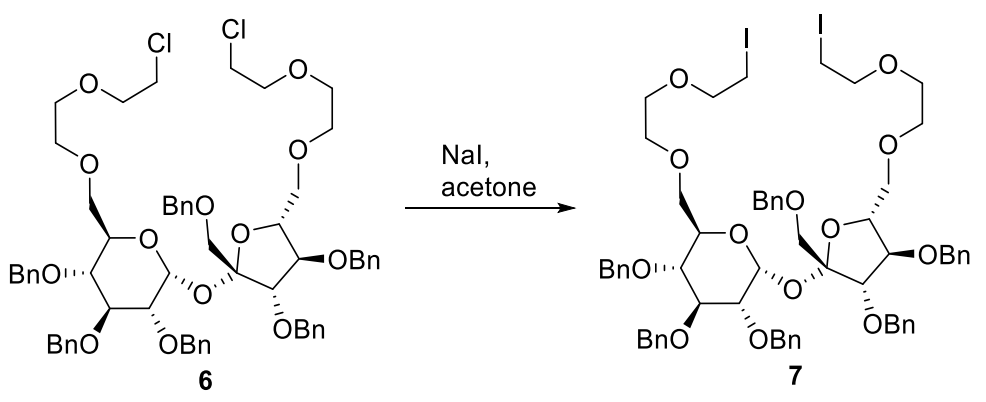

A solution of the bis-chloro derivative $6(813 \mathrm{mg}, 0.74 \mathrm{mmol})$ in dry acetone $(16 \mathrm{~mL})$ containing dry sodium iodide (444.7mg, $2.97 \mathrm{mmol}$ ) was stirred and boiled under reflux for $24 \mathrm{~h}$ (an oil bath). After cooling to rt., the precipitate was filtered off and washed with acetone. The combined acetone solutions were concentrated, and the residue was dissolved in $\mathrm{CH}_{2} \mathrm{Cl}_{2}(10 \mathrm{~mL})$. The organic phase was washed with water and dried to give 7 (900 mg, $0.73 \mathrm{mmol}, 95 \%)$ as an oil. $[\alpha]_{D}^{25}=+25.5\left(c 0.6, \mathrm{CHCl}_{3}\right)$.

${ }^{1} \mathrm{H} \mathrm{NMR}\left(\mathrm{CDCl}_{3}, 600 \mathrm{MHz}\right) \delta 5.65\left(\mathrm{~d}, 1 \mathrm{H}, J_{1,2}=3.6, \mathrm{H}-1\right), 4.90\left(\mathrm{~d}, 1 \mathrm{H}, J=10.9, \mathrm{OC}_{2} \mathrm{Ph}\right)$, $4.86\left(\mathrm{~d}, 1 \mathrm{H}, J=11.0, \mathrm{OC}_{2} \mathrm{Ph}\right), 4.76\left(\mathrm{~d}, 1 \mathrm{H}, J=10.9, \mathrm{OC} \underline{H}_{2} \mathrm{Ph}\right), 4.68(\mathrm{~d}, 1 \mathrm{H}, J=11.4$, $\left.\mathrm{OC} \underline{H}_{2} \mathrm{Ph}\right), 4,64$ (dd, $\left.2 \mathrm{H}, \mathrm{OC} \underline{H}_{2} \mathrm{Ph}\right), 4.58-4.54\left(\mathrm{~m}, 4 \mathrm{H}, \mathrm{OC} \underline{H}_{2} \mathrm{Ph}\right), 4.43-4.41\left(\mathrm{~m}, 2 \mathrm{H}, \mathrm{OC} \underline{H}_{2} \mathrm{Ph}\right.$,

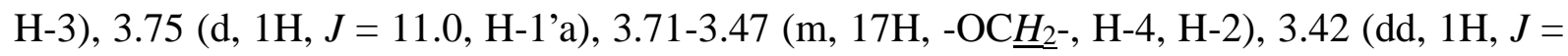
$10.8,1.8 \mathrm{~Hz}, \mathrm{H}-6 \mathrm{a}), 3.19-3.16\left(\mathrm{~m}, 2 \mathrm{H}, \underline{\mathrm{C}} \underline{H_{2}} \mathrm{I}\right), 3.15$ (t, $\left.J=6.9 \mathrm{~Hz}, 2 \mathrm{H}, \underline{\mathrm{C}}_{2} \mathrm{I}\right) \mathrm{ppm}$.

${ }^{13} \mathrm{C}\{1 \mathrm{H}\}$ NMR $\left(\mathrm{CDCl}_{3}, 151 \mathrm{MHz}\right) \delta: 138.9,138.8,138.4,138.3,138.3,137.9\left(\mathrm{C}_{\text {quat }}, 6 \times\right.$ $\mathrm{OCH}_{2} \underline{P h}$ ), 104.8 (C-2'), 90,3 (C-1), 83.9 (C-3'), 82.7 (C-4'), 81.9 (C-3), 79.8 (C-2), 79.8 (C- 
5'), 77.5 (C-4), 75.5, 74.9, 73.4, 72.9, 72.3 (5 × $\left.\mathrm{O}_{\mathbf{C H}} \mathrm{H}_{2} \mathrm{Ph}\right), 72.7$ (C6'), 72.4, 72.0, 71.9, 70.8, 70.8, 70.1, 70.1 (C-7, C-8, C-9, C-7', C-8', C9, C1), 70.6 (C-5), 69.7 (C-6), 3.1, $2.9\left(2 \times \underline{C H}_{2} \mathrm{I}\right)$ ppm.

HRMS (ESI) m/z [M + Na] $]^{+}$Calcd for $\mathrm{C}_{62} \mathrm{H}_{72} \mathrm{O}_{13} \mathrm{I}_{2} \mathrm{Na}$ 1301.2960; Found 1301.2955; Anal. Calcd for $\mathrm{C}_{62} \mathrm{H}_{72} \mathrm{O}_{13} \mathrm{I}_{2}$ : C, 58.22; H, 5.67; I, 19.84. Found: C, 58.12; H, 5.67; I, 19.79 .

\subsection{General procedure for the synthesis of host 1}
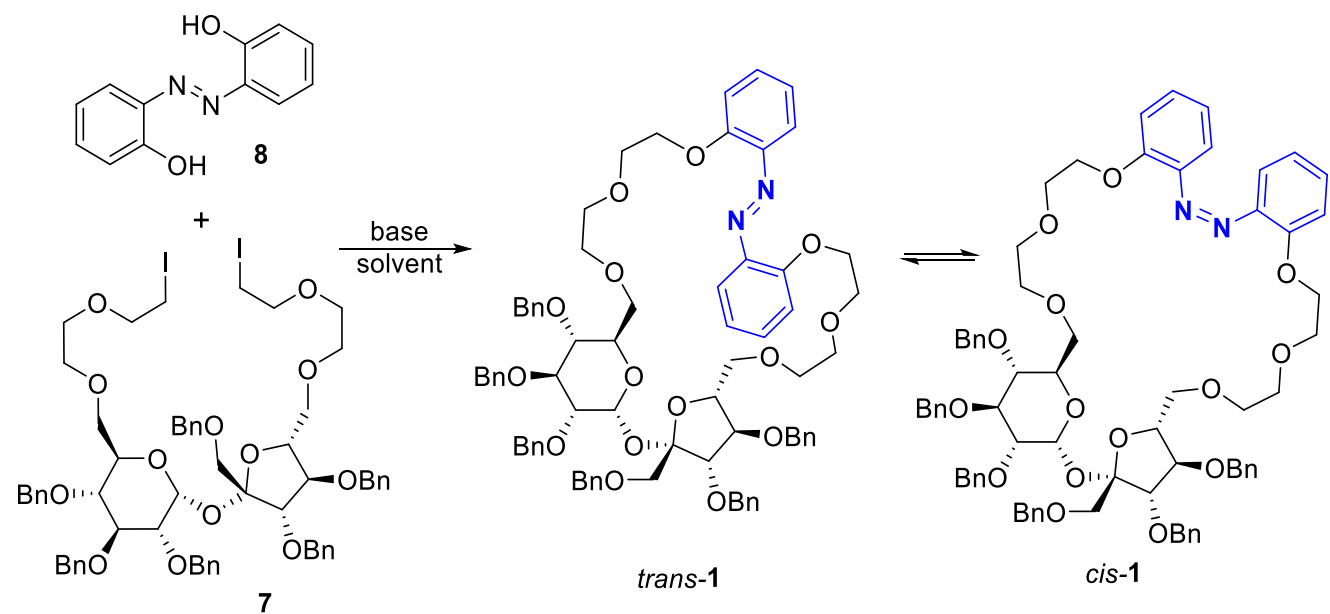

To a solution of $7(120 \mathrm{mg}, 0.09 \mathrm{mmol})$ and $\mathbf{8}(20 \mathrm{mg}, 0.09 \mathrm{mmol}$ in dry acetonitrile $(5 \mathrm{~mL})$, powdered cesium carbonate $(244 \mathrm{mg}, 0.75 \mathrm{mmol}$ ) was added and the mixture was heated to $82^{\circ} \mathrm{C}$ using an oil bath and stirred for 6 hours under argon atmosphere. After cooling to rt., water $(10 \mathrm{~mL})$ was added and the products were extracted with ethyl acetate $(2 \times 10 \mathrm{~mL})$. The organic phase was dried over $\mathrm{Na}_{2} \mathrm{SO}_{4}$, concentrated and the resulting residue was purified by column chromatography (hexane/ethyl acetate $=4: 1$ to $1: 1 \mathrm{v} / \mathrm{v}$ ) to afford pure compounds trans$\mathbf{1}$ and cis-1 $^{\$}$ as color glaze (99 $\mathrm{mg}, 0.08 \mathrm{mmol}, 85.3 \%$ ).

\$ Trans-1 spontaneously isomerize to cis-1 during workup and column chromatography under ambient light. The procedure for preparation of pure trans-1 is given in Section 3.1.

\subsection{Control experiments with TBA salts of carbonate, methoxide, and chloride}

Macrocyclisation using di-tetrabutylammonium carbonate $\left(\mathrm{TBA}_{2} \underline{\mathrm{CO}}_{3}\right)$ :

The tetrabutylammonium carbonate $\left(\mathrm{TBA}_{2} \mathrm{CO}_{3}\right)$ was prepared by the reported procedure. ${ }^{2}$ To a solution of $7(52 \mathrm{mg}, 0.041 \mathrm{mmol})$ and $\mathbf{8}(8.7 \mathrm{mg}, 0.041 \mathrm{mmol})$ in $\mathrm{MeCN}(3 \mathrm{~mL})$ was added $\mathrm{TBA}_{2} \mathrm{CO}_{3}(177 \mathrm{mg}, 0.32 \mathrm{mmol})$ and the mixture was heated to $82^{\circ} \mathrm{C}$ using an oil bath and stirred for 24 hours under argon atmosphere. After cooling to rt. water $(10 \mathrm{~mL})$ was added and the solution was extracted with ethyl acetate $(2 \times 10 \mathrm{~mL})$, dried over anhydrous $\mathrm{Na}_{2} \mathrm{SO}_{4}$ and concentrated. Analysis of the residue reveals only traces of product $\mathbf{1}$ along with a substantial amount of unidentified polar residues, probably oligomers derived from $\mathbf{7}$ and $\mathbf{8}$.

Macrocyclisation using tetrabutylammonium methoxide (TBAOMe):

To a solution of 7 (54 mg, $0.042 \mathrm{mmol})$ and $\mathbf{8}(9 \mathrm{mg}, 0.042 \mathrm{mmol})$ in $\mathrm{MeCN}$ (3mL) was added $\mathrm{TBAOMe}^{\$}(92.4 \mathrm{mg}, 0.34 \mathrm{mmol})$ and the reaction mixture was stirred at $82^{\circ} \mathrm{C}$ for 24 hours 
under argon atmosphere. After cooling to rt. water $(10 \mathrm{~mL})$ was added and the solution was extracted with ethyl acetate $(2 \times 10 \mathrm{~mL})$, dried over anhydrous $\mathrm{Na}_{2} \mathrm{SO}_{4}$ and concentrated. Analysis of the residue reveals only traces of product 1 along with some amount of terminal olefin derived by methoxide E2-type elimination of $\alpha, \omega$-diiodo substrate 7 .

\$ Neat TBAOMe was prepared by low-temperature evaporation of solvent under reduced pressure from the commercially available $20 \%$ wt TBAOMe in $\mathrm{MeOH}$ and was used immediately in the macrocyclisation reaction.

Additional ${ }^{1} \mathrm{H}$ NMR experiment reveals that host 1 is stable to TBAOMe, at least for 48 in refluxing $\mathrm{MeCN}-d_{3}$.

Macrocyclisation using tetrabutylammonium chloride (TBACl) and cesium carbonate $\underline{\left(\mathrm{Cs}_{2}\right.} \underline{\left.\mathrm{CO}_{3}\right):}$

To a solution of $7(50 \mathrm{mg}, 0.039 \mathrm{mmol})$ and $\mathbf{8}(8.4 \mathrm{mg}, 0.039 \mathrm{mmol})$ in acetonitrile $(3 \mathrm{~mL})$ were added sequentially $\mathrm{Cs}_{2} \mathrm{CO}_{3}(85.5 \mathrm{mg}, 0.31 \mathrm{mmol})$ and $\mathrm{TBACl}(201 \mathrm{mg}, 0.72 \mathrm{mmol})$ and the mixture was heated to $82^{\circ} \mathrm{C}$ using an oil bath and stirred for 6 hour under argon atmosphere. After cooling to rt. water $(10 \mathrm{~mL})$ was added and the solution was extracted with ethyl acetate $(2 \times 10 \mathrm{~mL})$, dried over anhydrous $\mathrm{Na}_{2} \mathrm{SO}_{4}$, concentrated, and the resulting residue was purified by column chromatography (hexane/ethyl acetate $=4: 1$ to $1: 1 \mathrm{v} / \mathrm{v}$ ) to afford trans/cis-mixture of 1 as color glaze (18 $\mathrm{mg}, 0.015 \mathrm{mmol}, 37 \%$ ).

\subsection{Synthesis of (S)-1-phenylethylamine trifluoromethanesulfonate (11).}

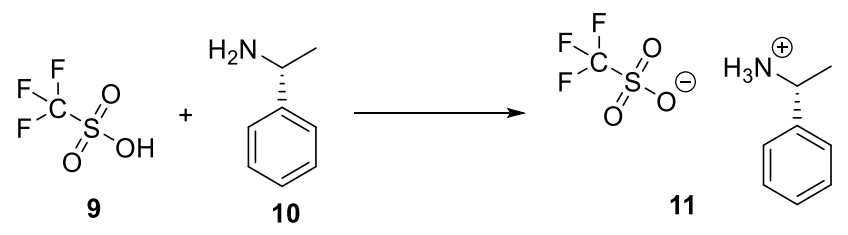

A solution of trifluoromethanesulfonic acid $(192 \mu \mathrm{l}, 2.2 \mathrm{mmol})$ in diethyl ether $(20 \mathrm{ml})$ was vigorously stirred under argon atmosphere at room temperature. Then (S)-(-)-1-Phenylethylamine $(280 \mu \mathrm{l}, 2.2 \mathrm{mmol})$ was added dropwise in $10 \mathrm{~min}$. The white solid precipitate was filtered, and the cake was washed with a minimal amount of cold diethyl ether and then dried in a vacuum oven overnight to afford $561 \mathrm{mg}(93 \%)$ of white solid product. ${ }^{1} \mathrm{H}$ NMR $\left(\mathrm{CD}_{3} \mathrm{CN}\right.$, $400 \mathrm{MHz}) \delta 7.57-7.29(\mathrm{~m}, 5 \mathrm{H}), 6.84(\mathrm{~s}, 2 \mathrm{H}), 4.53(\mathrm{q}, J=6.9 \mathrm{~Hz}, 1 \mathrm{H}), 1.63(\mathrm{~d}, J=6.9 \mathrm{~Hz}, 3 \mathrm{H})$. ${ }^{13} \mathrm{C}\{1 \mathrm{H}\} \mathrm{NMR}\left(\mathrm{CD}_{3} \mathrm{CN}, 101 \mathrm{MHz}\right) \delta: 138.39,130.27,130.09,127.94,53.26,20.36,20.26 \mathrm{ppm}$. ${ }^{19} \mathrm{~F} \mathrm{NMR}\left(\mathrm{CD}_{3} \mathrm{CN}, 376 \mathrm{MHz}\right) \delta$ : $-79.35 \mathrm{ppm}$. Anal. calcd for $\mathrm{C}_{9} \mathrm{~F}_{3} \mathrm{H}_{12} \mathrm{NO}_{3} \mathrm{~S}: \mathrm{C}, 39.85 ; \mathrm{H}, 4.46$; N, 5.16; found: C, 39.85; H, 4.40; N, 5.26.

\subsection{Synthesis of (R)-1-phenylethylamine trifluoromethanesulfonate (13).}

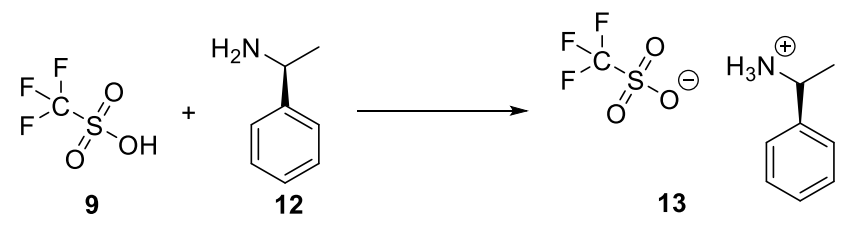


A solution of trifluoromethanesulfonic acid $(192 \mu 1,2.2 \mathrm{mmol})$ in diethyl ether $(20 \mathrm{ml})$ was vigorously stirred under argon atmosphere at room temperature. Then (S)-(-)-1-Phenylethylamine $(280 \mu 1,2.2 \mathrm{mmol})$ was added dropwise in $10 \mathrm{~min}$. The white solid precipitate was filtered, and the cake was washed with a minimal amount of cold diethyl ether and then dried in a vacuum oven overnight to afford $556 \mathrm{mg}(90 \%)$ of white solid product. ${ }^{1} \mathrm{H}$ NMR $\left(\mathrm{CD}_{3} \mathrm{CN}\right.$, $400 \mathrm{MHz}) \delta 7.57-7.29(\mathrm{~m}, 5 \mathrm{H}), 6.84(\mathrm{~s}, 2 \mathrm{H}), 4.53(\mathrm{q}, J=6.9 \mathrm{~Hz}, 1 \mathrm{H}), 1.63(\mathrm{~d}, J=6.9 \mathrm{~Hz}, 3 \mathrm{H})$. ${ }^{13} \mathrm{C}\{1 \mathrm{H}\} \mathrm{NMR}\left(\mathrm{CD}_{3} \mathrm{CN}, 101 \mathrm{MHz}\right) \delta: 138.39,130.27,130.09,127.94,53.26,20.36,20.26 \mathrm{ppm}$. ${ }^{19} \mathrm{~F} \mathrm{NMR}\left(\mathrm{CD}_{3} \mathrm{CN}, 376 \mathrm{MHz}\right) \delta$ : -79.36 ppm. Anal. calcd for $\mathrm{C}_{9} \mathrm{~F}_{3} \mathrm{H}_{12} \mathrm{NO}_{3} \mathrm{~S}: \mathrm{C}, 39.85 ; \mathrm{H}, 4.46$; N, 5.16; found: C, 39.86; H, 4.39; N, 5.27.

\subsection{Synthesis of cesium trifluoromethanesulfonate (15).}

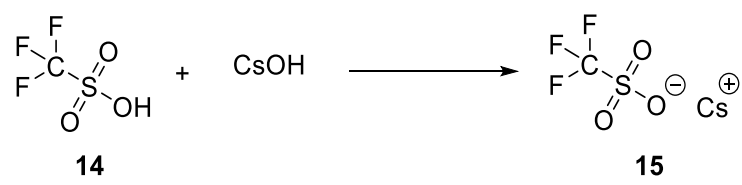

A solution of $10 \mathrm{~g}$ ( $66.6 \mathrm{mmol})$ of cesium hydroxide in $20 \mathrm{~mL}$ of water was added dropwise carefully via a dropping funnel to $6.3 \mathrm{ml}, 10 \mathrm{~g}(66.6 \mathrm{mmol})$ of triflic acid chilled in an ice bath. The solution was stirred at $0^{\circ} \mathrm{C}$ for $20 \mathrm{~min}$, then it was concentrated to dryness using a rotary evaporator, and $\mathrm{MeCN}(\sim 50 \mathrm{~mL})$ was added to the residual solid and the procedure was repeated. The white solid was dissolved while hot in the minimum amount of $\mathrm{MeCN}$, and then it was precipitated by the addition of $\mathrm{Et}_{2} \mathrm{O}(100 \mathrm{~mL})$. The solid was filtered on a glass funnel $\mathrm{G} 4$, washed with $\mathrm{Et}_{2} \mathrm{O}(\sim 50 \mathrm{~mL})$, and dried in a vacuum oven overnight to afford $14.9 \mathrm{~g}$ of pure cesium triflate $(79 \%) .{ }^{19} \mathrm{~F} \mathrm{NMR}\left(\mathrm{CD}_{3} \mathrm{CN}, 376 \mathrm{MHz}\right) \delta$ : $-79.65 \mathrm{ppm}$. Anal. calcd for $\mathrm{CsCF}_{3} \mathrm{SO}_{3}$ : C, 4.26; S, 11.37; found: C, 4.25; S, 11.37 .

\section{Physicochemical and photochemical properties of trans-1 and cis-1}

\subsection{Characterization of host trans-1.}

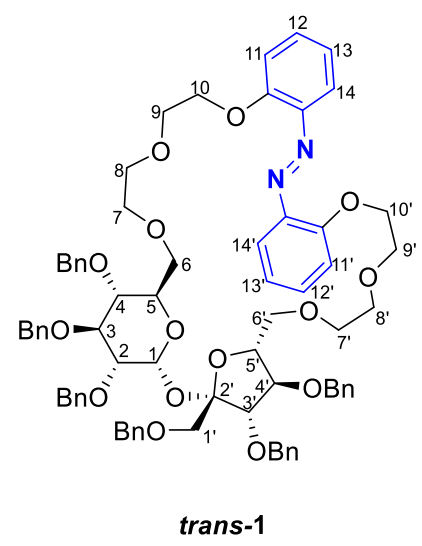

Host trans $\mathbf{- 1}$ is the thermodynamically stable isomer, albeit its broad absorption in the visible region of the light $(400-600 \mathrm{~nm})$ induces partial trans-to-cis isomerization even by ambient light. To obtain pure trans-1, the compound was kept in an amber glass container at high temperature (up to $\sim 70^{\circ} \mathrm{C}$ for a solution of $\mathbf{1}$ in $\mathrm{MeCN}$ ) for an appropriate time (usually 24-48h). 
Afterwards, the pure trans-1 was covered with aluminum foil to prevent incidental light exposure. Solutions of trans $\mathbf{- 1}$ in non-amber glass for the ${ }^{1} \mathrm{H}$ NMR experiments were handled under red-light conditions to prevent any isomerization.

Trans-enriched mixture of 1 was prepared upon irradiation with blue light (410 nm, LED 3W) for varying amounts of time, depending on the concentration of the solution used ( 2-4 min for $1-6 \cdot 10^{-5} \mathrm{M}$ and up to $20 \mathrm{~min}$ for $\left.\sim 10^{-2} \mathrm{M}\right)$. After irradiation, the trans-enriched solution of host 1 was covered with aluminum foil to ensure no changes in the trans/cis ratio due to incident light.

${ }^{1} \mathrm{H}$ NMR $\left(\mathrm{CD}_{3} \mathrm{CN}, 600 \mathrm{MHz}\right) \delta: 7.38$ (ddd, $\left.1 \mathrm{H}, J=8.4,7.3,1.8, \mathrm{H}-14\right), 7.37$ (ddd, $1 \mathrm{H}, J=8.3$, 7.3, 1.7, H-14'), 7.32 (m, 2H, H-11, H-11'), 7.12 (dd, 1H, J = 8.3, 1.2, H-13), 7.09 (dd, 1H, $J$ $=8.4,1.1, \mathrm{H}-13$ ') 7.0 (dddd, $2 \mathrm{H}, J=7.9,7.3,1.7,1.1, \mathrm{H}-12, \mathrm{H}-12^{\prime}$ ), 5.49 (d, 1H. $J=3.5, \mathrm{H}-$ 1), $4.77\left(\mathrm{~d}, 1 \mathrm{H}, J=11.2,(\mathrm{C}-3) \mathrm{OC} \underline{H}_{2} \mathrm{Ph}\right), 4.71\left(\mathrm{~d}, 1 \mathrm{H}, J=11.1,(\mathrm{C}-4) \mathrm{OC} \underline{H}_{2} \mathrm{Ph}\right), 4.66(\mathrm{~d}, 1 \mathrm{H}, J$ $\left.=11.2,(\mathrm{C}-3) \mathrm{OC} \underline{H}_{2} \mathrm{Ph}\right), 4.69-4.58\left(\mathrm{~m}, 3 \mathrm{H},\left(\mathrm{C}-3^{\prime}\right) \mathrm{OC} \underline{H}_{2} \mathrm{Ph},\left(\mathrm{C}-4^{\prime}\right) \mathrm{OC} \underline{\mathrm{H}}_{2} \mathrm{Ph},(\mathrm{C}-2) \mathrm{OC} \underline{\mathrm{H}}_{2} \mathrm{Ph}, 4.54\right.$ $\left(\mathrm{d}, 1 \mathrm{H}, J=11.9\right.$, (C-4')OC$\left.\underline{H}_{2} \mathrm{Ph}\right), 4.51-4.46\left(\mathrm{~m}, 4 \mathrm{H},(\mathrm{C}-4) \mathrm{OC} \underline{H}_{2} \mathrm{Ph},(\mathrm{C}-2) \mathrm{OC} \underline{H}_{2} \mathrm{Ph},(\mathrm{C}-\right.$ $\left.\left.3^{\prime}\right) \mathrm{OC} \underline{H}_{2} \mathrm{Ph},\left(\mathrm{C}-1^{\prime}\right) \mathrm{OC} \underline{H}_{2} \mathrm{Ph}\right), 4.39$ (d, $1 \mathrm{H}, J=11.9$, (C-1') $\left.\mathrm{OC}_{2} \mathrm{Ph}\right), 4.28$ (d, $1 \mathrm{H}, J=7.8, \mathrm{H}-$ 3'), 4.26-4.22 (m, 4H, 2×H-10, 2×H-10'), 3.98 (t, 1H, J = 7.9, H-4'), 3.82-3.72 (m, 6H, H-5,

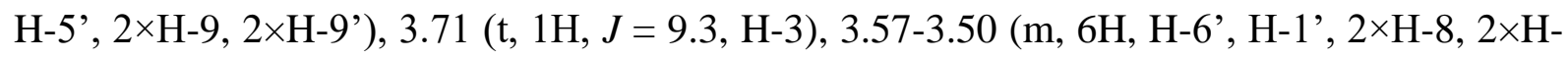
8'), 3.48 (dd, 1H, J =11.0, 3.3, H-6'), 3.43-3.35 (m, 5H, H-1', 2×H-7', H-4, H-7), 3.34 (dd, 1H, $J=9.7,3.3, \mathrm{H}-2), 3.29(\mathrm{dd}, 1 \mathrm{H}, J=11.2,3.7, \mathrm{H}-6), 3.25-3.21(\mathrm{~m}, 1 \mathrm{H}, \mathrm{H}-7), 3.19$ (dd, $1 \mathrm{H}, J=$ 11.2, 1.7, H-6) ppm.

${ }^{13} \mathrm{C}\{1 \mathrm{H}\} \mathrm{NMR}\left(\mathrm{CD}_{3} \mathrm{CN}, 151 \mathrm{MHz}\right) \delta: 155.40,155.33\left(\mathrm{C}_{\text {quat }}, 2 \times \mathrm{N}=\mathrm{N} \underline{P h}\right), 143.88,143.85\left(\mathrm{C}_{\text {quat }}\right.$, $2 \times \mathrm{O} \underline{P h}), 139.24,139.04,138.66,138.54,138.49,138.30\left(\mathrm{C}_{\text {quat }}, 6 \times \mathrm{OCH}_{2} \underline{P h}\right), 131.93,131.92$ (C-14, C-14'), 128.34, 128.29, 128.28, 128.23, 128.21, 128.18, 127.98, 127.91, 127.86, 127.81, $127.71,127.67,127.63,127.56,127.53,127.50,127.40,127.34\left(18 \times \mathrm{OCH}_{2} \underline{P h}\right), 120.97,120.95$ (C-12, C-12'), 117.96, 117.92 (C-11, C-11'), 114.79 (C-13'), 114.72 (C-13), 103.92 (C-2'), 89.15 (C-1), 83.25 (C-3'), 81.60 (C-3), 81.44 (C-4'), 79.90 (C-2), 79.37 (C-5'), 77.49 (C-4), $74.78\left((\mathrm{C}-3) \mathrm{OCH}_{2} \mathrm{Ph}\right), 74.24\left((\mathrm{C}-4) \mathrm{OCH}_{2} \mathrm{Ph}\right), 72.93\left(\left(\mathrm{C}-1^{\prime}\right) \mathrm{OC}_{2} \mathrm{Ph}\right), 72.32\left(\left(\mathrm{C}-3^{\prime}\right) \mathrm{OC}_{2} \underline{H}_{2} \mathrm{Ph}\right)$, 72.10 ((C-4') $\left.\mathrm{OCH}_{2} \mathrm{Ph}\right), 72.03$ ((C-2)OC_H$\left.{ }_{2} \mathrm{Ph}\right), 71.77$ (C-6'), 71.74 (C-1'), 70.68 (C-5), 70.62 (C-8), 70.60 (C-7), 70.38 (C-7'), 70.28 (C-8'), 69.56 (C10), 69.53 (C6), 69.41 (C-10'), 69.40 (C-9), 69.33 (C-9') ppm. HRMS (ESI) m/z [M + Na $]^{+}$Calcd for $\mathrm{C}_{74} \mathrm{H}_{80} \mathrm{~N}_{2} \mathrm{O}_{15} \mathrm{Na}$ 1259.5456; Found 1259.5486; Anal. Calcd for $\mathrm{C}_{74} \mathrm{H}_{80} \mathrm{~N}_{2} \mathrm{O}_{15}$ : C, 71.83; H, 6.52; N, 2.26. Found: C, 71.66; H, 6.52; N, 2.26. 


\subsection{Characterization of host cis-1.}

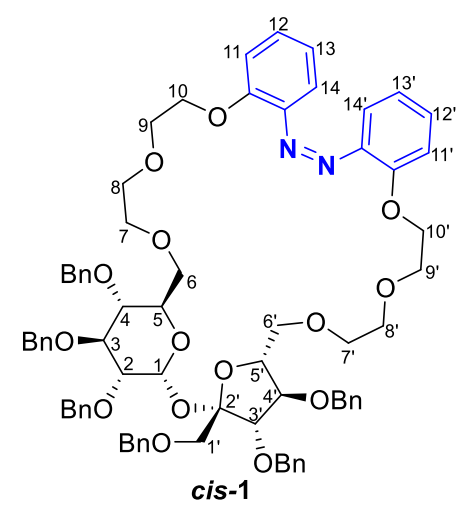

Host cis-1 was prepared as a cis-enriched mixture upon irradiation of the host solution in $\mathrm{MeCN}$ with green light (530 nm, LED 3W) for varying amounts of time, depending on the concentration of the solution used ( 1-5 min for $1-6 \cdot 10^{-5} \mathrm{M}$ and up to $30 \mathrm{~min}$ for $\left.\sim 10^{-2} \mathrm{M}\right)$. After irradiation, the cis-enriched solution of host $\mathbf{1}$ was covered with aluminum foil to ensure no changes in the trans/cis ratio due to incident light. Due to the relatively high thermal stability of cisisomer (see Table S1), it was assumed that the concentration of cis-1 was kept constant during the experiments in $\mathrm{MeCN}$ at $\mathrm{rt}$ (the longest experiments took up to $\sim 3 \mathrm{~h}$ for the NMR measurements).

${ }^{1} \mathrm{H}$ NMR $\left(\mathrm{CD}_{3} \mathrm{CN}, 600 \mathrm{MHz}\right) \delta: 7.09$ (m, 2H, H-14, H-14'), 6.87 (ddd, 2H, $J=8.4,6.2,1.1, \mathrm{H}-$ 13, H-13'), 6.76 (td, 1H, $J=7.6,1.1, \mathrm{H}-12$ ), 6.73 (td, 1H, $J=7.6,1.1, \mathrm{H}-12$ ') 6.69 (dd, $1 \mathrm{H}, J$ $=7.8,1.7, \mathrm{H}-11), 6.65$ (dd, $1 \mathrm{H}, J=7.8,1.7, \mathrm{H}-11$ '), 5.62 (d, 1H. $J=3.5, \mathrm{H}-1), 4.80$ (d, 1H, $J=$ $\left.11.2,(\mathrm{C}-3) \mathrm{OC} \underline{H}_{2} \mathrm{Ph}\right), 4.76\left(\mathrm{~d}, 1 \mathrm{H}, J=11.1,(\mathrm{C}-4) \mathrm{OC} \underline{H}_{2} \mathrm{Ph}\right), 4.68(\mathrm{~d}, 1 \mathrm{H}, J=11.2$, (C-

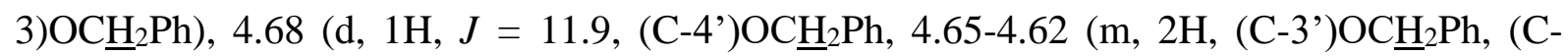
2) $\left.\mathrm{OC} \underline{H}_{2} \mathrm{Ph}\right), 4.61\left(\mathrm{~d}, 1 \mathrm{H}, J=11.8,\left(\mathrm{C}-4^{\prime}\right) \mathrm{OC} \underline{H}_{2} \mathrm{Ph}\right), 4.55\left(\mathrm{~d}, 1 \mathrm{H}, J=11.3,(\mathrm{C}-4) \mathrm{OC} \underline{H}_{2} \mathrm{Ph}\right), 4.54-$ $4.49\left(\mathrm{~m}, 3 \mathrm{H},\left(\mathrm{C}-3^{\prime}\right) \mathrm{OC} \underline{H}_{2} \mathrm{Ph},(\mathrm{C}-2) \mathrm{OC} \underline{H}_{2} \mathrm{Ph},\left(\mathrm{C}-1^{\prime}\right) \mathrm{OC}_{2} \mathrm{Ph}\right), 4.41(\mathrm{~d}, 1 \mathrm{H}, J=11.9$, (C$\left.1^{\prime}\right) \mathrm{OC} \underline{H}_{2} \mathrm{Ph}$ ), 4.33 (d, 1H, $J=7.8, \mathrm{H}-3$ '), 4.12 (t, 1H, $J=7.9, \mathrm{H}-4$ '), 4.0-3.85 (m, 6H, 2×H-10, $2 \times \mathrm{H}-10$ ', H-5, H-5'), 3.77 (t, 1H, $J=9.3, \mathrm{H}-3$ ), 3.72 (dd, 1H, H-6'), 3.68-3.62 (m, 5H, 2×H-9, $2 \times \mathrm{H}_{-}$', H-6'), 3.62-3.50 (m, 8H, 2×H-8, 2×H-8', 2×H-7', H-7, H-1 '), 3.50-3.45 (m, 2H, H-4. H-1'), 3.45-3.36 (m, 4H, 2×H-6, H-7, H-2) ppm.

${ }^{13} \mathrm{C}\{1 \mathrm{H}\} \mathrm{NMR}\left(\mathrm{CD}_{3} \mathrm{CN}, 151 \mathrm{MHz}\right) \delta: 148.70,148.27\left(\mathrm{C}_{\text {quat }}, 2 \times \mathrm{N}=\mathrm{N} \underline{P h}\right), 143.78,143.78\left(\mathrm{C}_{\text {quat }}\right.$, $2 \times \mathrm{O} \underline{P h}), 139.23,139.00,138.66,138.62,138.52,138.33\left(\mathrm{C}_{\text {quat }}, 6 \times \mathrm{OCH}_{2} \underline{P h}\right), 128.61,128.60$ (C-14, C-14'), 128.61, 128.60, 128.34, 128.32, 128.28, 128.26, 128.23, 128.19, 128.01, 127.93, $127.90,127.82,127.74,127.71,127.64,127.59,127.56,127.50,127.44,127.35\left(18 \times \mathrm{OCH}_{2} \underline{P h}\right)$, 120.10 (C-12), 120.00 (C-12'), 119.81 (C-11), 119.58 (C-11'), 113.32, 113.25 (C-13, C-13'), 104.02 (C-2'), 89.20 (C-1), 83.30 (C-3’), 81.64 (C-3), 81.39 (C-4'), 79.95 (C-2), 79.51 (C-5'), $77.66(\mathrm{C}-4), 74.80\left((\mathrm{C}-3) \mathrm{OCH}_{2} \mathrm{Ph}\right), 74.29\left((\mathrm{C}-4) \mathrm{OCH}_{2} \mathrm{Ph}\right), 72.95\left(\left(\mathrm{C}-1^{\prime}\right) \mathrm{O} \underline{C H}_{2} \mathrm{Ph}, 72.37\right.$,

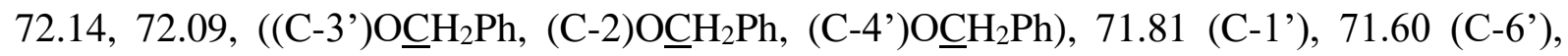
70.81 (C-5), 70.65 (C-7), 70.44, 70.44, 70.25, (C-8, C-8', C-7'), 69.67 (C-6), 69.14, 69.12 (C9, C-9'), 68.11, 68.11 (C-10, C-10’) ppm.

HRMS (ESI) m/z [M + Na ${ }^{+}$Calcd for $\mathrm{C}_{74} \mathrm{H}_{80} \mathrm{~N}_{2} \mathrm{O}_{15} \mathrm{Na}$ 1259.5456; Found 1259.5486; Anal. Calcd for $\mathrm{C}_{74} \mathrm{H}_{80} \mathrm{~N}_{2} \mathrm{O}_{15}$ : C, 71.83; H, 6.52; N, 2.26. Found: C, 71.66; H, 6.52; N, 2.26. 
a)

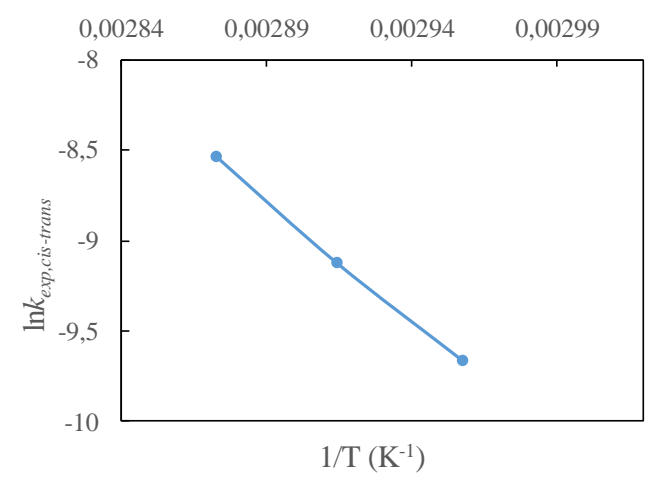

b)

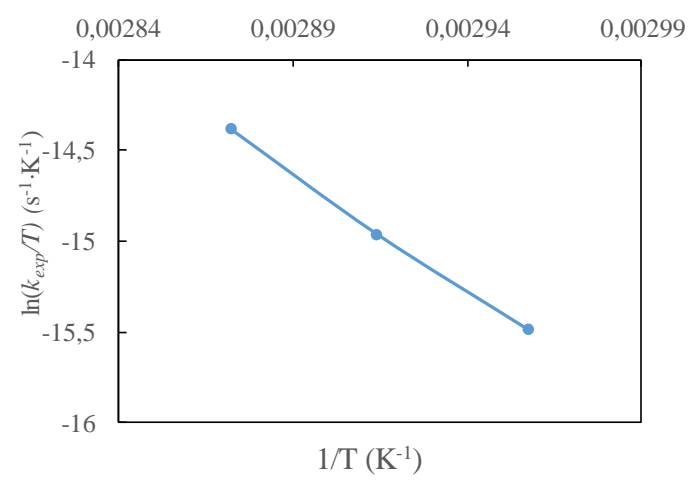

Fig. S1. Arrhenius (a) and van't Hoff (b) plots of thermal cis $\rightarrow$ trans isomerization of $\mathbf{1}$.

Table S1. Kinetic and thermodynamic data for thermal isomerization of $\operatorname{cis}^{\text {-1 }}{ }^{[\mathrm{a}]}$

\begin{tabular}{|c|c|c|c|c|c|}
\hline$k_{\text {cis } \rightarrow \operatorname{trans}} \cdot 10^{-7}\left(\mathrm{~s}^{-1}\right)$ & $\begin{array}{l}\tau_{1 / 2} \\
(\mathrm{~h})\end{array}$ & $\mathrm{E}_{\mathrm{a}}$ & $\Delta \mathrm{H}^{\#}$ & $\mathrm{~T} \Delta \mathrm{S}^{\#}$ & $\Delta \mathrm{G}^{[\mathrm{b}]}$ \\
\hline 3.23 & 596 & 110.5 & 107.7 & -2.4 & 110.0 \\
\hline \multicolumn{6}{|c|}{$\begin{array}{l}\text { [a] Corresponding values at } 298 \mathrm{~K} \text { were measured in MeCN and determined using } \\
\text { Arrhenius and Eyring equations; } c_{\text {host }}=5 \cdot 10^{-5} \mathrm{M} \text {; the values for } E_{a}, \Delta H^{\#} \text {, and } \Delta G^{\#} \text { are } \\
\text { given in } \mathrm{kJ} \cdot \mathrm{mol}^{-1} \text {, and for } \mathrm{T} \Delta S \# \text { in } \mathrm{J} \cdot \mathrm{mol}^{-1} \cdot[\mathrm{b}] \text { Calculated using equation: } \Delta \mathrm{H}-\mathrm{T} \Delta \mathrm{S} \text {. }\end{array}$} \\
\hline
\end{tabular}


3.3. Photochemical properties of hosts trans -1 and cis-1 and their complexes with cations Host cis-1 was prepared

a)

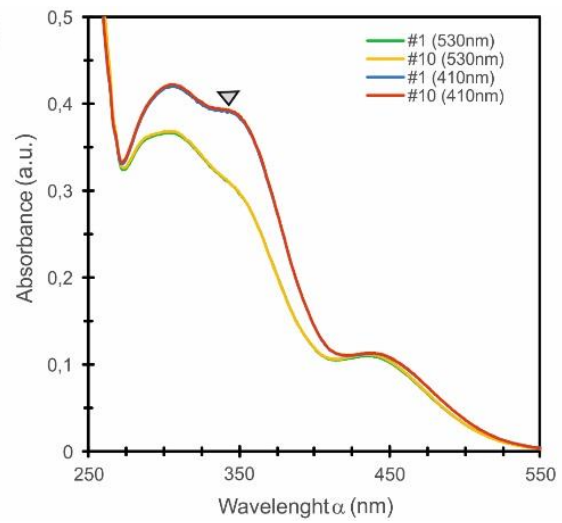

b)

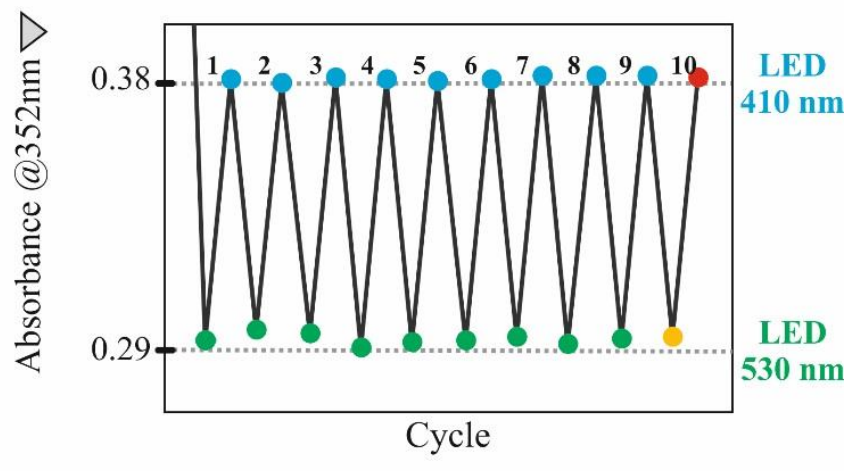

Fig. S2. Photoswitching between trans -1 and cis-1 in MeCN at 298.0 $\pm 0.1 \mathrm{~K}$ using green light $(530 \mathrm{~nm})$ and blue light $(410 \mathrm{~nm})$, respectively.

a)

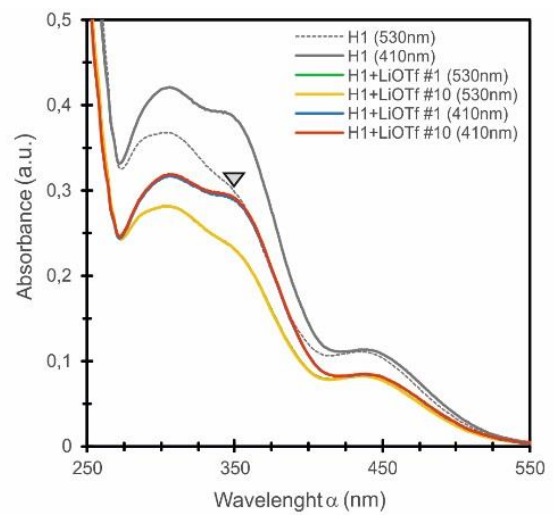

b)

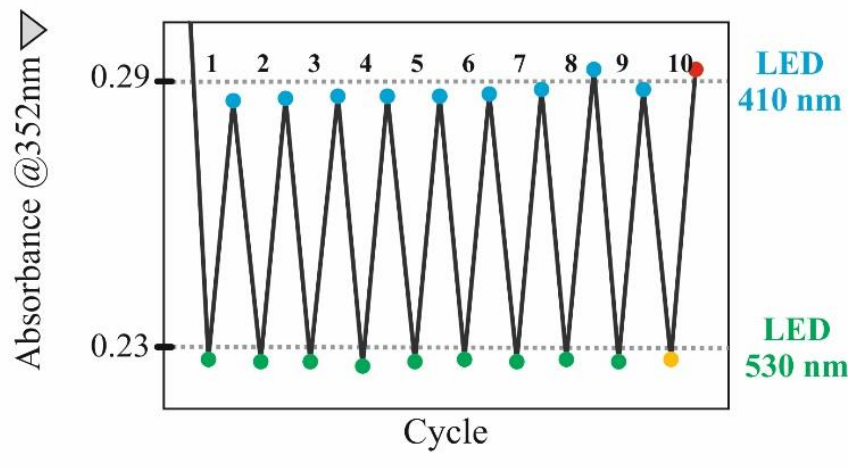

Fig. S3. Photoswitching between complexes of trans-1 and cis-1 with LiOTf (100 equiv) in $\mathrm{MeCN}$ at 298.0 $\pm 0.1 \mathrm{~K}$ using green light $(530 \mathrm{~nm})$ and blue light $(410 \mathrm{~nm})$, respectively.

a)

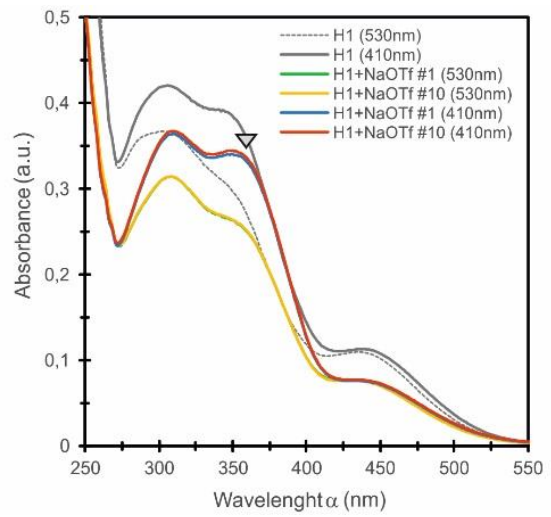

b)

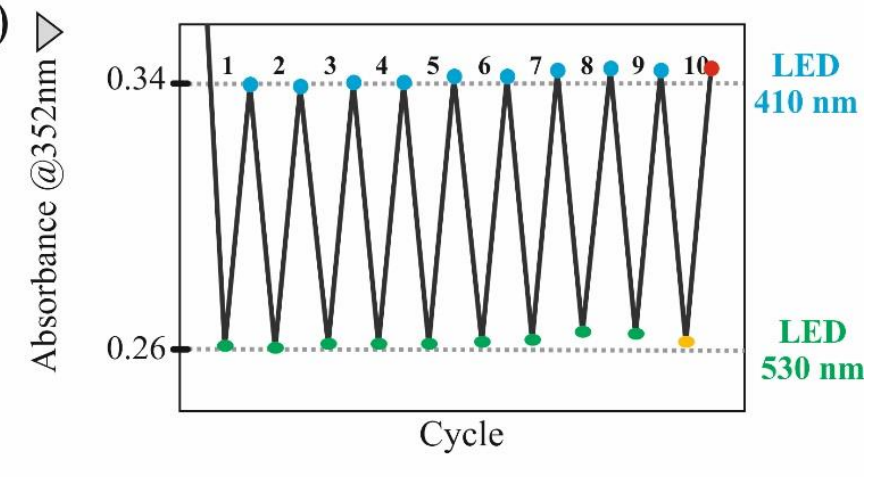

Fig. S4. Photoswitching between complexes of trans-1 and cis-1 with NaOTf (100 equiv) in $\mathrm{MeCN}$ at $298.0 \pm 0.1 \mathrm{~K}$ using green light $(530 \mathrm{~nm})$ and blue light $(410 \mathrm{~nm})$, respectively. 
a)

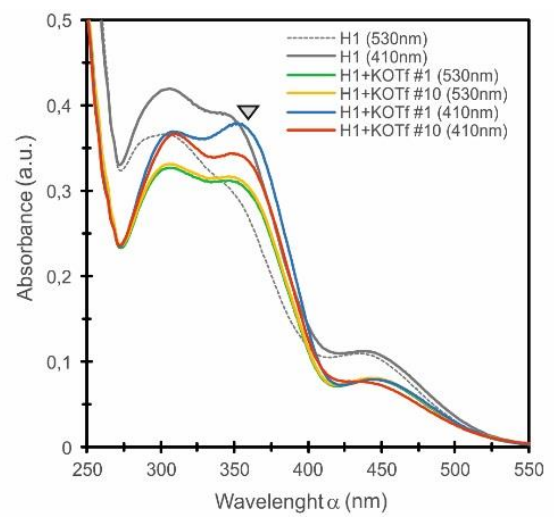

b)

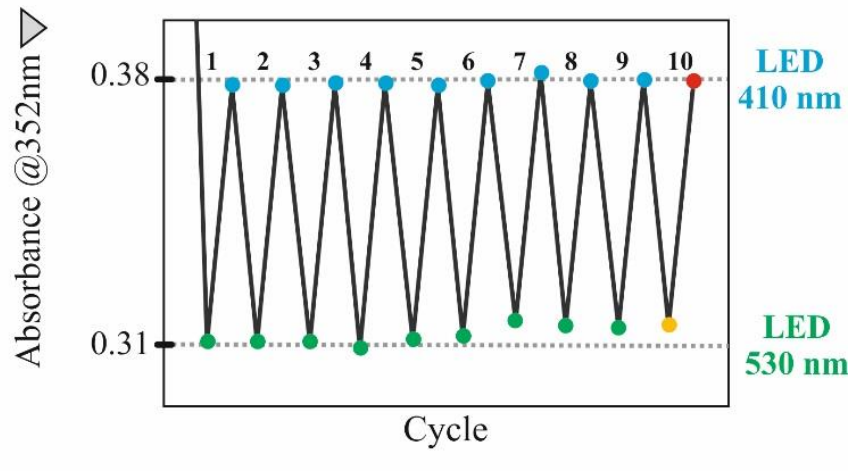

Fig. S5. Photoswitching between complexes of trans-1 and cis-1 with KOTf (10 equiv) in $\mathrm{MeCN}$ at 298.0 $\pm 0.1 \mathrm{~K}$ using green light $(530 \mathrm{~nm})$ and blue light $(410 \mathrm{~nm})$, respectively.

a)

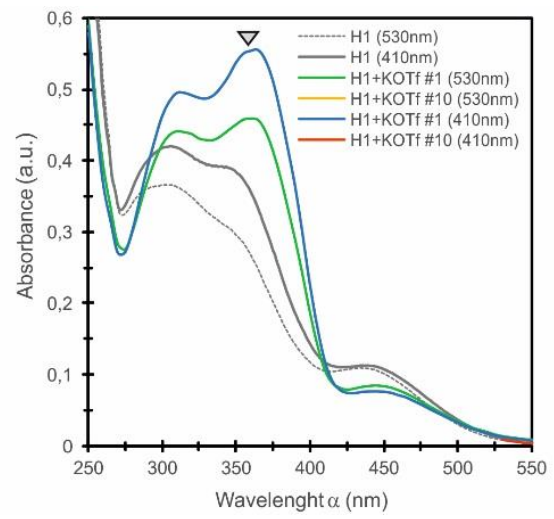

b)

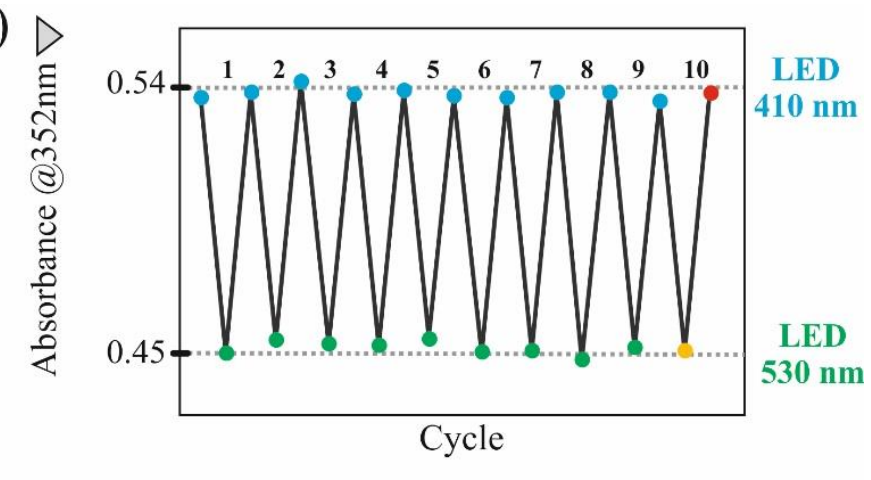

Fig. S6. Absorption spectra and photoswitching of a solution of trans/cis-1 with KOTf (100 equiv) in $\mathrm{MeCN}$ at $298.0 \pm 0.1 \mathrm{~K}$ using green light $(530 \mathrm{~nm})$ and blue light $(410 \mathrm{~nm})$, respectively.

a)

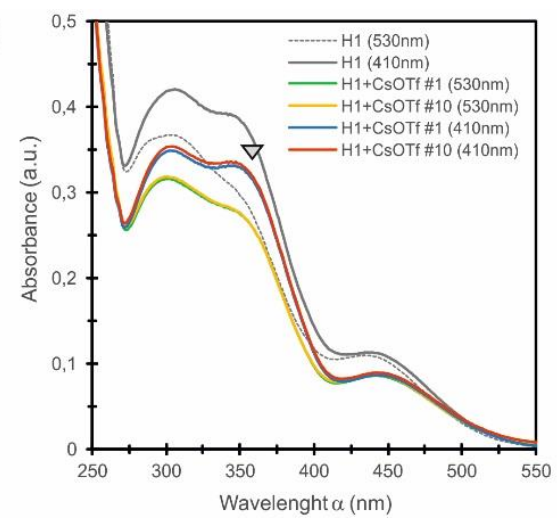

b)

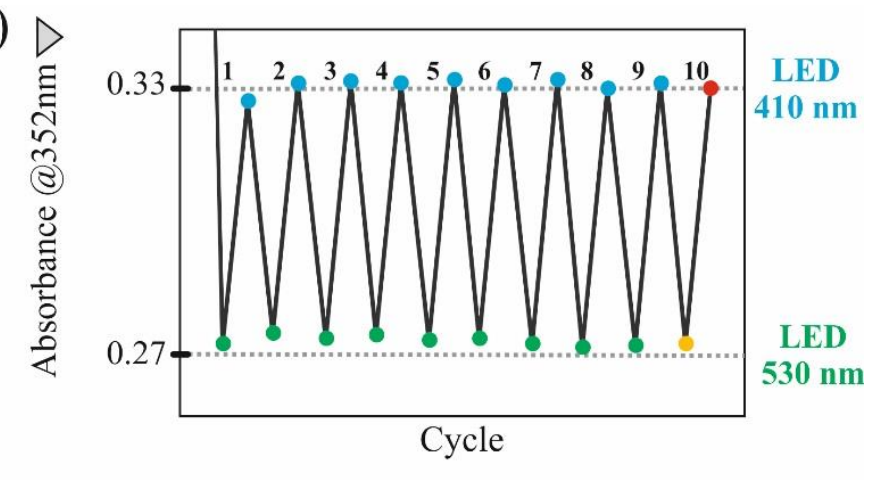

Fig. S7. Photoswitching between complexes of trans-1 and cis-1 with CsOTf (100 equiv) in $\mathrm{MeCN}$ at 298.0 $\pm 0.1 \mathrm{~K}$ using green light $(530 \mathrm{~nm})$ and blue light $(410 \mathrm{~nm})$, respectively. 


\section{Titration experiments}

\subsection{General remarks.}

Commercially available triflate (TfO) salts (LiOTf, NaOTf, and KOTf) were used as received. CsOTf, (S)-1-PEA, and (R)-PEA salts were prepared as described in Sections 2.11, 2.9, and 2.10 , respectively. The titration experiments were conducted as described previously. ${ }^{3} \mathrm{~A}$ simultaneous nonlinear curve fitting for all protons belonging to the receptor and TBA salts, and assuming 1:1 binding model for both trans-1 and cis-1, was carried out with the HypNMR 2008 software. ${ }^{4}$ This procedure provides more reliable $\mathrm{K}_{\mathrm{a}}$ 's (so-called global association constant) than fitting of the experimental data to a single chemical signal changes. ${ }^{5}$ Determination of $K_{\mathrm{a}}$ 's for $c i s-\mathbf{1}$ was carried out using fully relaxed values of $\mathrm{K}_{\mathrm{a}}$ 's for trans-1 which were generally similar, i.e. within experimental error, to those obtained during titration of pure trans- $\mathbf{1}$ in the dark. However, when the fitting algorithm failed to converge, fixed values of $K_{\text {a }}$ 's for trans-1 were instead used to determine $K_{\mathrm{a}}$ for $c i s-\mathbf{1}$. The details of the titration experiments are given in Table S2.

Table S2. Titration details, global stability constants $K_{\mathrm{a}}\left(\mathrm{M}^{-1}\right)$, and selected maximum signal shifts $\left(\Delta \delta_{\max }\right)$ of anomeric $\mathrm{CH}(1)$ proton for trans-1 and cis-1 with various cations in $\mathrm{MeCN}-\mathrm{d}_{3}$ at $303 \mathrm{~K}^{\text {[a] }}$

\begin{tabular}{|c|c|c|c|c|c|c|}
\hline Host & Guest $^{[\mathrm{b}]}$ & $\mathrm{c}_{\text {Host }}(\mathrm{M})$ & $\mathrm{c}_{\text {Guest }}(\mathrm{M})$ & $K_{\mathrm{a}}\left(\mathrm{M}^{-1}\right)$ & $K_{\text {cis }} / K_{\text {trans }}$ & $\begin{array}{c}\Delta \delta_{\max , \mathrm{CH}(1)} \\
\quad(\mathrm{ppm})\end{array}$ \\
\hline trans $-\mathbf{1}^{[\mathrm{c}]}$ & \multirow{2}{*}{$\mathrm{Li}^{+}$} & 0.0089 & 0.3461 & $36.8 \pm 0.7$ & \multirow{2}{*}{$0.57 \pm 0.05$} & -0.05 \\
\hline$c i s-\mathbf{1}^{[\mathrm{d}]}$ & & 0.0101 & 0.4134 & $20.8 \pm 3.4$ & & 0.03 \\
\hline $\operatorname{trans}-\mathbf{1}^{[\mathrm{c}]}$ & \multirow{2}{*}{$\mathrm{Na}^{+}$} & 0.0089 & 0.3441 & $210.5 \pm 1.8$ & \multirow{2}{*}{$2.12 \pm 0.03$} & -0.68 \\
\hline$c i s-\mathbf{1}^{[\mathrm{d}]}$ & & 0.0101 & 0.3386 & $446.6 \pm 6.8$ & & 0.24 \\
\hline trans $-\mathbf{1}^{[\mathrm{c}]}$ & \multirow{2}{*}{$\mathrm{K}^{+}$} & 0.0089 & 0.2627 & $1023.3 \pm 12.5$ & \multirow{2}{*}{$2.71 \pm 0.06$} & -1.02 \\
\hline$c i s-\mathbf{1}^{[\mathrm{d}]}$ & & 0.0089 & 0.2629 & $2776.5 \pm 86.3$ & & 0.29 \\
\hline $\operatorname{trans}-\mathbf{1}^{[\mathrm{c}]}$ & \multirow{2}{*}{$\mathrm{Cs}^{+}$} & 0.0101 & 0.4551 & $90.4 \pm 1.0$ & \multirow{2}{*}{$4.10 \pm 0.05$} & -0.11 \\
\hline$c i s-\mathbf{1}^{[\mathrm{d}]}$ & & 0.0101 & 0.4480 & $370.3 \pm 5.0$ & & 0.05 \\
\hline $\operatorname{trans}-\mathbf{1}^{[\mathrm{c}]}$ & \multirow{2}{*}{ (S)-PEAH ${ }^{+}$} & 0.0089 & 0.2149 & $19.4 \pm 0.6$ & \multirow{2}{*}{$2.00 \pm 0.04$} & -0.18 \\
\hline$c i s-\mathbf{1}^{[\mathrm{d}]}$ & & 0.0089 & 0.7398 & $38.8 \pm 0.2$ & & -0.24 \\
\hline $\operatorname{trans}-\mathbf{1}^{[\mathrm{c}]}$ & \multirow{2}{*}{ (R)-PEAH ${ }^{+}$} & 0.0089 & 0.2096 & $21.8 \pm 0.6$ & \multirow{2}{*}{$1.95 \pm 0.05$} & -0.24 \\
\hline$c i s-\mathbf{1}^{[\mathrm{d}]}$ & & 0.0092 & 0.7398 & $42.5 \pm 1.0$ & & -0.38 \\
\hline
\end{tabular}

[a] Determined by ${ }^{1} \mathrm{H}$ NMR titration experiments and nonlinear curve fitting using HypNMR 2008 software; ${ }^{4 c}$ for host cis-1 total host concentration is given for a mixture of trans- and cis-isomers; [b] cations added as triflate (TfO) salts; [c] titration carried out in dark; [d] titration conducted immediately after irradiation with green light (LED $3 W, \lambda=530 \mathrm{~nm}$ ). 


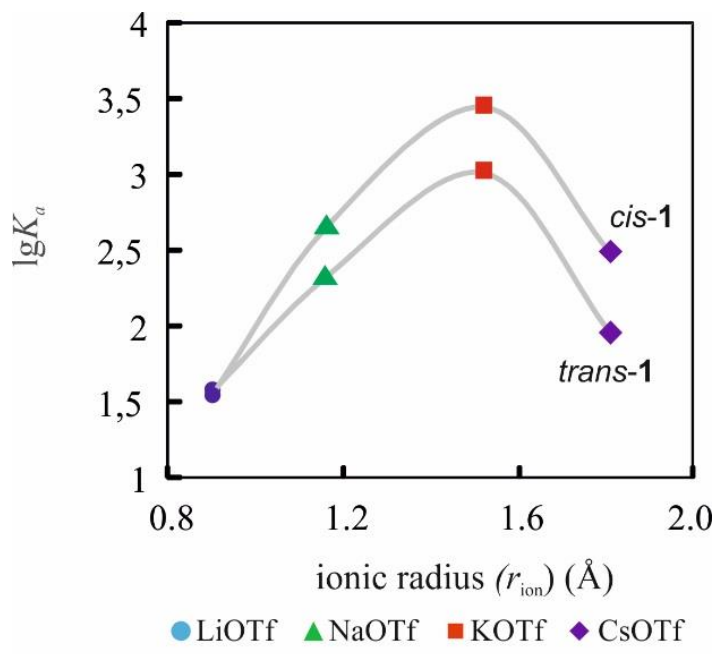

Fig. S8. Dependence of the stability of the complex $\left(\lg K_{\mathrm{a}}\right)$ on the ionic radius $\left(\mathrm{r}_{\text {ion }}\right)$ of alkali metal cations (added as trifalte salt). 


\subsection{Titration spectra}

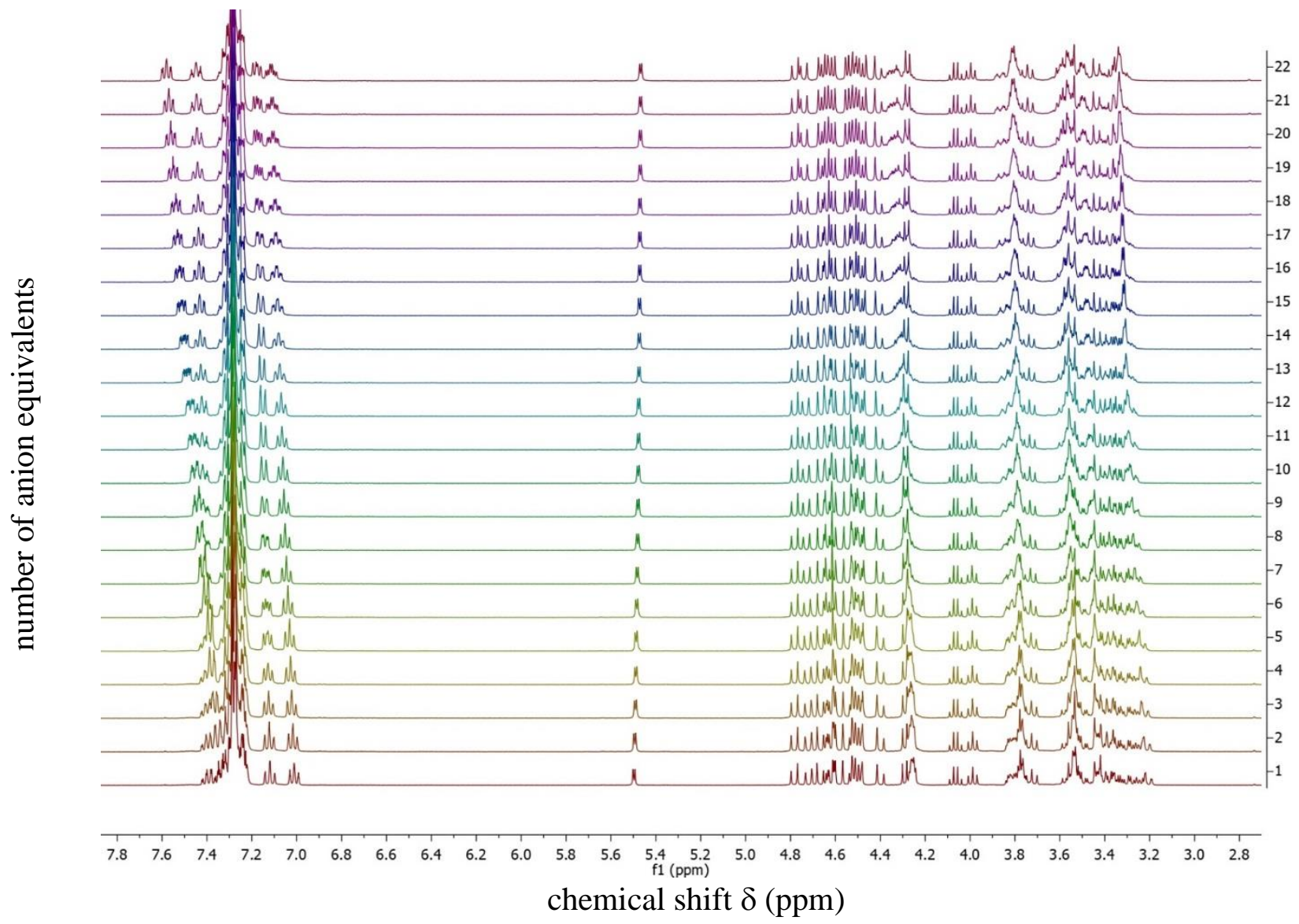

Fig. S9. Stacked plot from ${ }^{1} \mathrm{H}$ NMR titration of trans-1 with increasing amount of LiOTf (from bottom-to-top: $0.00,0.16,0.31,0.46,0.61,0.91,1.21,1.50,1.79,2.07,2.35,2.62,3.16,3.68,4.18$, $4.67,5.15,5.61,6.51,7.35,8.15,9.28)$

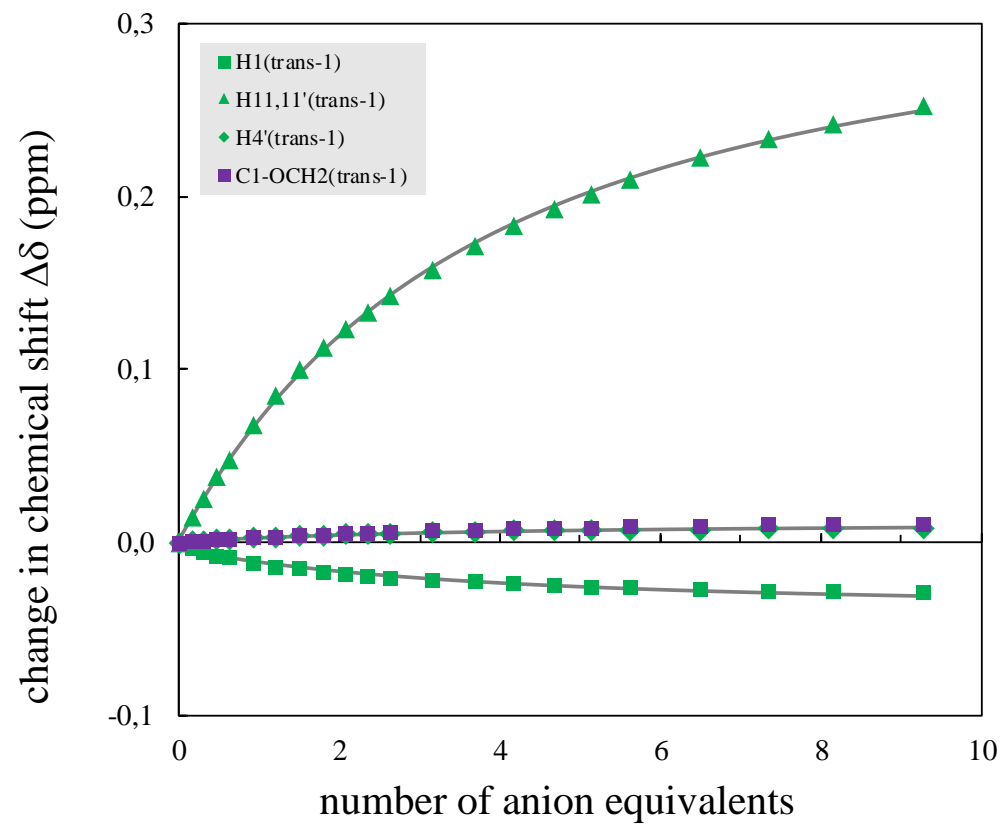

Fig. S10. Experimental chemical shift changes (symbols) and calculated binding isotherms (gray lines) for titration of trans-1 with LiOTf assuming 1:1 binding model; for proton labels see Section 2.7. 


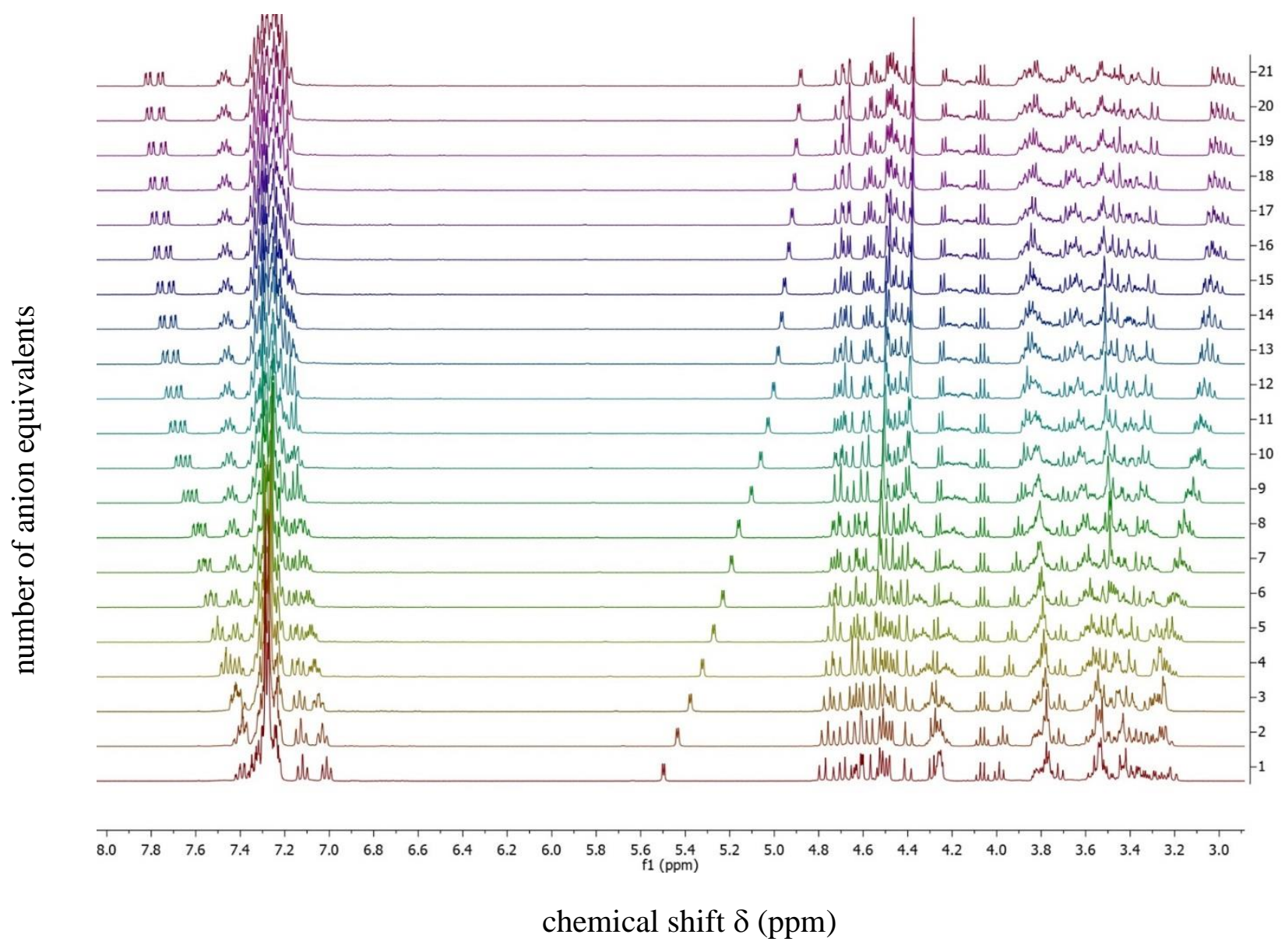

Fig. S11. Stacked plot from ${ }^{1} \mathrm{H}$ NMR titration of trans-1 with increasing amount of NaOTf (from bottom-to-top: $0.00,0.15,0.31,0.46,0.61,0.76,0.91,1.06,1.35,1.64,1.92,2.20,2.47,2.74,3.01$, $3.53,4.03,4.52,5.00,5.92,6.79)$.

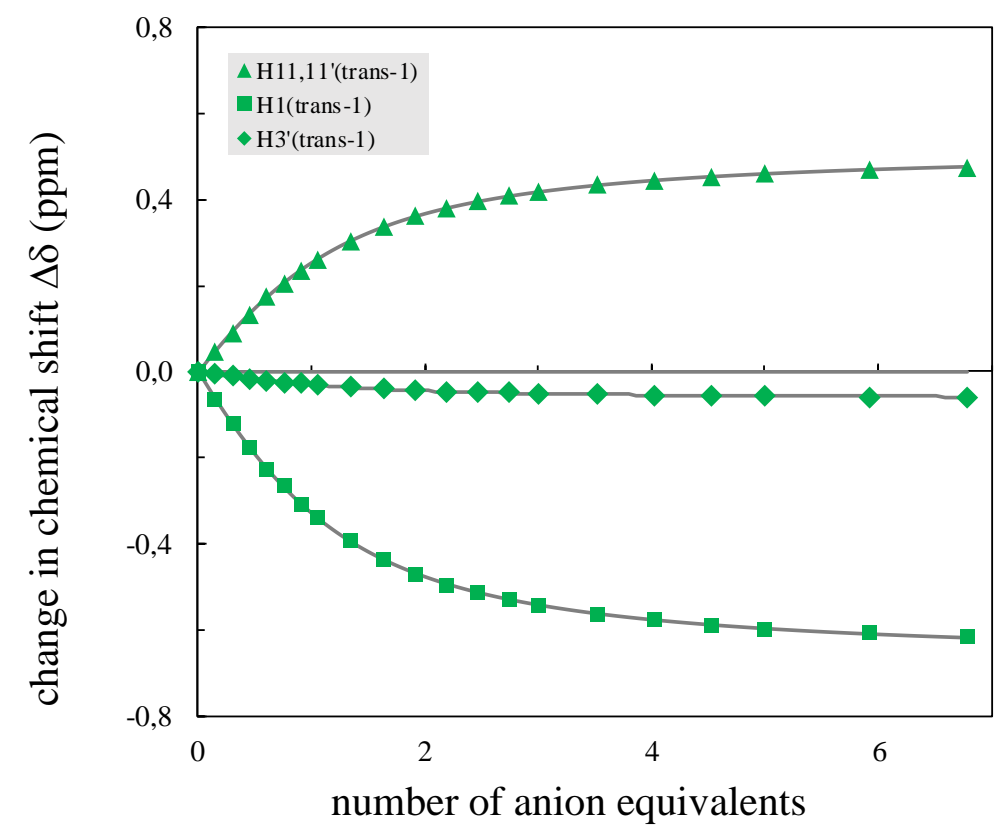

Fig. S12. Experimental chemical shift changes (symbols) and calculated binding isotherms (gray lines) for titration of trans-1 with NaOTf assuming 1:1 binding model; for proton labels see Section 2.7. 


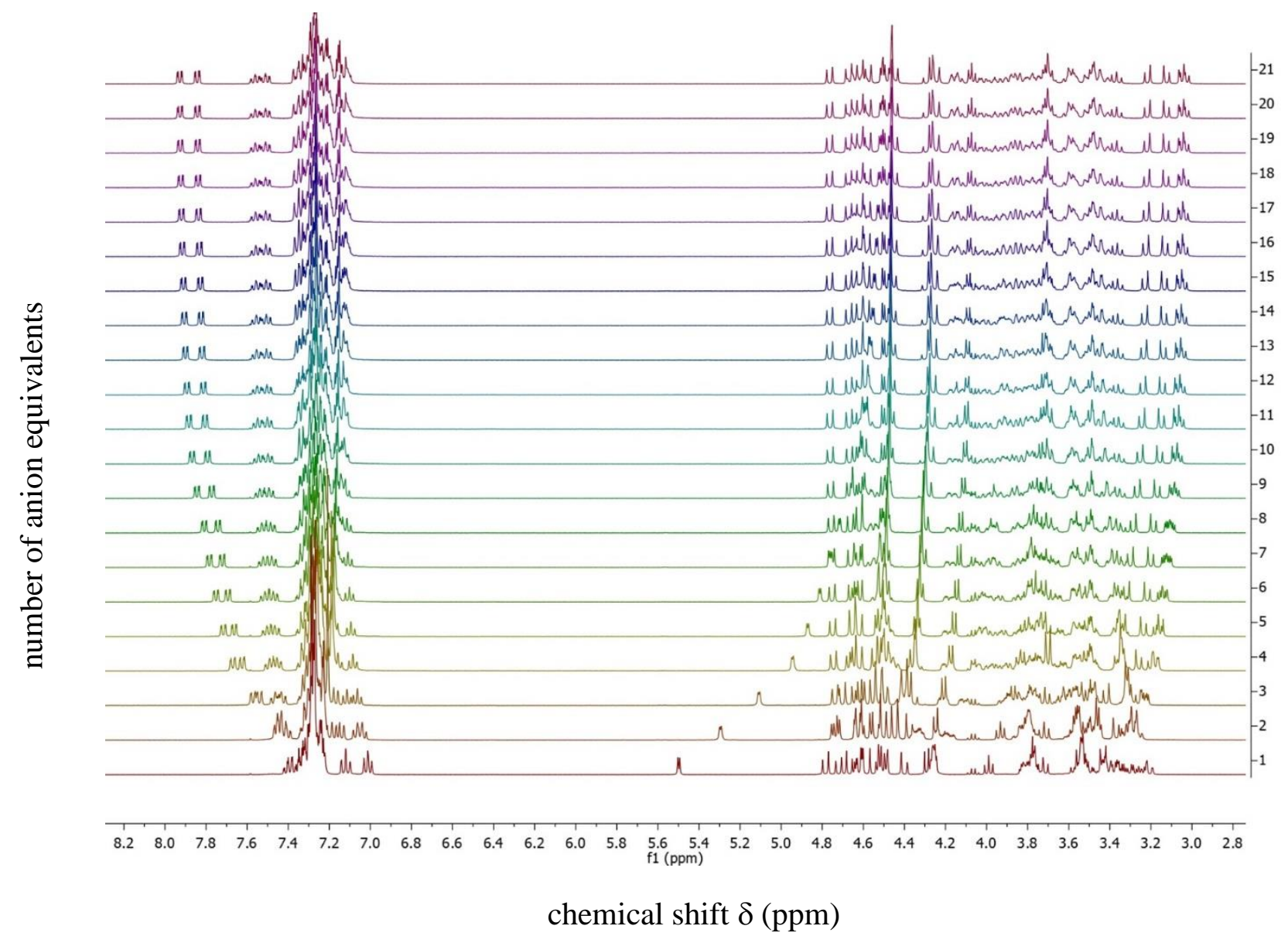

Fig. S13. Stacked plot from ${ }^{1} \mathrm{H}$ NMR titration of trans-1 with increasing amount of KOTf (from bottom-to-top: $0.00,0.23,0.47,0.69,0.81,0.92,1.03,1.14,1.35,1.57,1.78,1.99,2.19,2.39,2.59,2.98$, $3.35,3.72,4.08,4.42,4.76)$.

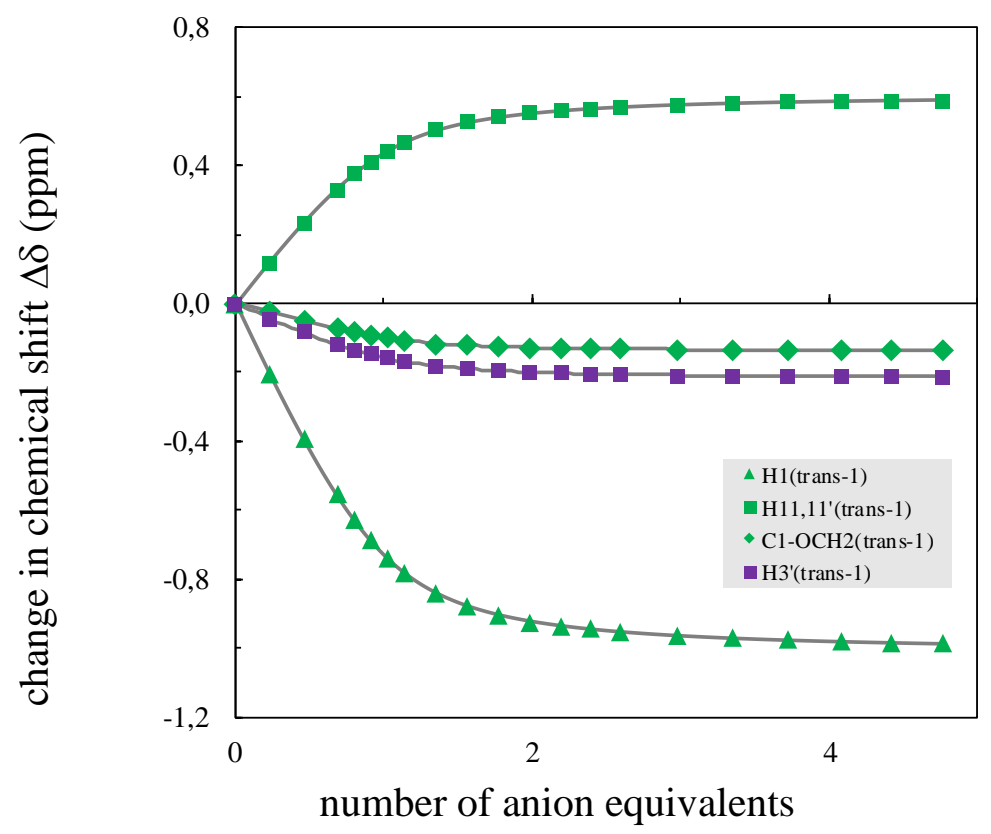

Fig. S14. Experimental chemical shift changes (symbols) and calculated binding isotherms (gray lines) for titration of trans-1 with KOTf assuming 1:1 binding model; for proton labels see Section 2.7. 


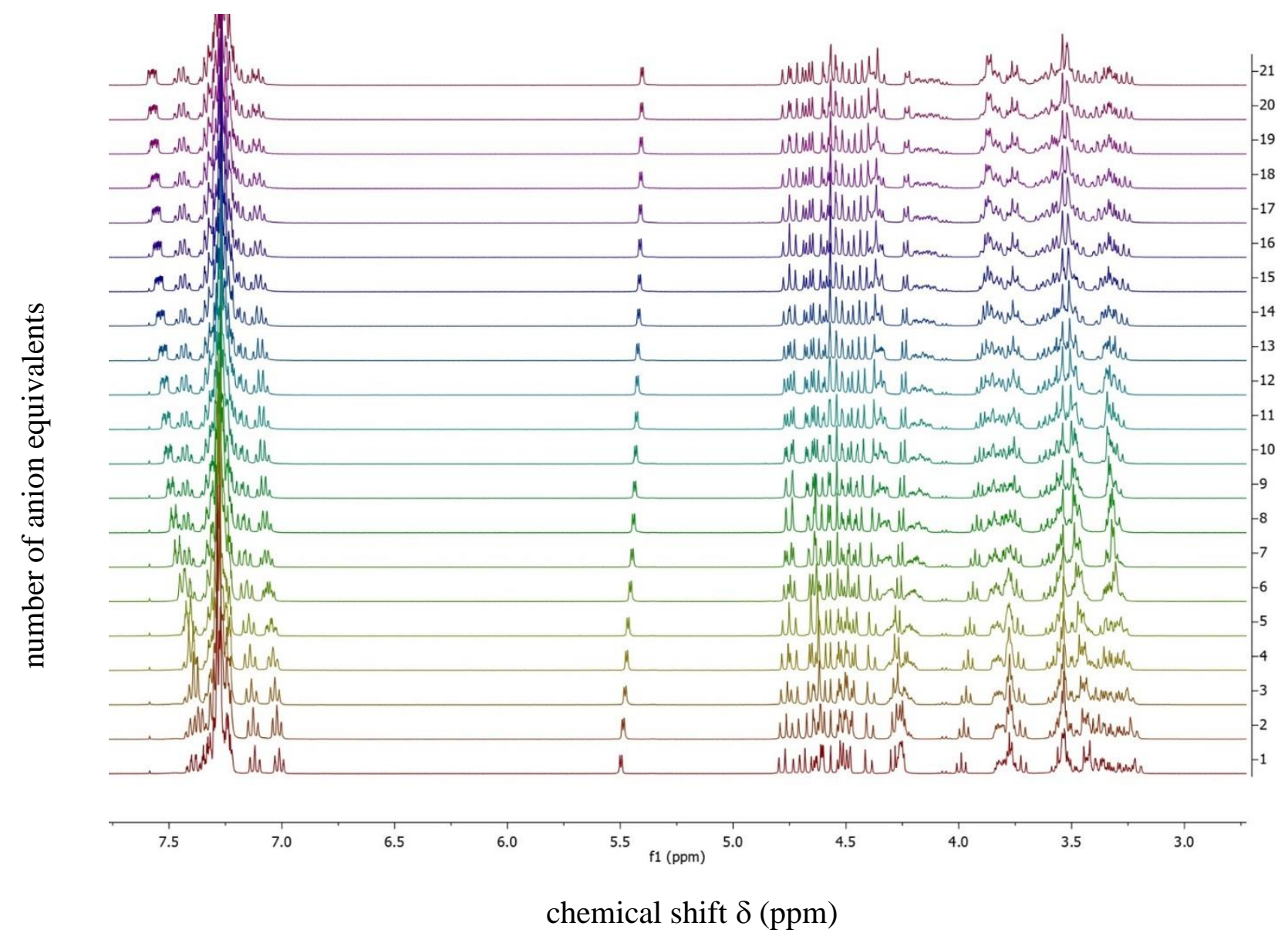

Fig. S15. Stacked plot from ${ }^{1} \mathrm{H}$ NMR titration of trans-1 with increasing amount of CsOTf (from bottom-to-top: $0.00,0.18,0.36,0.53,0.71,1.05,1.39,1.73,2.06,2.39,2.71,3.02,3.33,3.94,4.53$, $5.10,5.66,6.20,6.73,7.75,8.71)$.

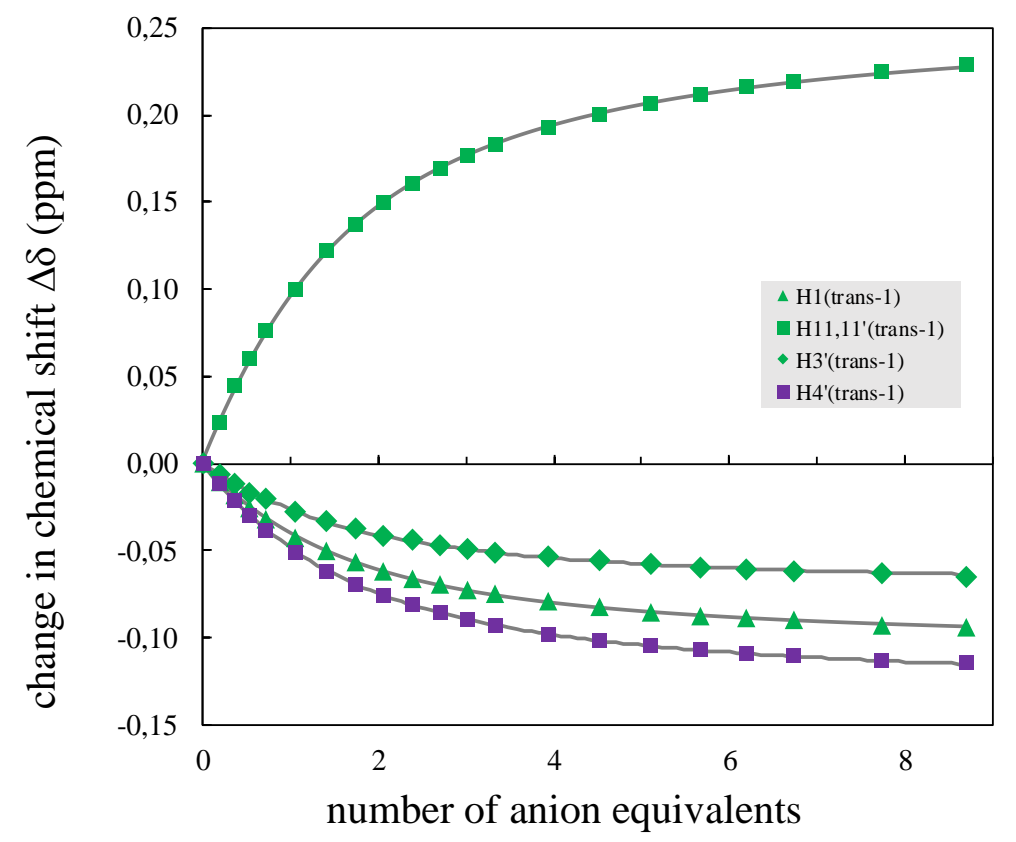

Fig. S16. Experimental chemical shift changes (symbols) and calculated binding isotherms (gray lines) for titration of trans $\mathbf{- 1}$ with CsOTf assuming 1:1 binding model; for proton labels see Section 2.7. 


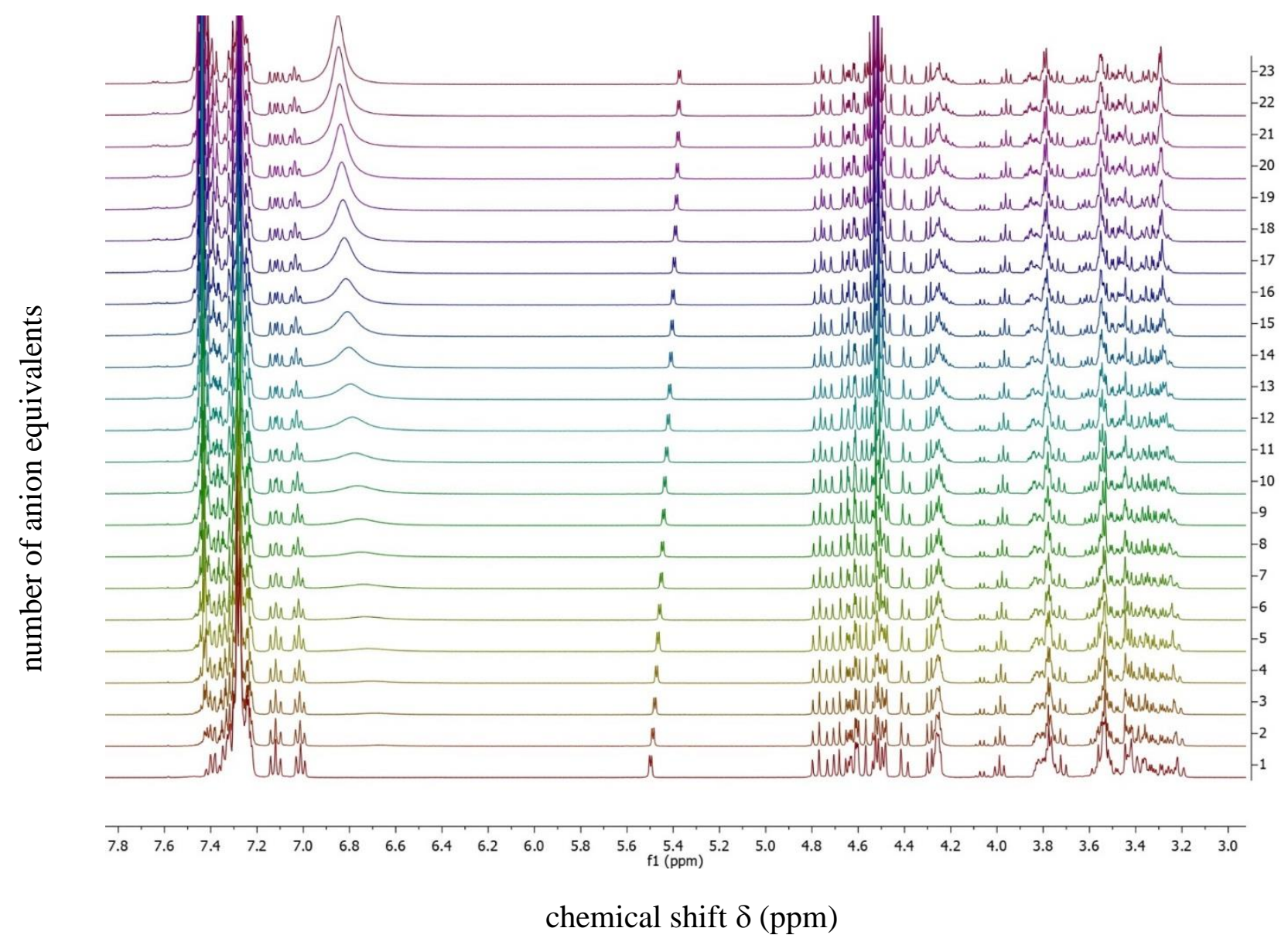

Fig. S17. Stacked plot from ${ }^{1} \mathrm{H}$ NMR titration of trans-1 with increasing amount of (S)-PEA-TfOH (from bottom-to-top: 0.00, 0.19, 0.38, 0.57, 0.75, 0.93, 1.11, 1.45, 1.79, 2.12, 2.44, 2.74, 3.04, 3.62, $4.16,4.68,5.17,5.64,6.30,6.91,7.48,8.02)$.

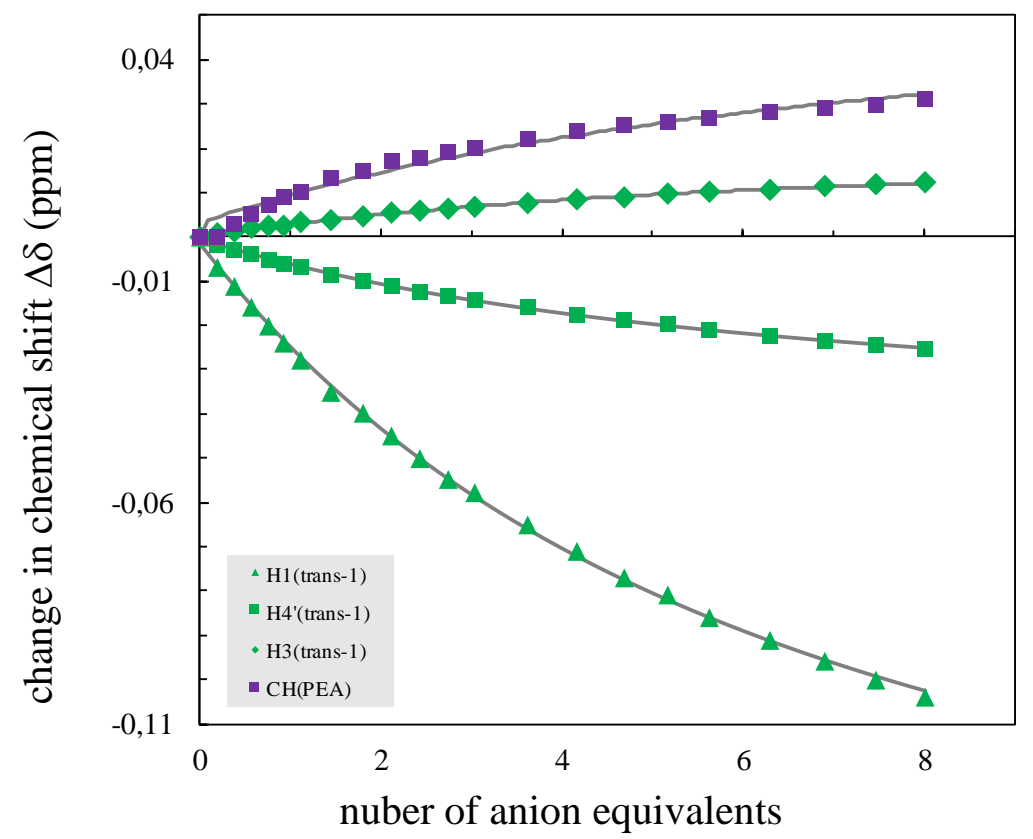

Fig. S18. Experimental chemical shift changes (symbols) and calculated binding isotherms (gray lines) for titration of trans-1 with (S)-PEA-TfOH assuming 1:1 binding model; for proton labels see section 2.7 . 


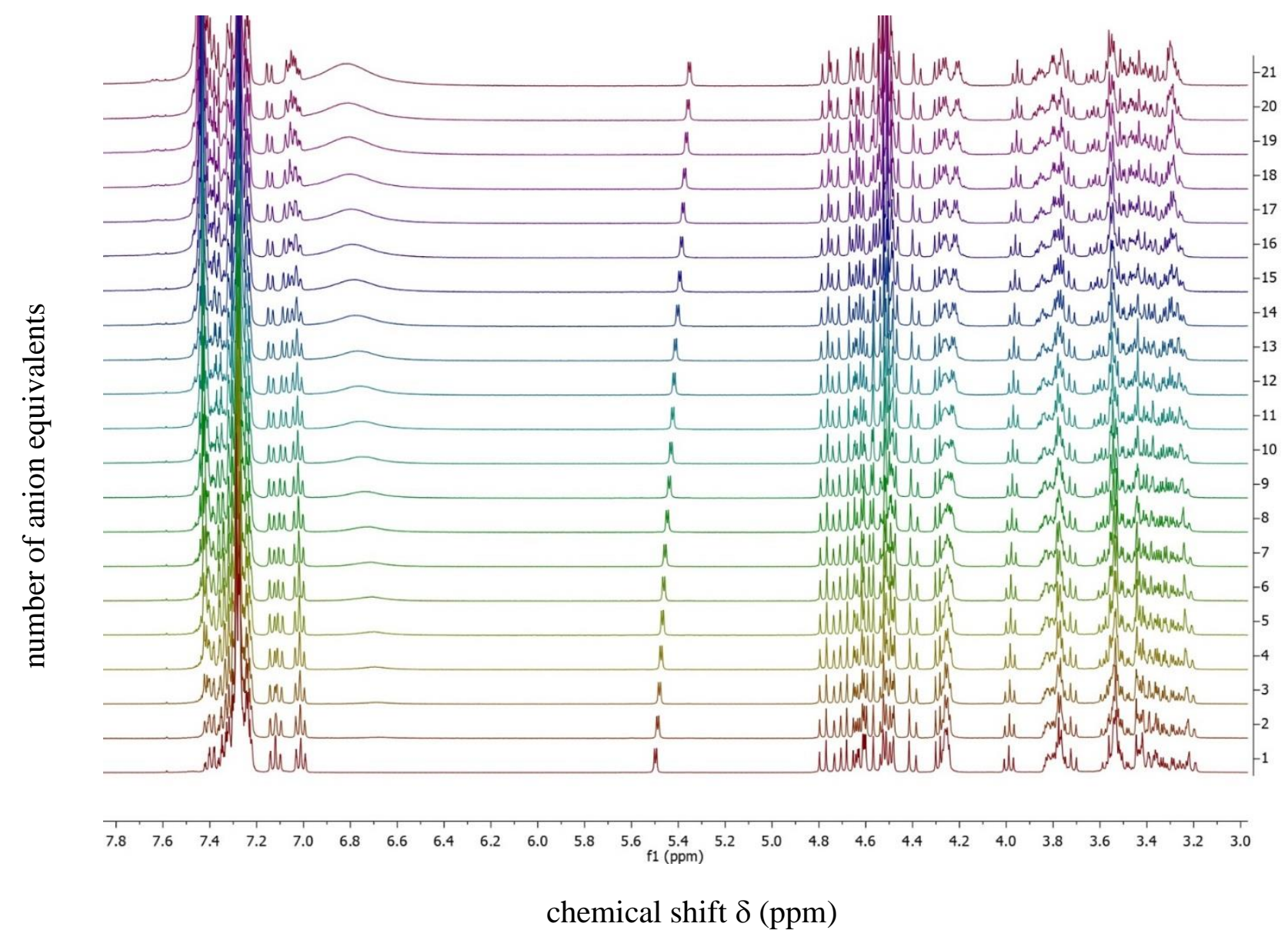

Fig. S19. Stacked plot from ${ }^{1} \mathrm{H}$ NMR titration of trans-1 with increasing amount of (R)-PEA-TfOH (from bottom-to-top: 0.00, 0.19, 0.37, 0.55, 0.73, 0.91, 1.08, 1.42, 1.75, 2.07, 2.38, 2.68, 2.97, 3.53, $4.06,4.57,5.04,5.50,6.14,6.74,7.30)$.

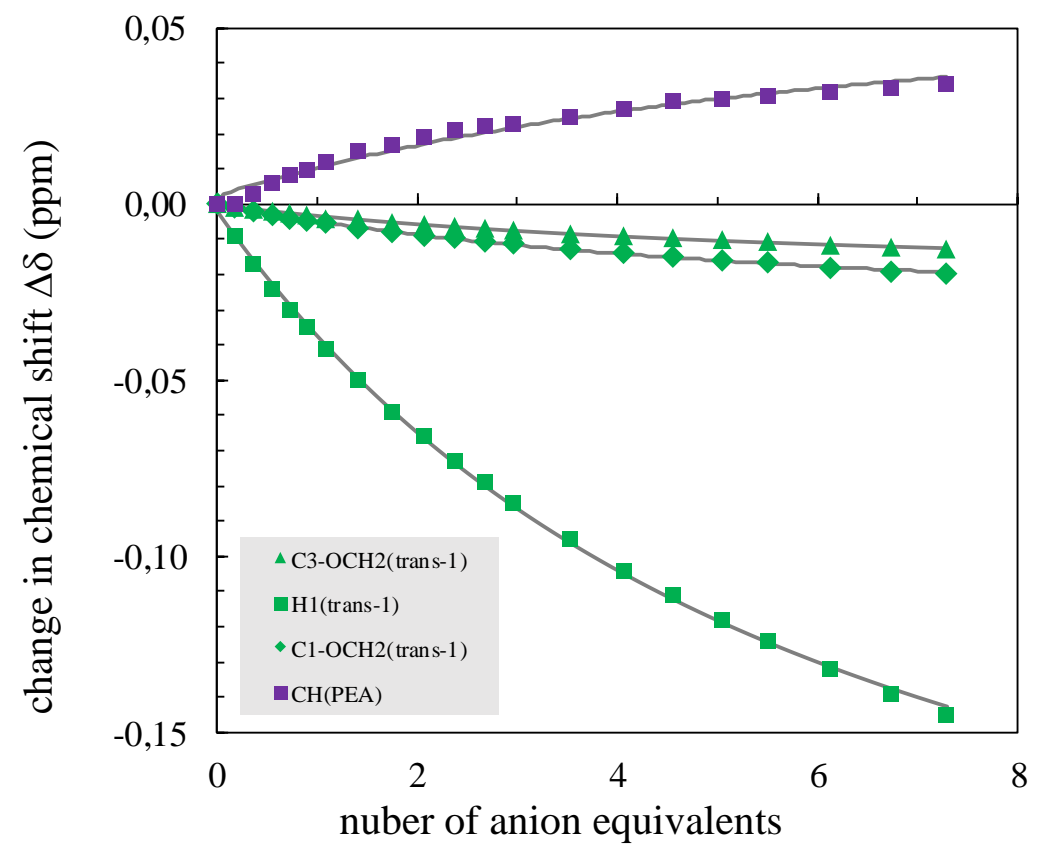

Fig. S20. Experimental chemical shift changes (symbols) and calculated binding isotherms (gray lines) for titration of trans-1 with (R)-PEA-TfOH assuming 1:1 binding model; for proton labels see section 2.7 . 


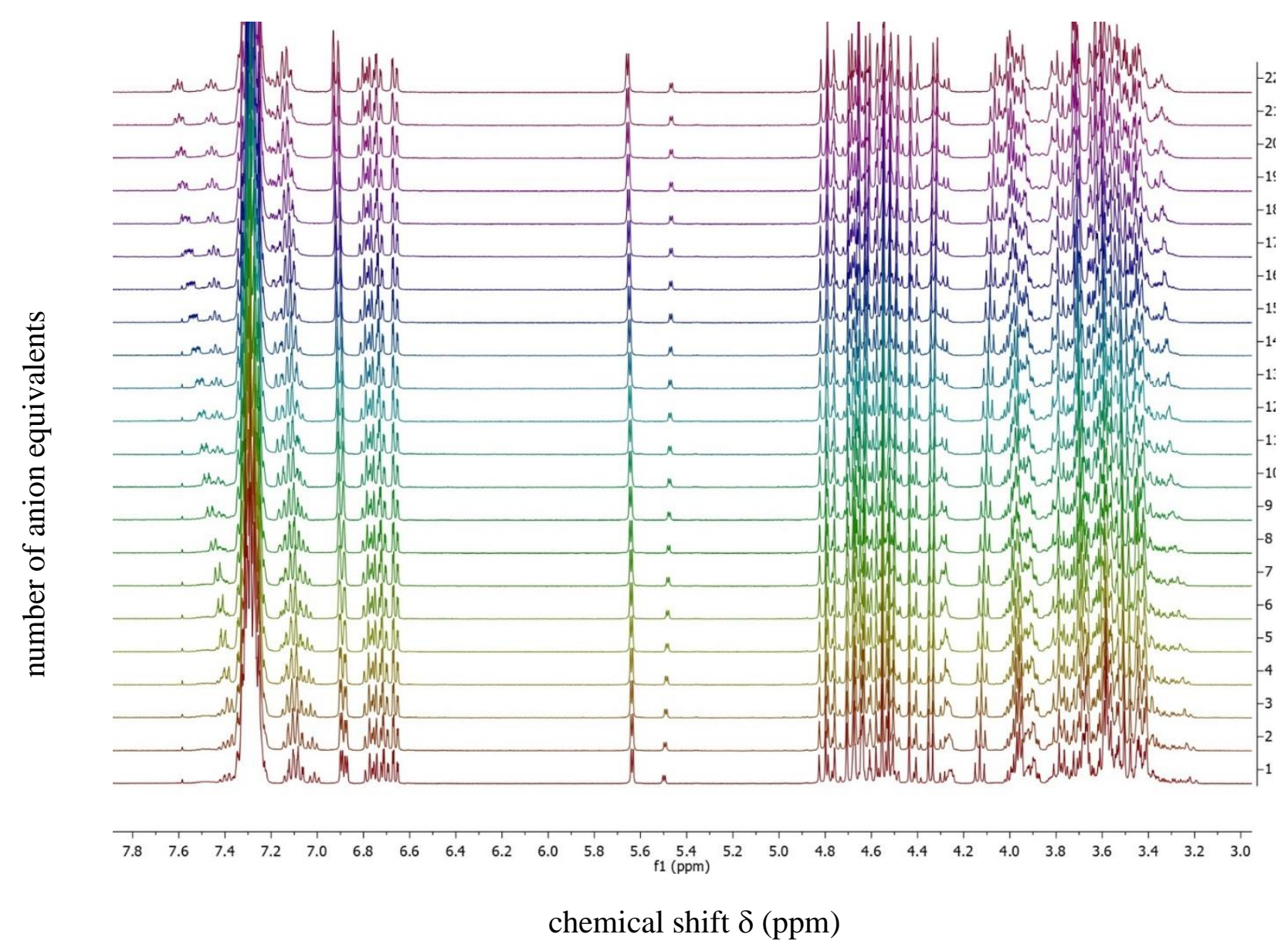

Fig. S21. Stacked plot from ${ }^{1} \mathrm{H}$ NMR titration of cis-1 with increasing amount of LiOTf (from bottom-to-top: $0.00,0.16,0.32,0.48,0.64,0.80,0.96,1.27,1.57,1.87,2.16,2.46,2.74,3.30,3.85$, $4.37,4.89,5.87,6.80,7.69,8.53,9.32)$.

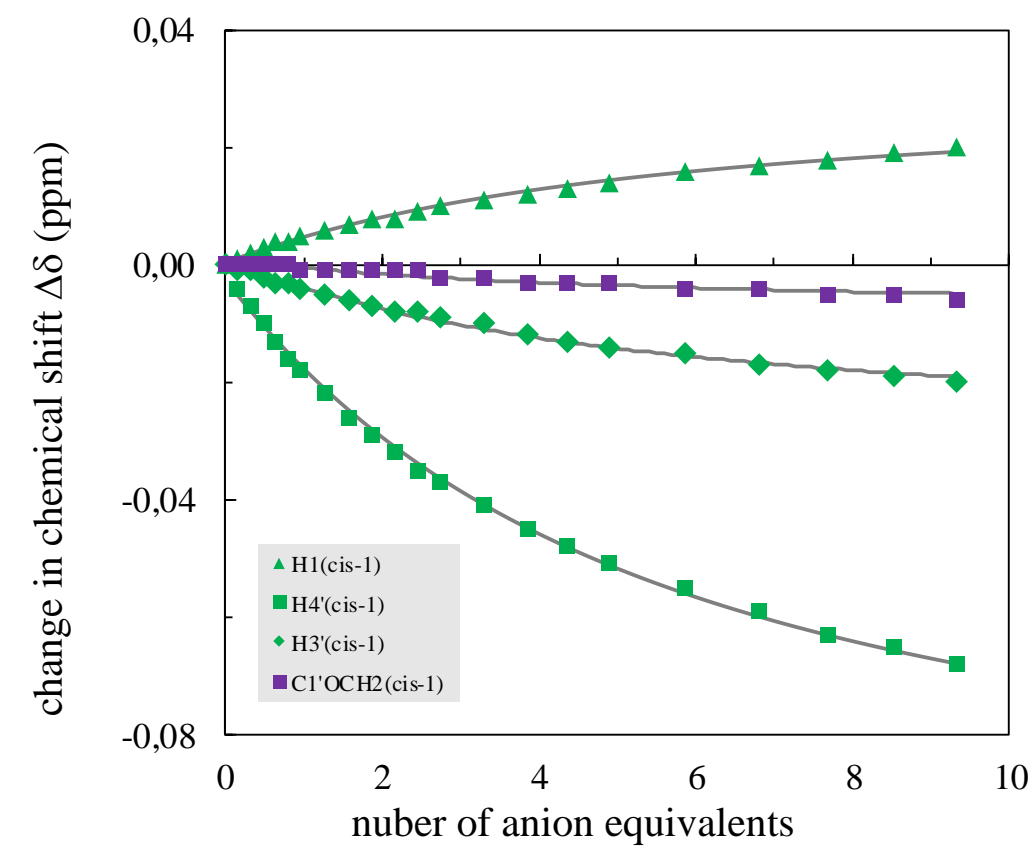

Fig. S22. Experimental chemical shift changes (symbols) and calculated binding isotherms (gray lines) for titration of cis-1 with LiOTf assuming 1:1 binding model; for proton labels see Section 2.8. 


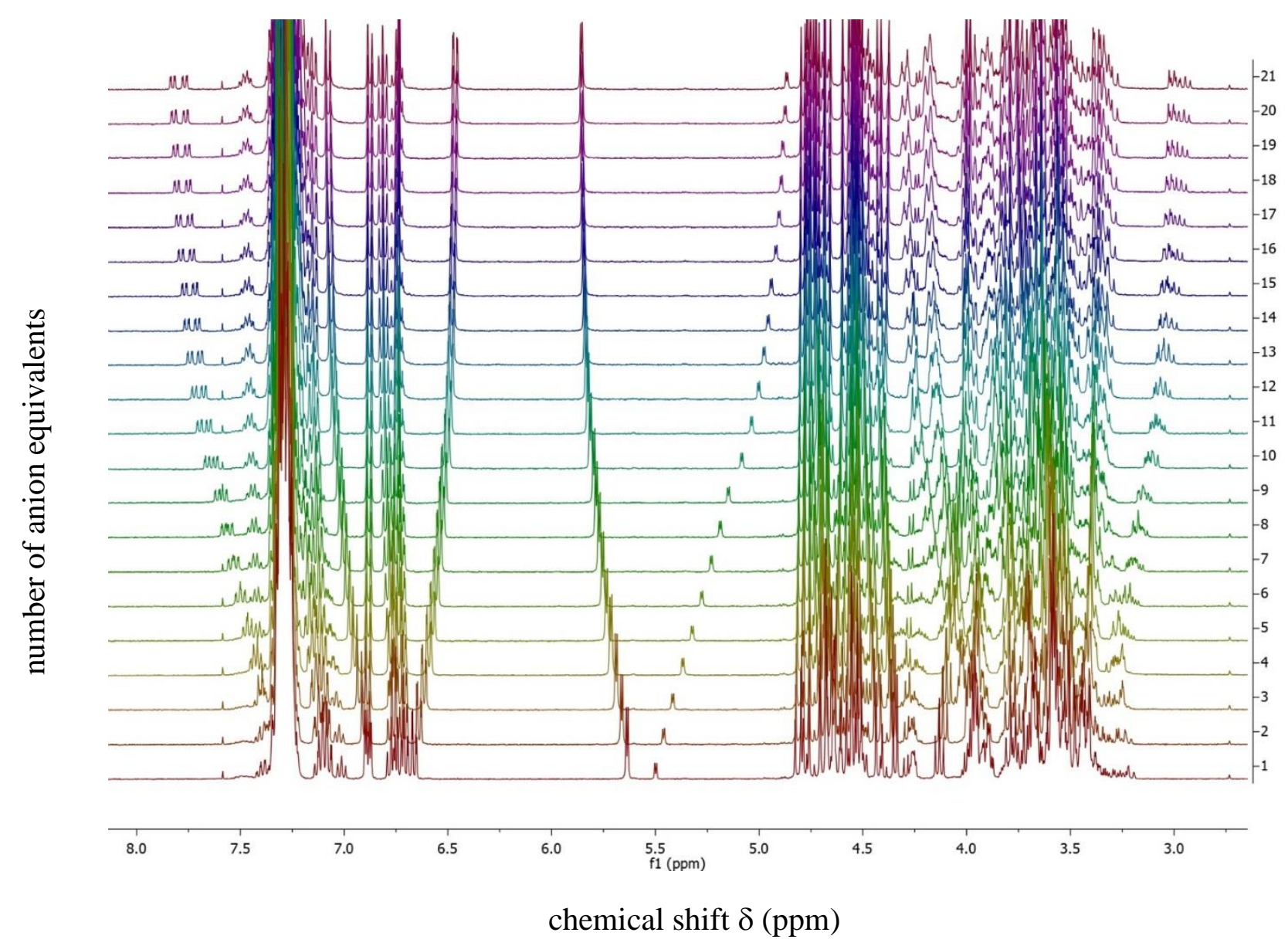

Fig. S23. Stacked plot from ${ }^{1} \mathrm{H}$ NMR titration of cis-1 with increasing amount of NaOTf (from bottom-to-top: $0.00,0.13,0.27,0.40,0.53,0.66,0.78,0.91,1.04,1.29,1.53,1.77,2.01,2.25,2.48$, $2.93,3.37,3.79,4.21,5.00,5.76)$.

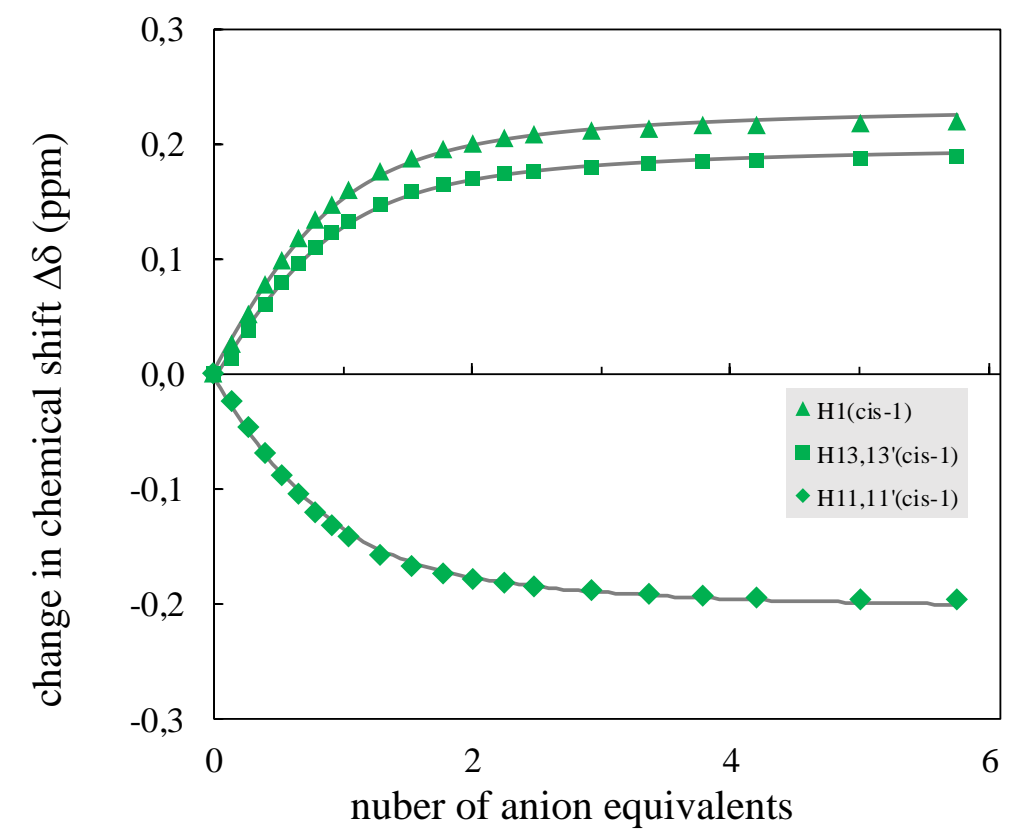

Fig. S24. Experimental chemical shift changes (symbols) and calculated binding isotherms (gray lines) for titration of cis-1 with NaOTf assuming 1:1 binding model; for proton labels see Section 2.8. 


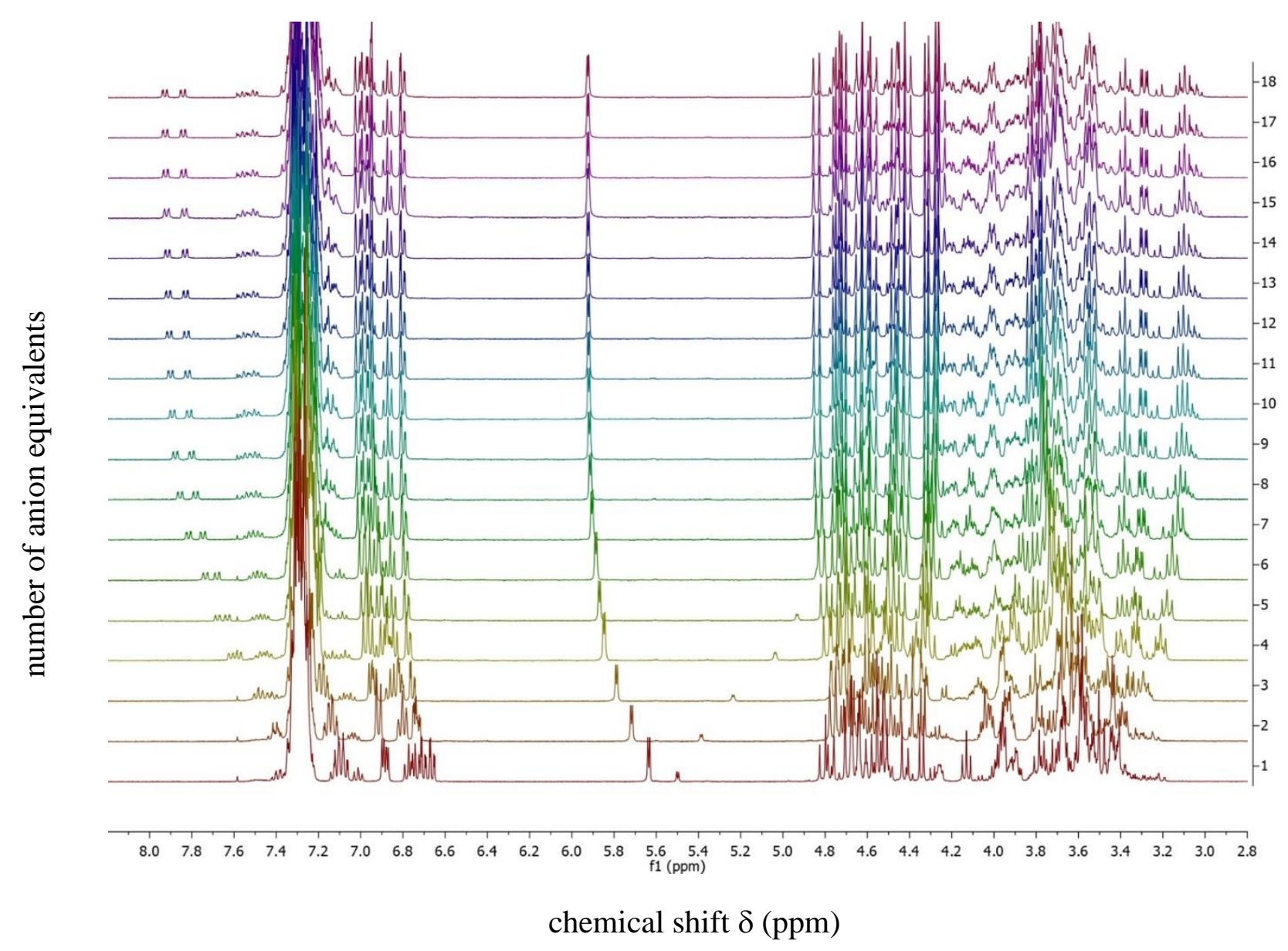

Fig. S25. Stacked plot from ${ }^{1} \mathrm{H}$ NMR titration of $\mathrm{cis}$-1 with increasing amount of KOTf (from bottom-to-top: $0.00,0.24,0.47,0.69,0.81,0.92,1.14,1.36,1.57,1.78,1.99,2.20,2.40,2.60,2.99$, $3.36,3.73,4.09)$.

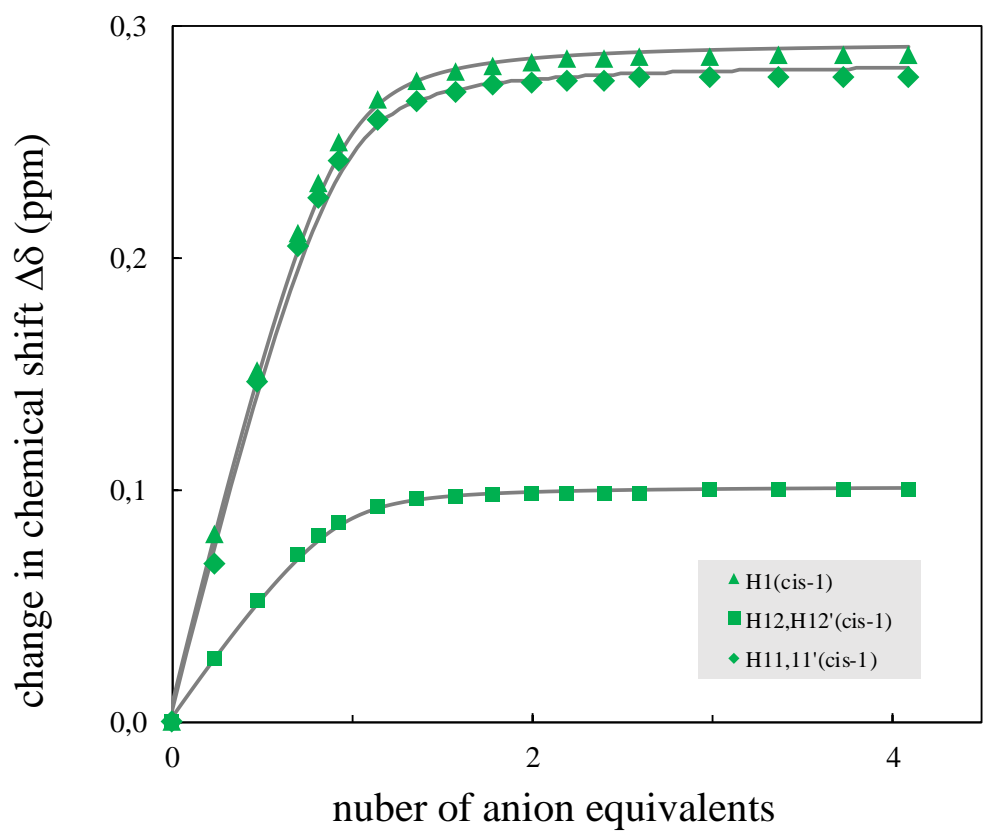

Fig. S26. Experimental chemical shift changes (symbols) and calculated binding isotherms (gray lines) for titration of cis-1 with KOTf assuming 1:1 binding model; for proton labels see Section 2.8. 


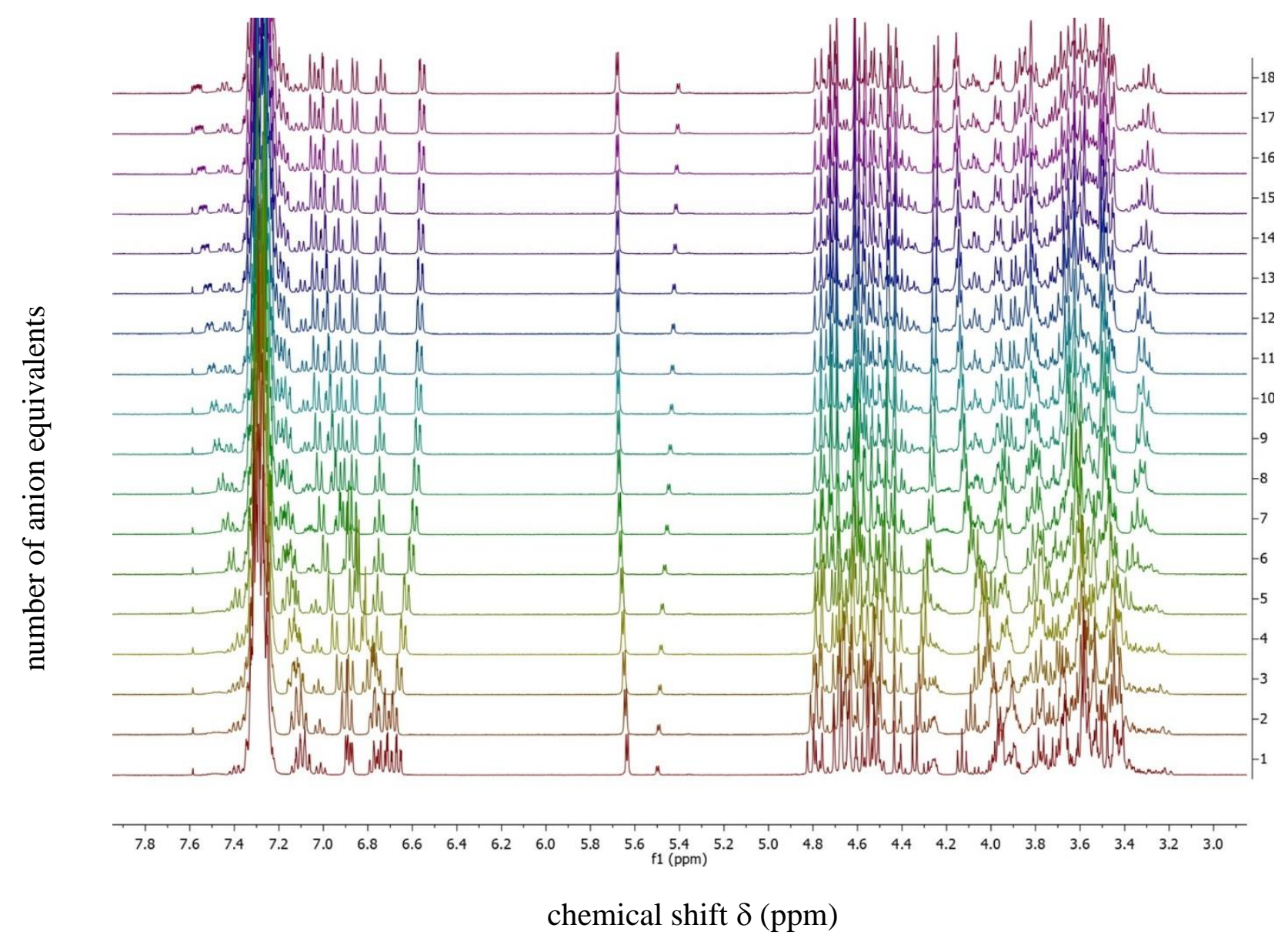

Fig. S27. Stacked plot from ${ }^{1} \mathrm{H}$ NMR titration of $\mathrm{cis}-\mathbf{1}$ with increasing amount of CsOTf (from bottom-to-top: $0.00,0.18,0.35,0.53,0.70,1.04,1.37,1.70,2.03,2.35,2.66,2.97,3.28,3.88,4.46,5.03$, $6.11,7.13)$.

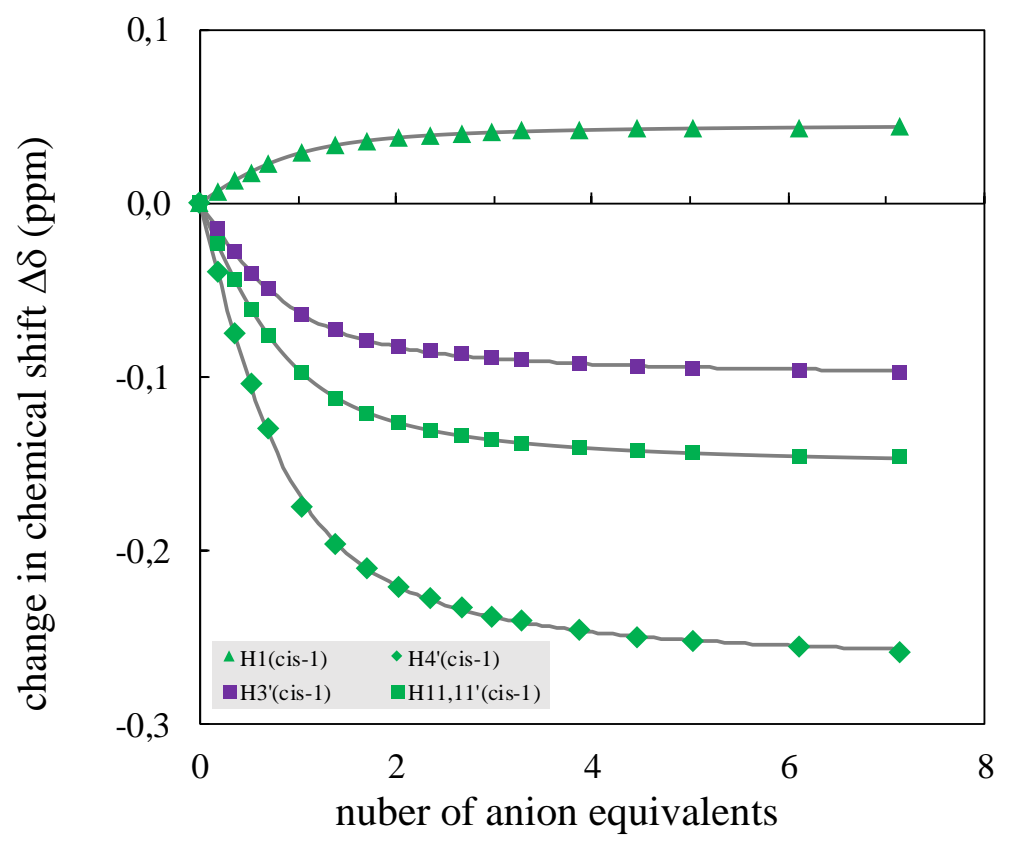

Fig. S28. Experimental chemical shift changes (symbols) and calculated binding isotherms (gray lines) for titration of cis-1 with CsOTf assuming 1:1 binding model; for proton labels see Section 2.8. 


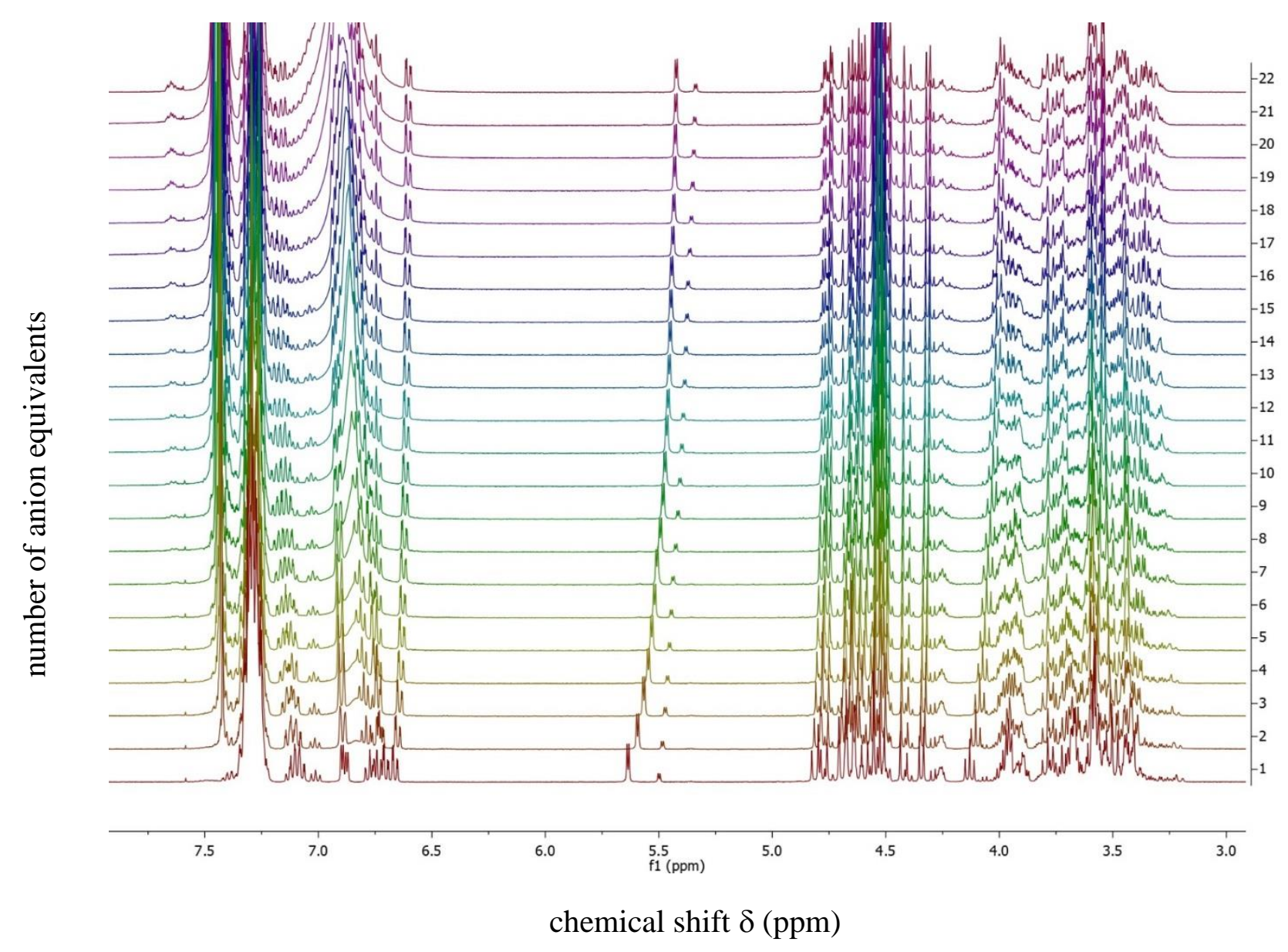

Fig. S29. Stacked plot from ${ }^{1} \mathrm{H}$ NMR titration of cis-1 with increasing amount of (S)-PEA-TfOH (from bottom-to-top: 0.00, 0.66, 1.31, 1.96, 2.59, 3.21, 3.82, 5.02, 6.18, 7.31, 8.40, 9.47, 10.50, $11.51,12.49,13.44,15.27,17.00,18.65,20.22,21.72,23.15)$.

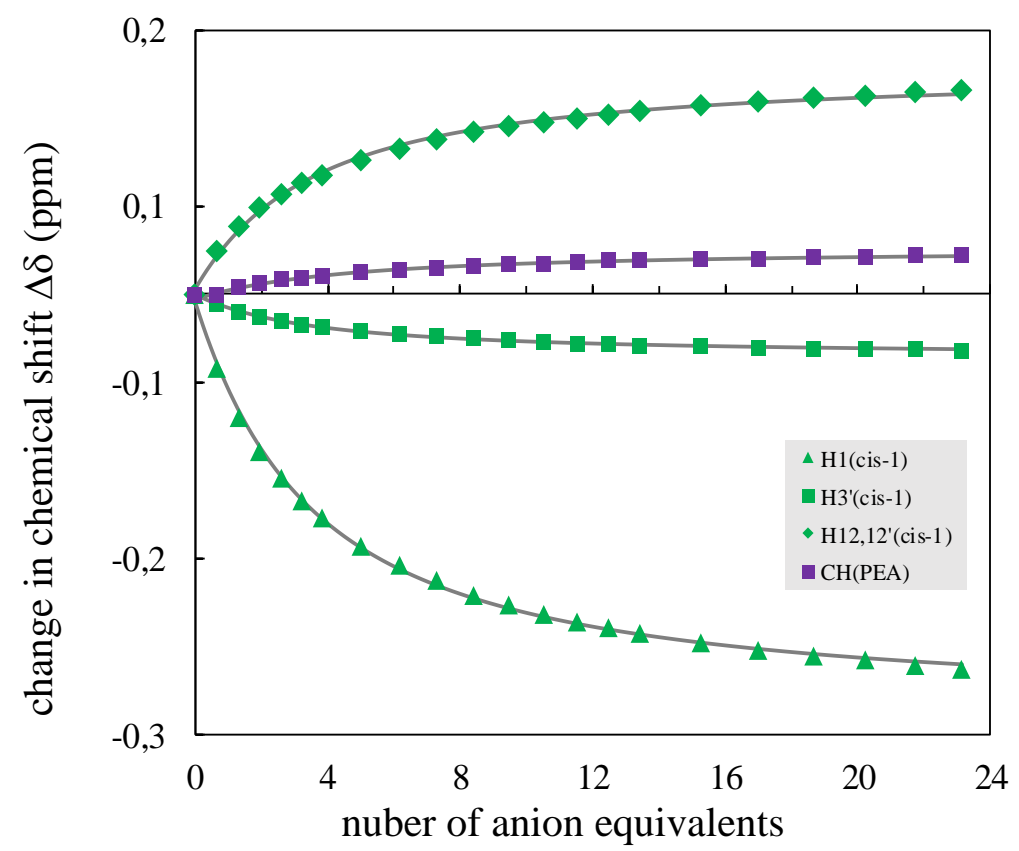

Fig. S30. Experimental chemical shift changes (symbols) and calculated binding isotherms (gray lines) for titration of cis-1 with (S)-PEA-TfOH assuming 1:1 binding model; for proton labels see section 2.8 . 


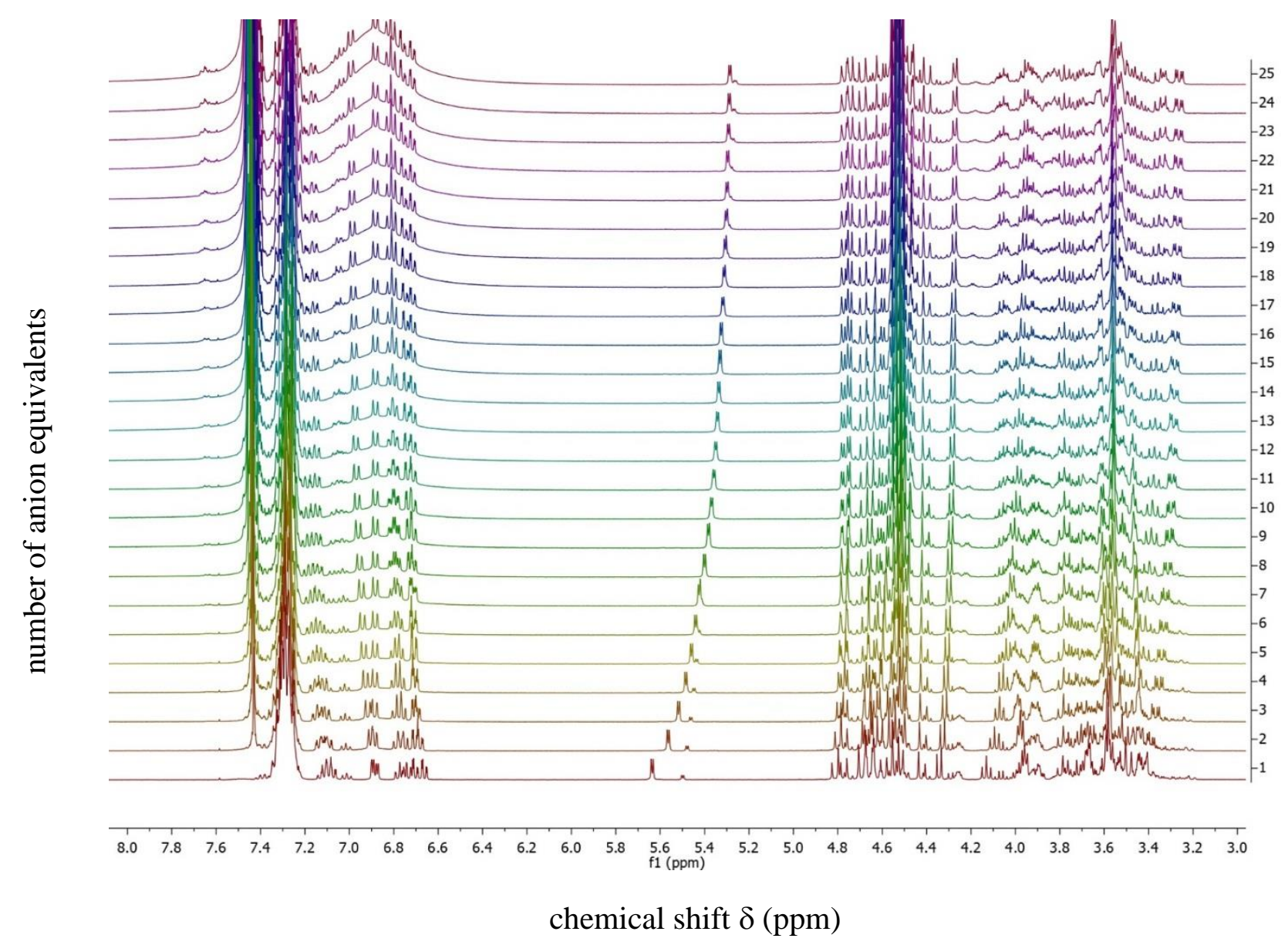

Fig. S31. Stacked plot from ${ }^{1} \mathrm{H}$ NMR titration of $c i s-1$ with increasing amount of (R)-PEA-TfOH (from bottom-to-top: 0.00, 0.64, 1.27, 1.89, 2.51, 3.11, 3.70, 4.86, 5.99, 7.08, 8.14, 9.17, 10.18, $11.15,12.10,13.02,14.79,16.48,18.08,19.60,21.05,22.43,24.39,26.22,27.93)$.

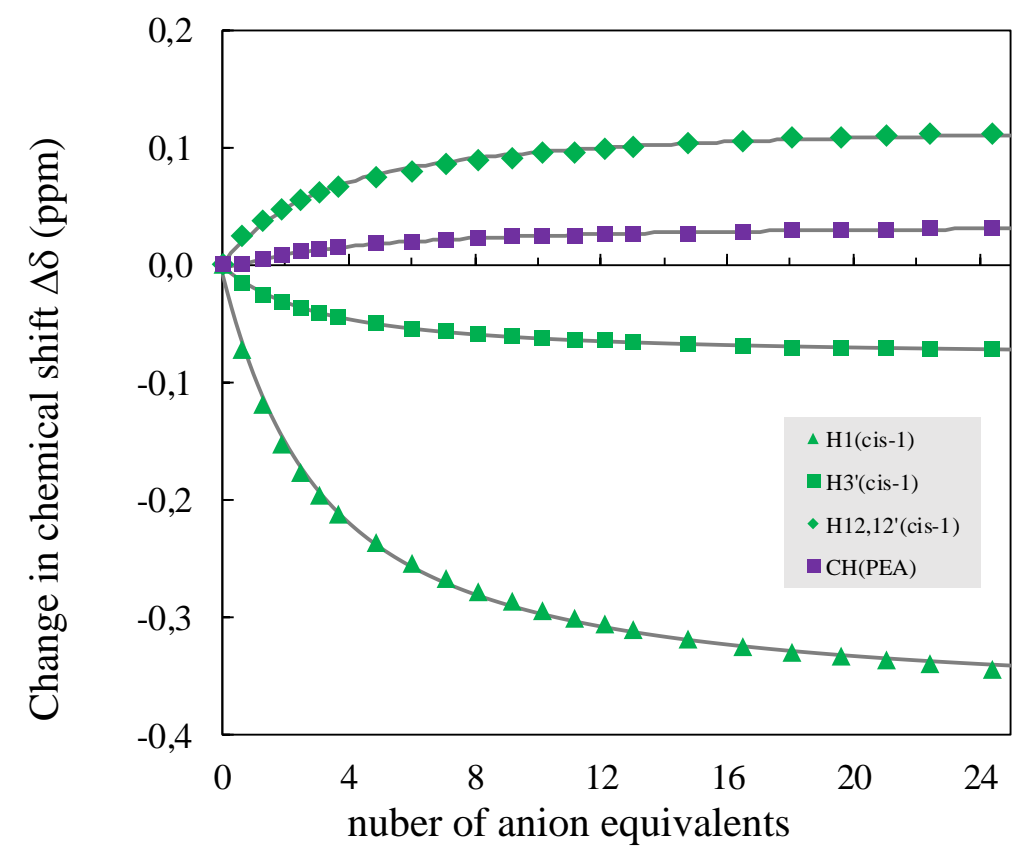

Fig. S32. Experimental chemical shift changes (symbols) and calculated binding isotherms (gray lines) for titration of cis-1 with (R)-PEA-TfOH assuming 1:1 binding model; for proton labels see section 2.8 . 


\section{Copies of the NMR spectra}

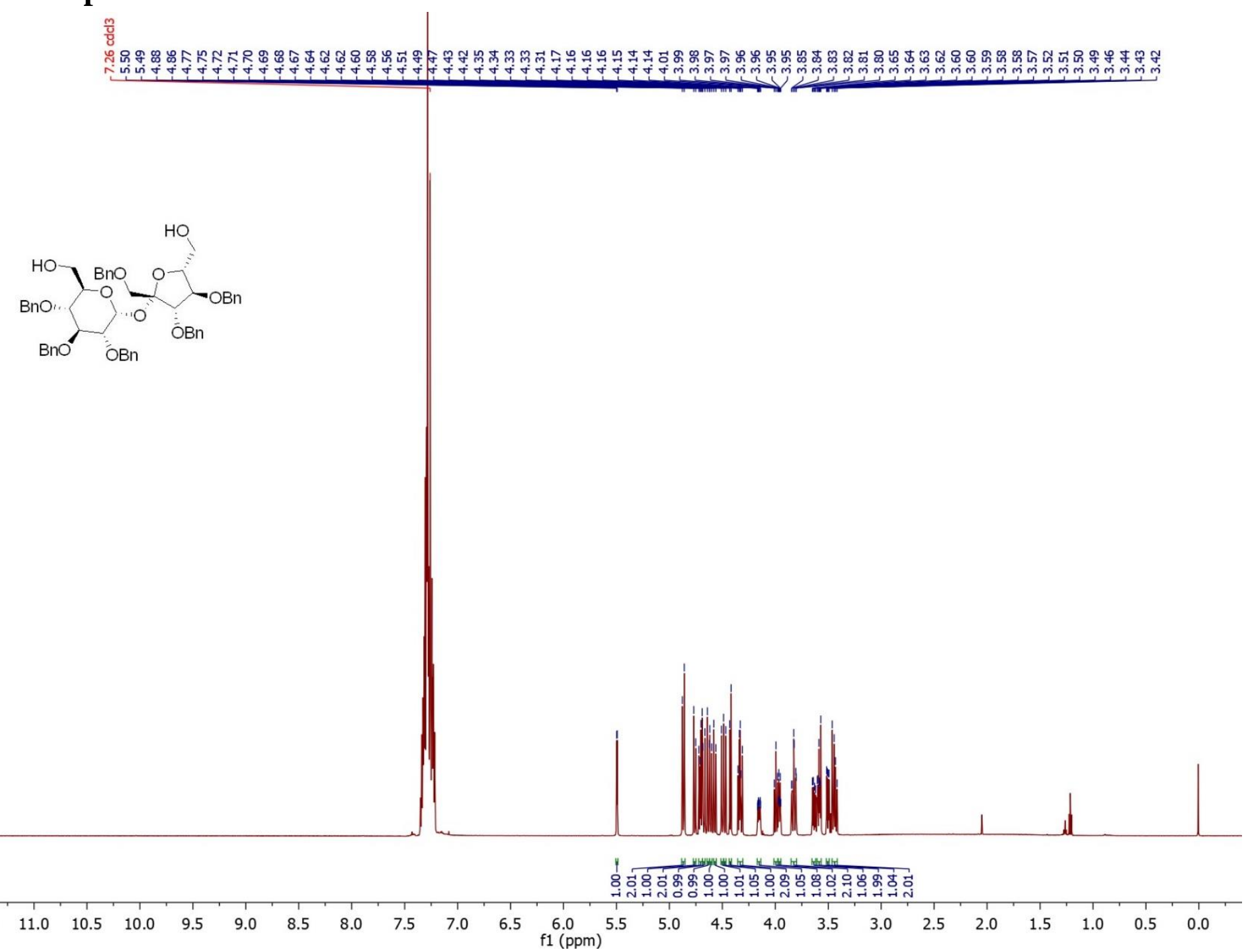

Figure S33. ${ }^{1} \mathrm{H}$ NMR $\left(600 \mathrm{MHz}, \mathrm{CDCl}_{3}\right)$ spectrum of compound 5. 
嘿照盟

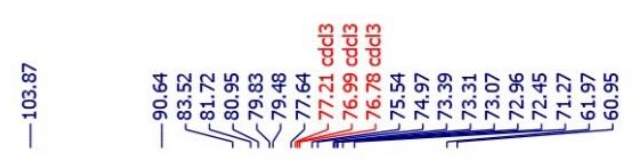
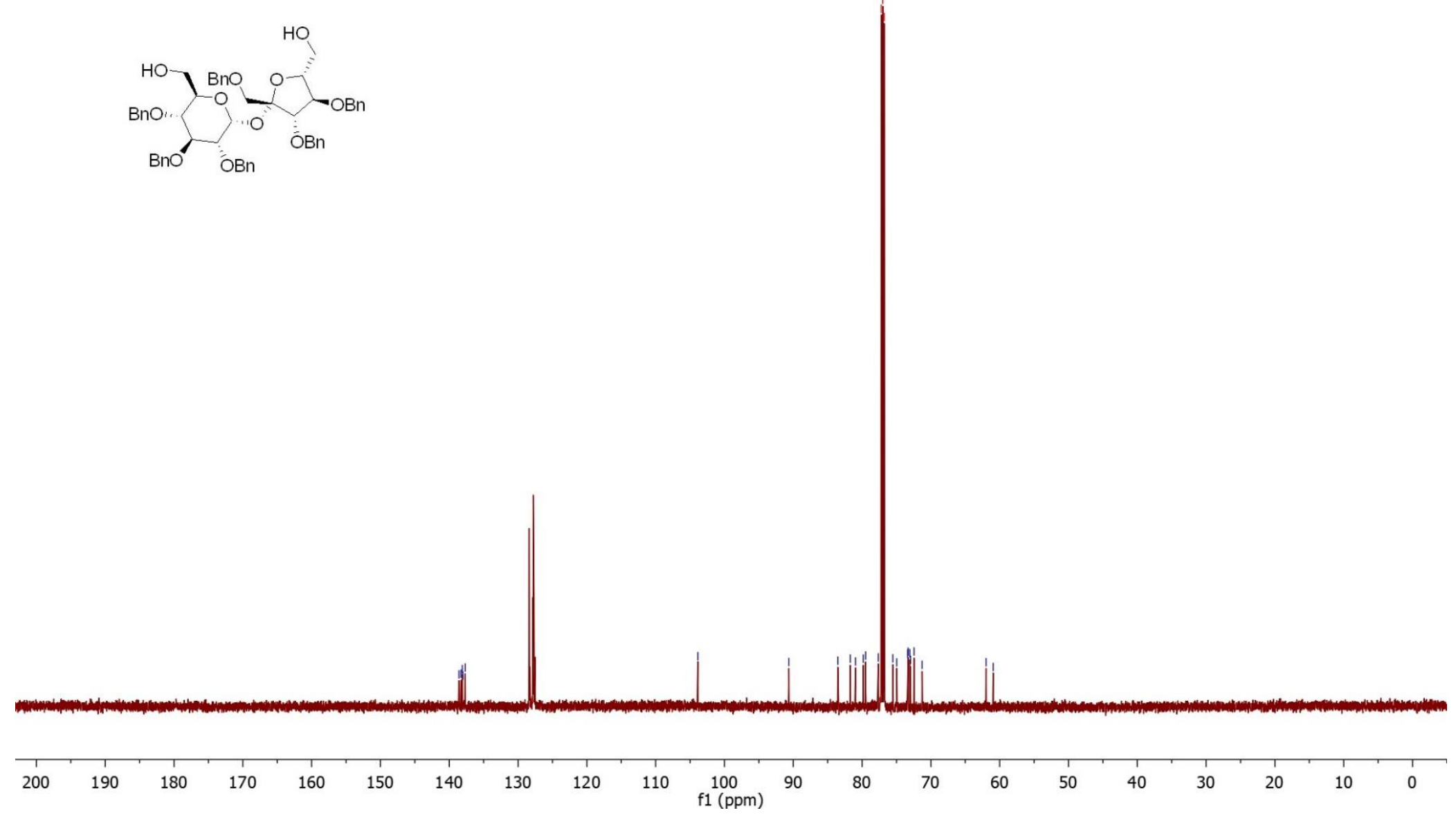

Figure S34. ${ }^{13} \mathrm{C}$ NMR $\left(151 \mathrm{MHz}, \mathrm{CDCl}_{3}\right)$ spectrum of compound 5.

S30 

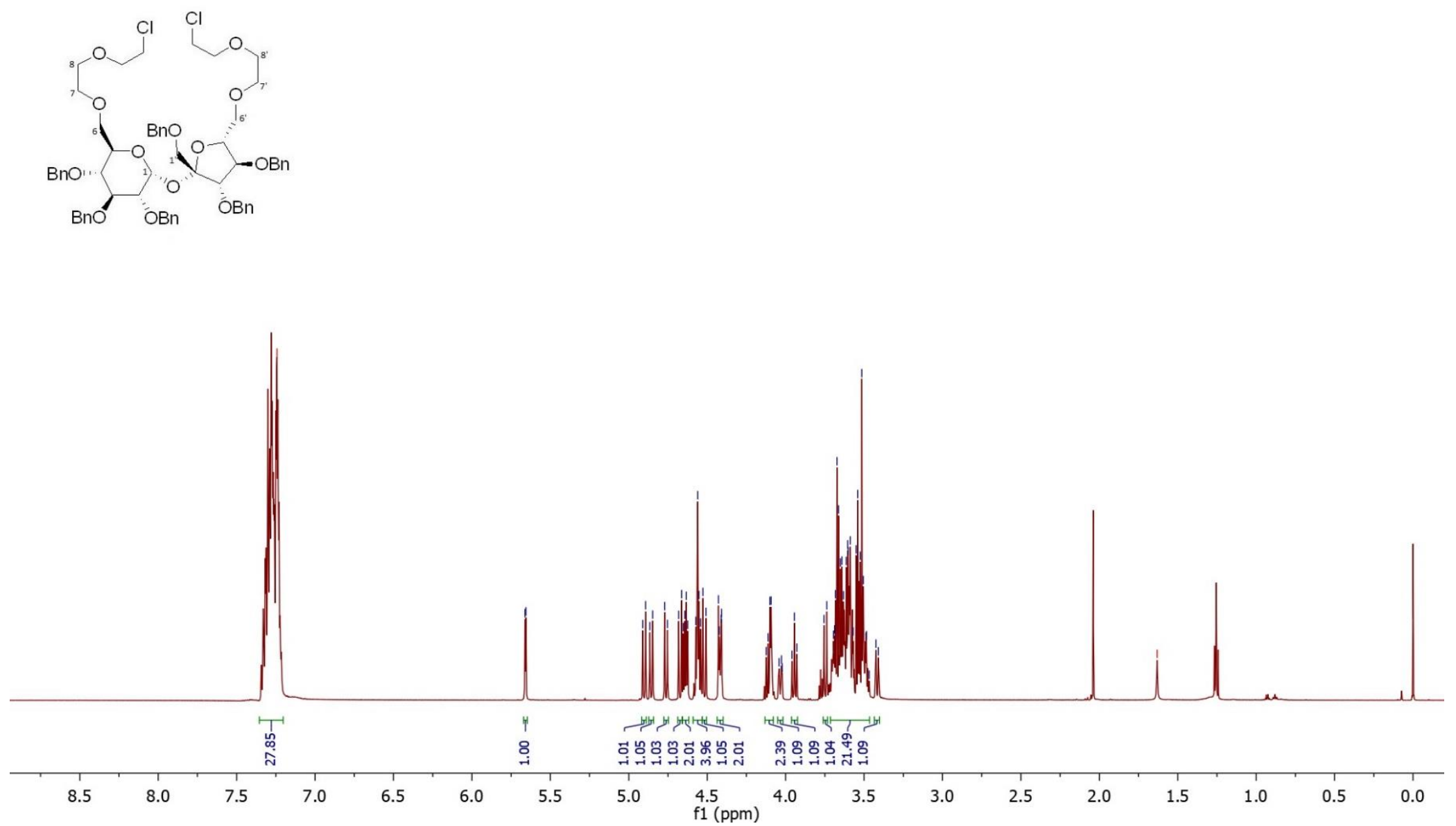

Figure S35. ${ }^{1} \mathrm{H}$ NMR $\left(600 \mathrm{MHz}, \mathrm{CDCl}_{3}\right)$ spectrum of compound 6. 

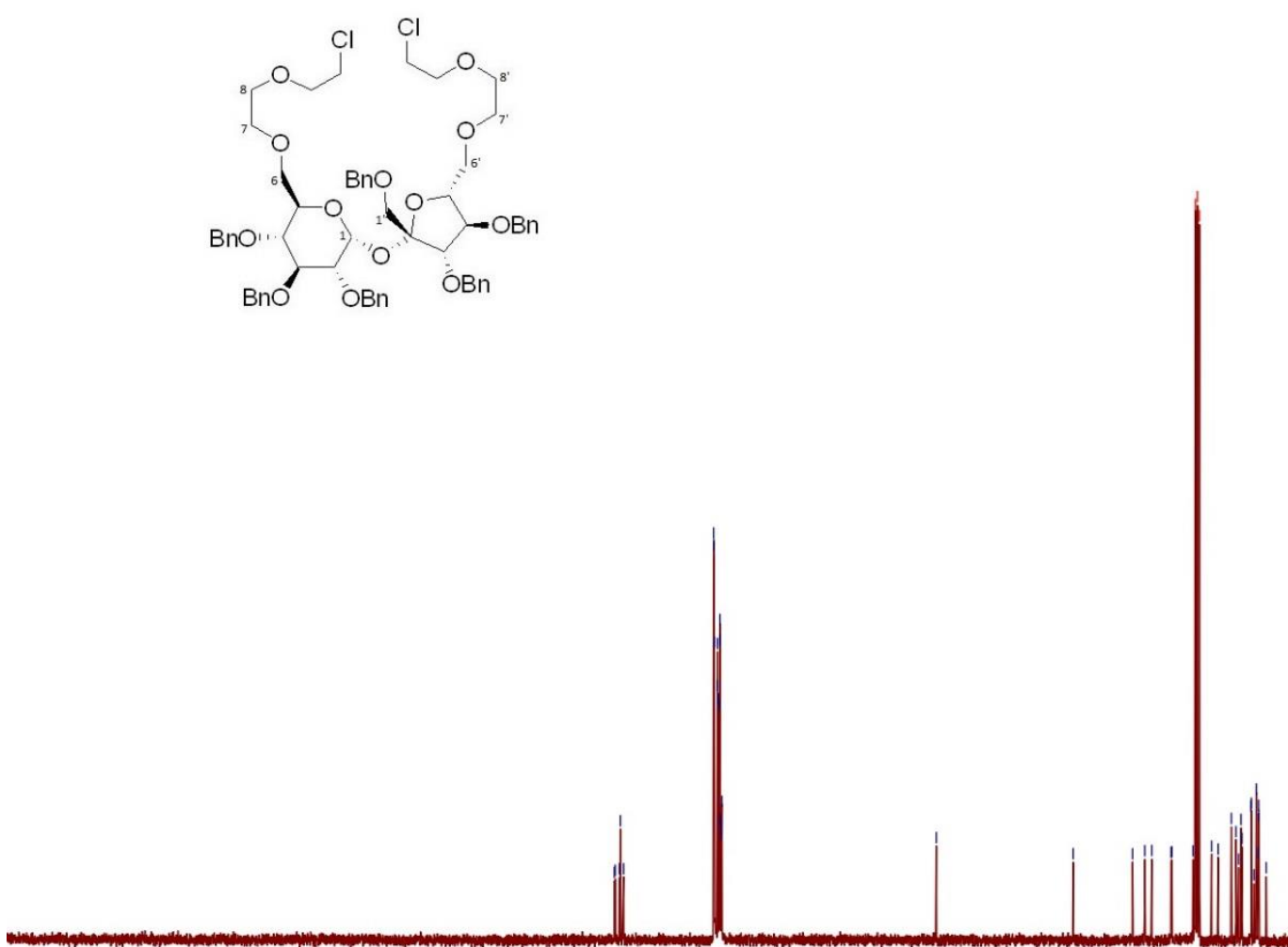

200

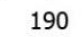

180

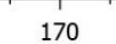

160

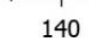

130

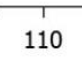

100
f1 $(\mathrm{ppm})$
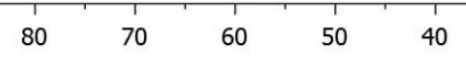

30

20

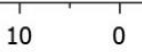

Figure S36. ${ }^{13} \mathrm{C}$ NMR $\left(151 \mathrm{MHz}, \mathrm{CDCl}_{3}\right)$ spectrum of compound 6. 


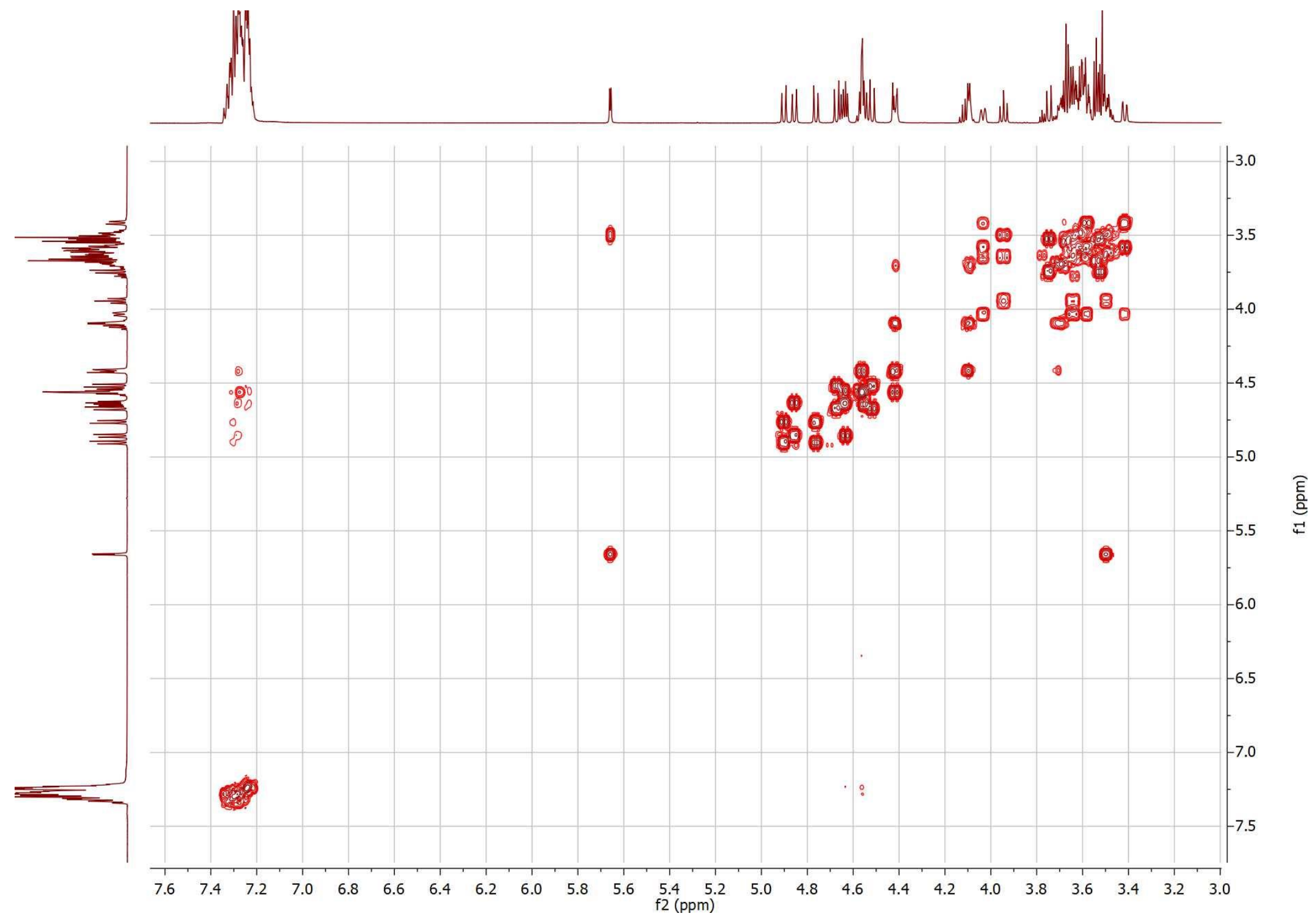

Figure S37. gCOSY spectrum of compound 6. 


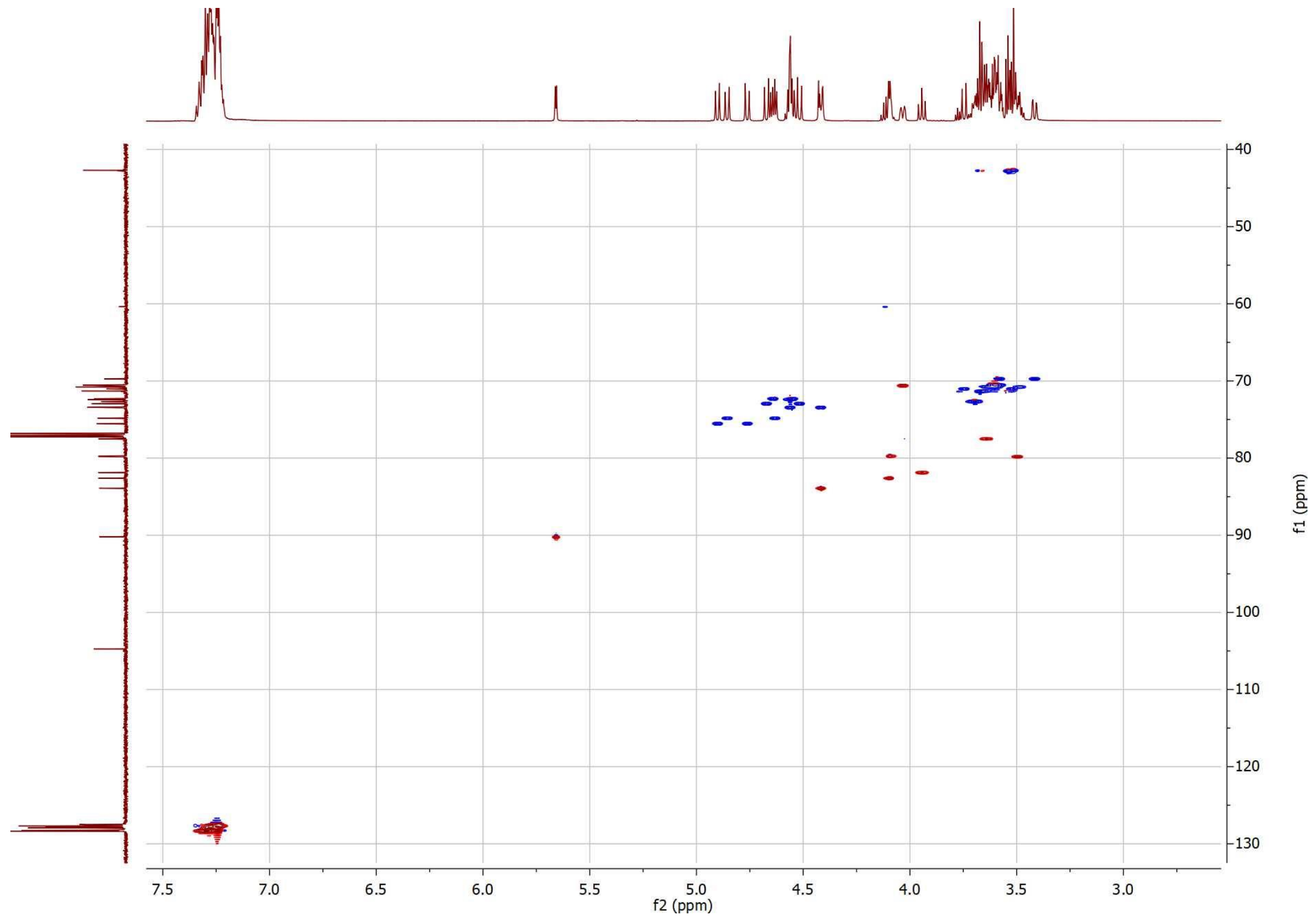

Figure S38. gHSQCAD spectrum of compound 6. 


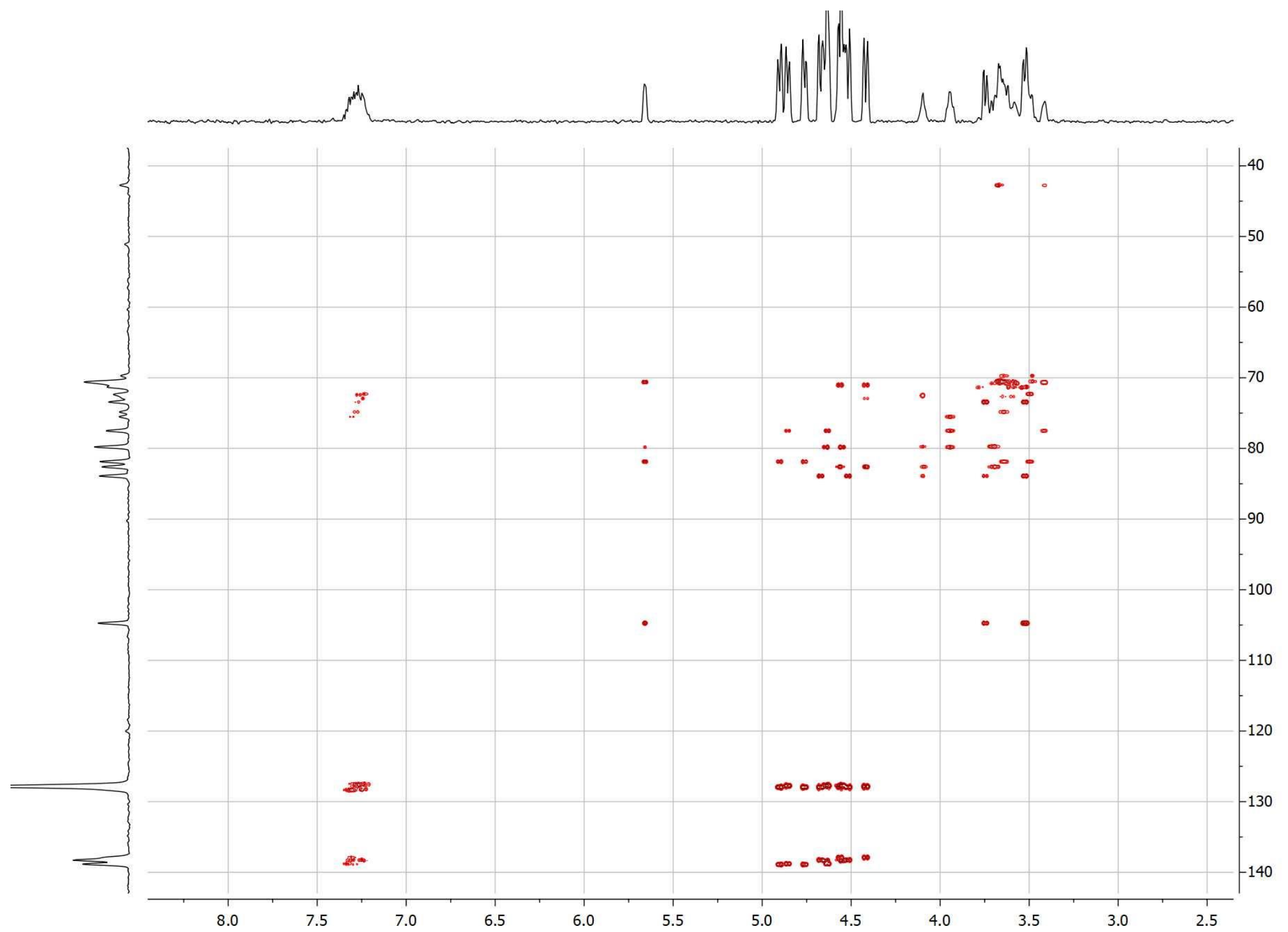

Figure S39. gHMBCAD spectrum of compound 6. 


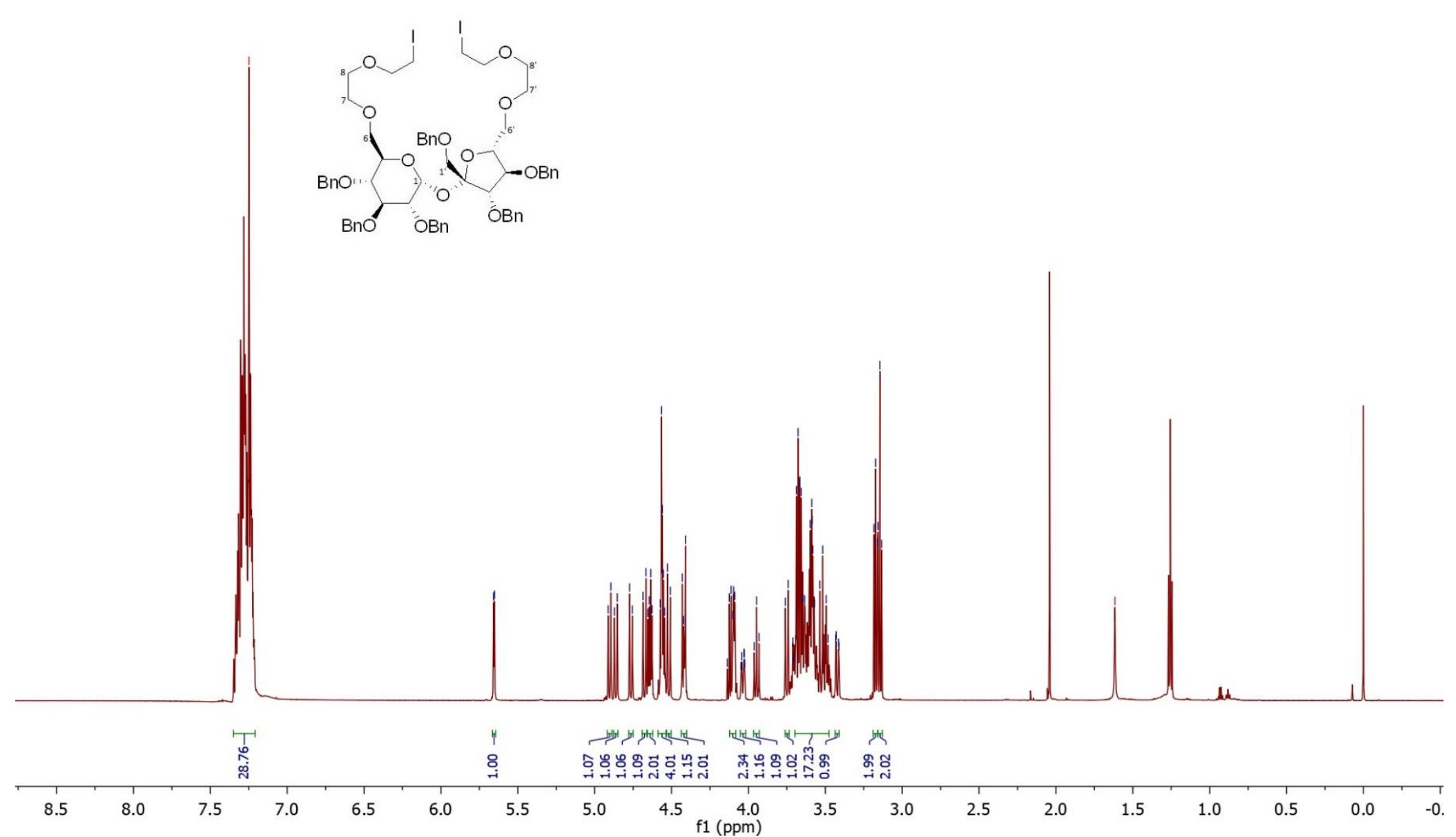

Figure S40. ${ }^{1} \mathrm{H}$ NMR $\left(600 \mathrm{MHz}, \mathrm{CDCl}_{3}\right)$ spectrum of compound 7. 


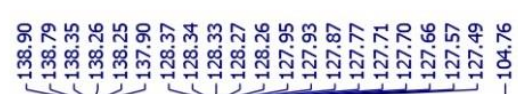

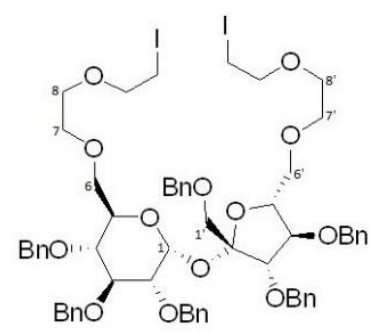




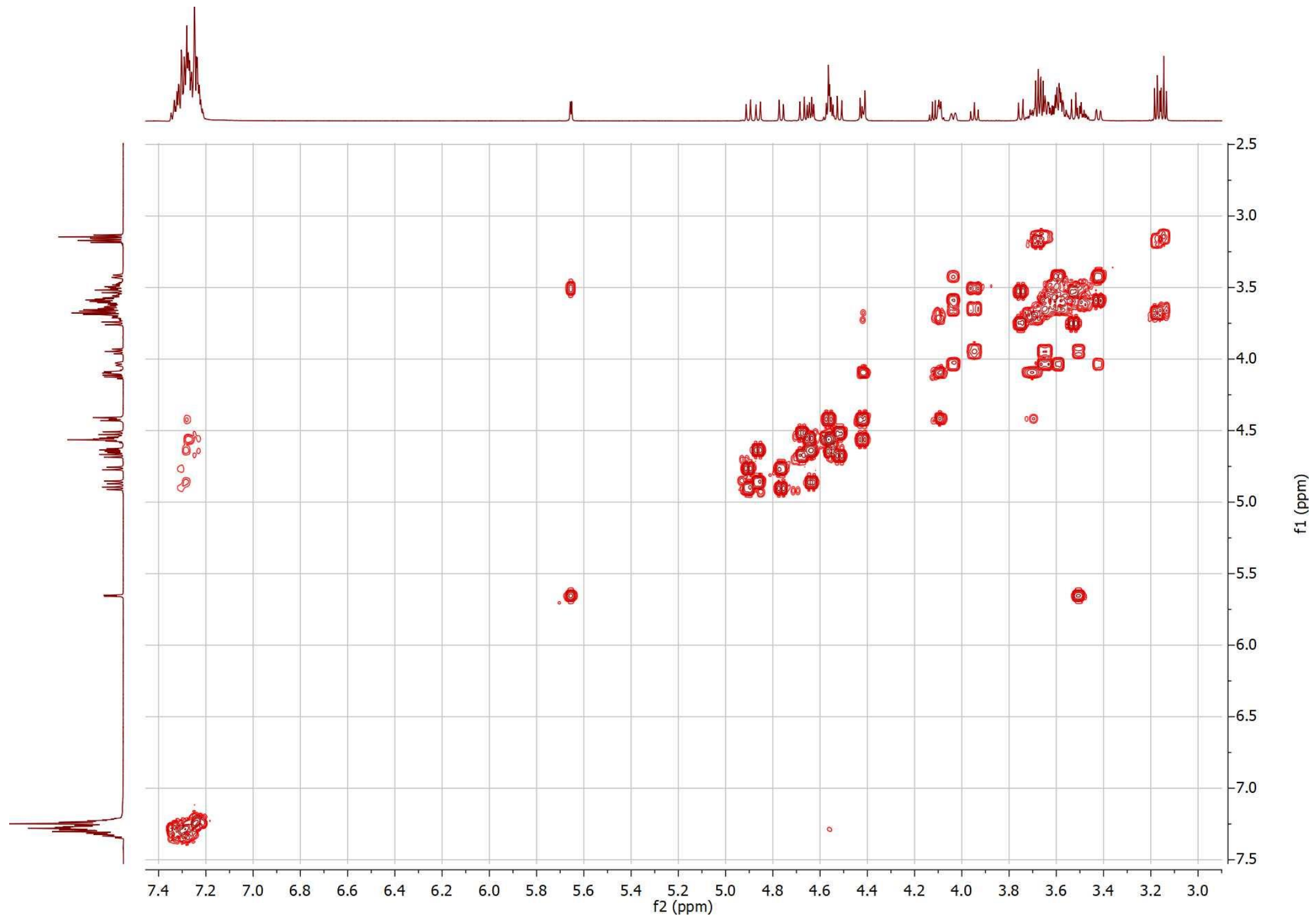

Figure S42. gCOSY spectrum of compound 7. 


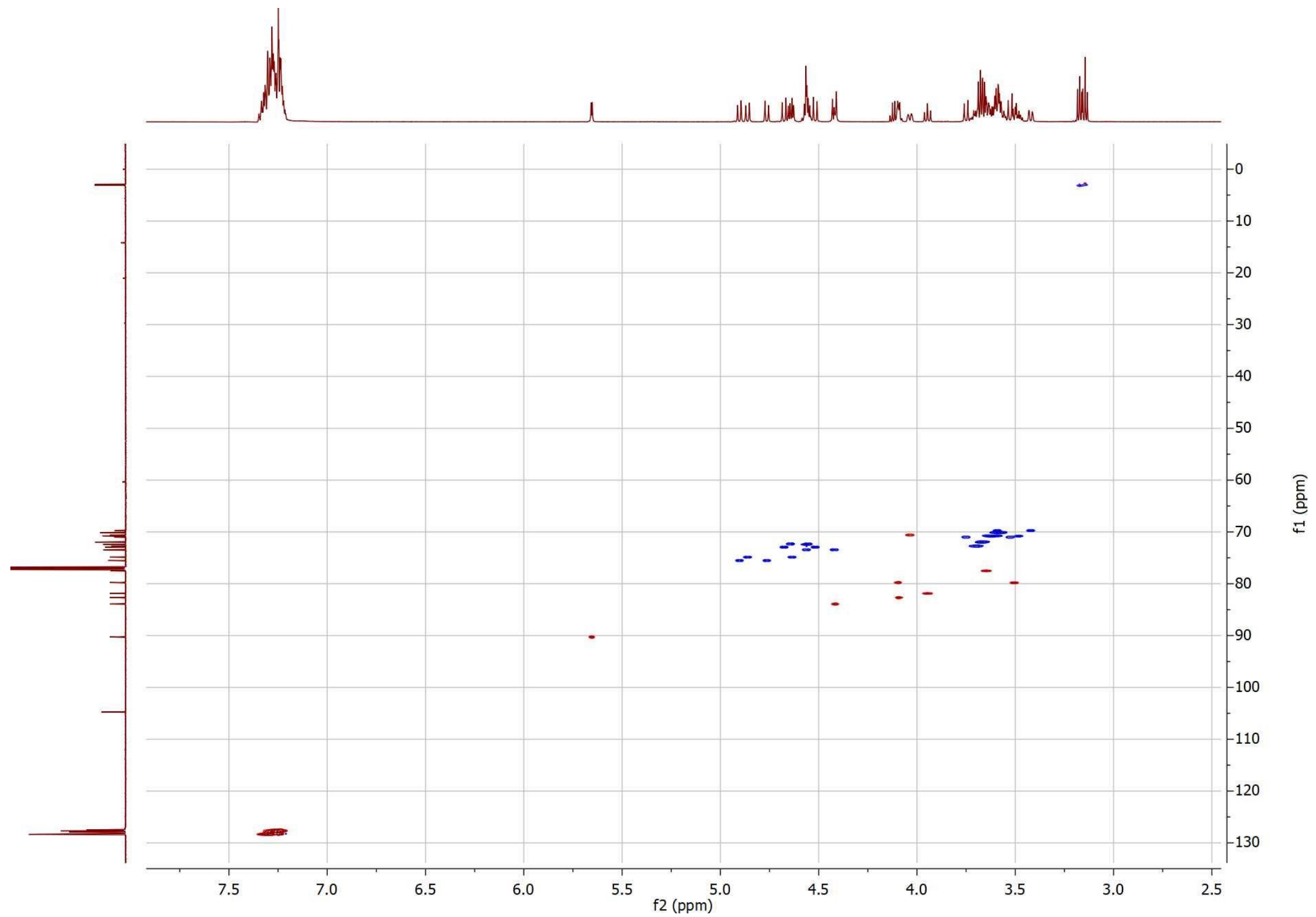

Figure S43. gHSQCAD spectrum of compound 7. 


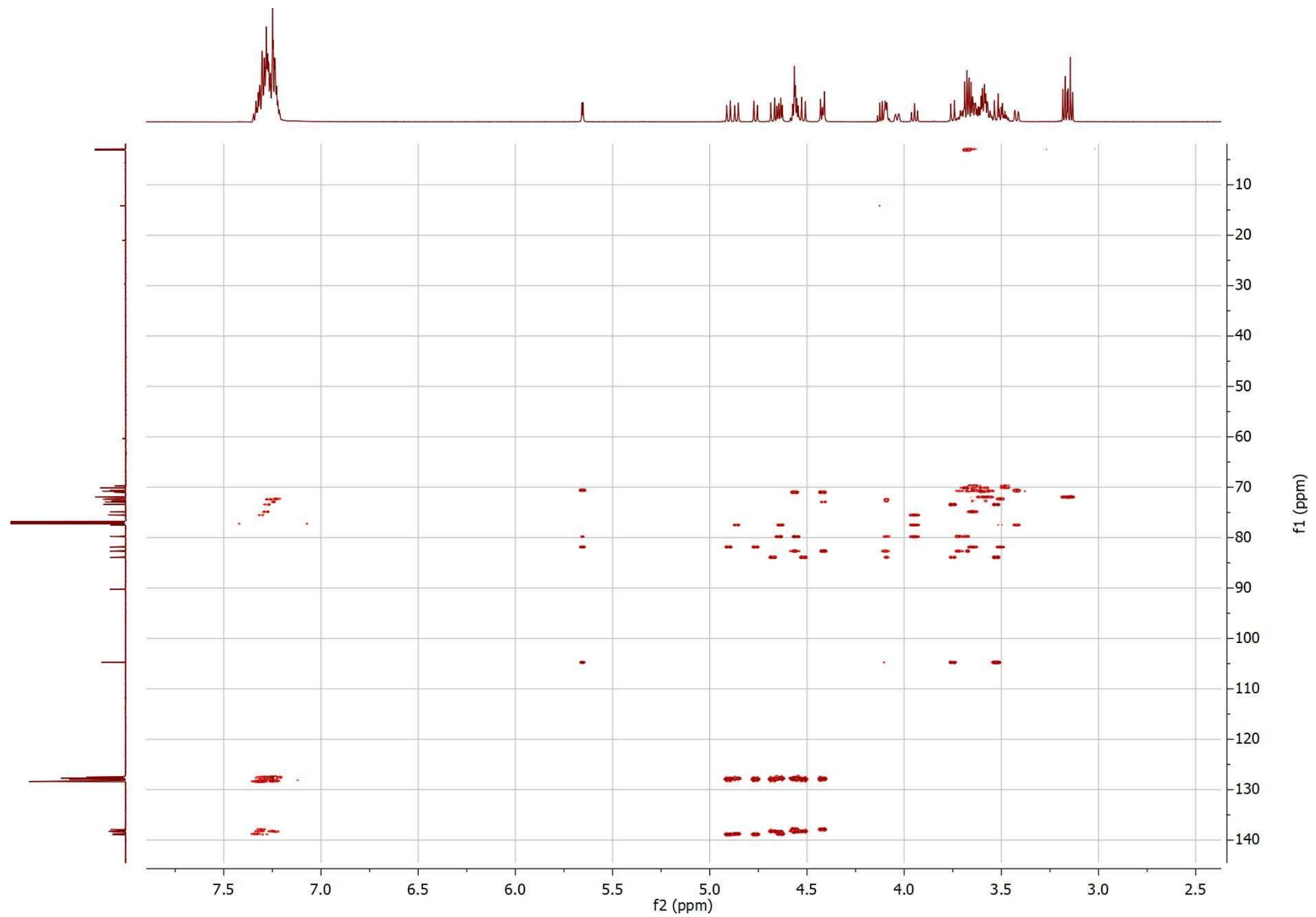

Figure S44. gHMBCAD spectrum of compound 7. 


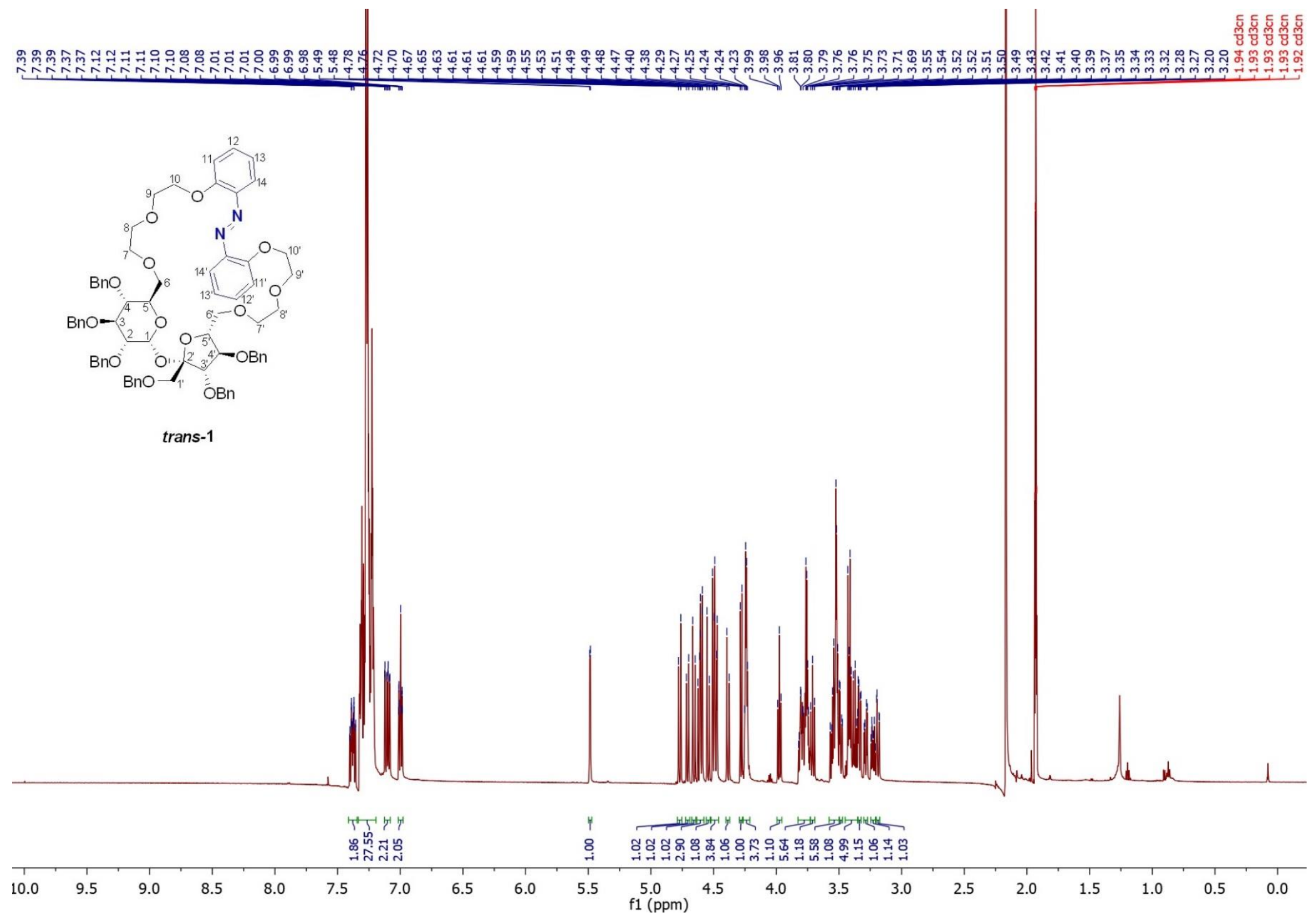

Figure S45. ${ }^{1} \mathrm{H}$ NMR $\left(600 \mathrm{MHz}, \mathrm{CD}_{3} \mathrm{CN}\right)$ spectrum of pure trans-1. 


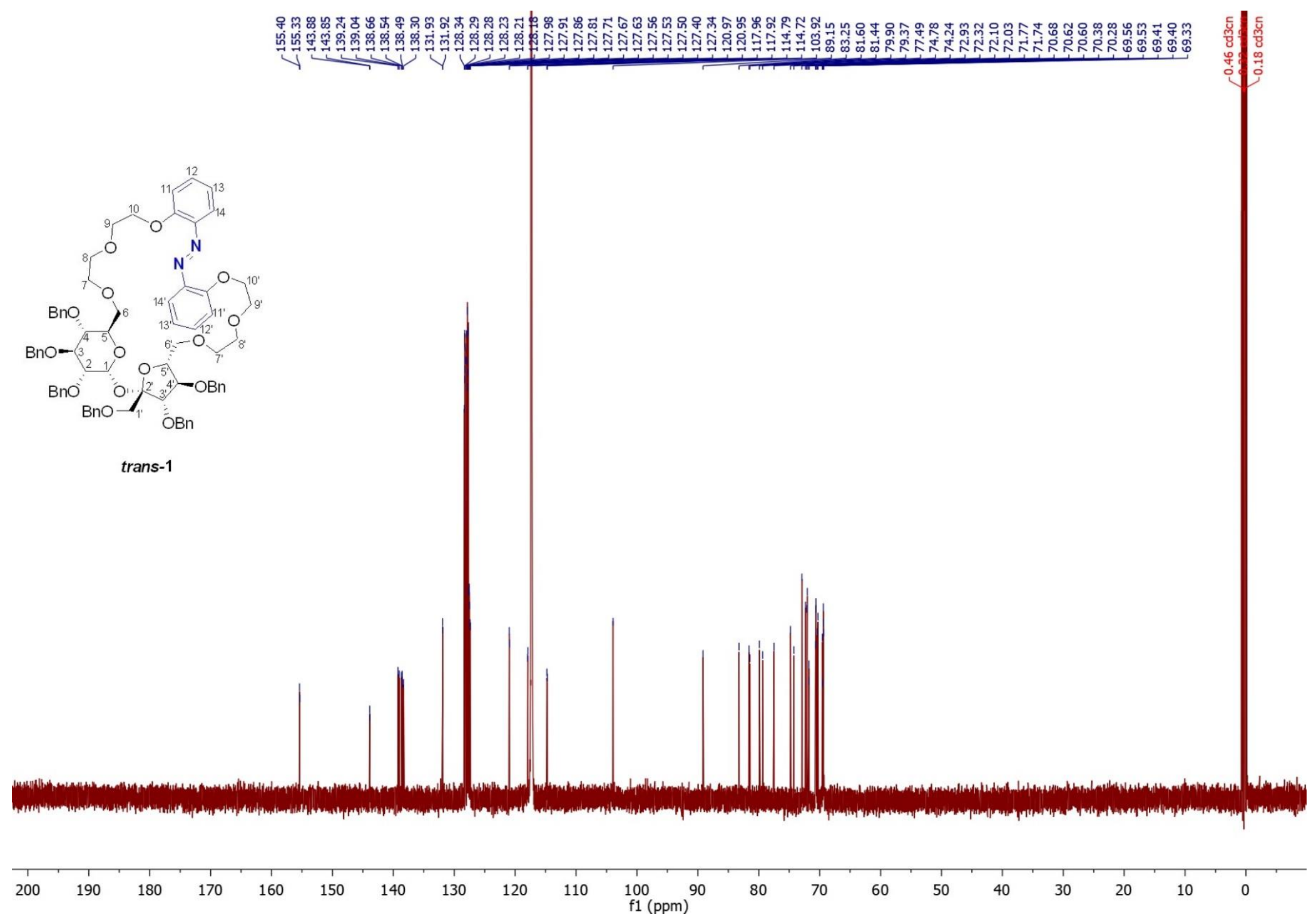

Figure S46. ${ }^{13} \mathrm{C}$ NMR $\left(151 \mathrm{MHz}, \mathrm{CD}_{3} \mathrm{CN}\right)$ spectrum of pure trans-1. 


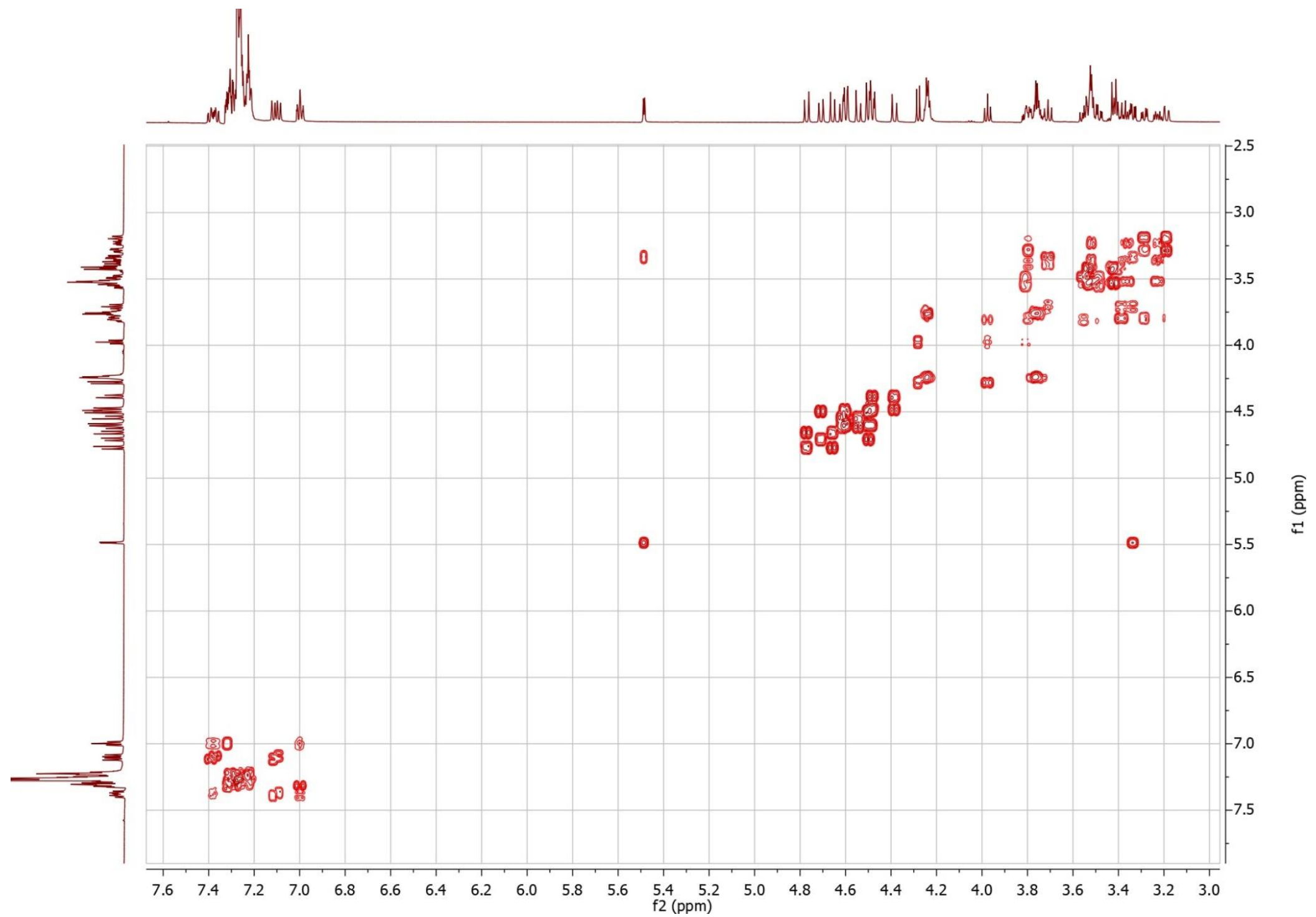

Figure S47. gCOSY spectrum of pure trans-1. 


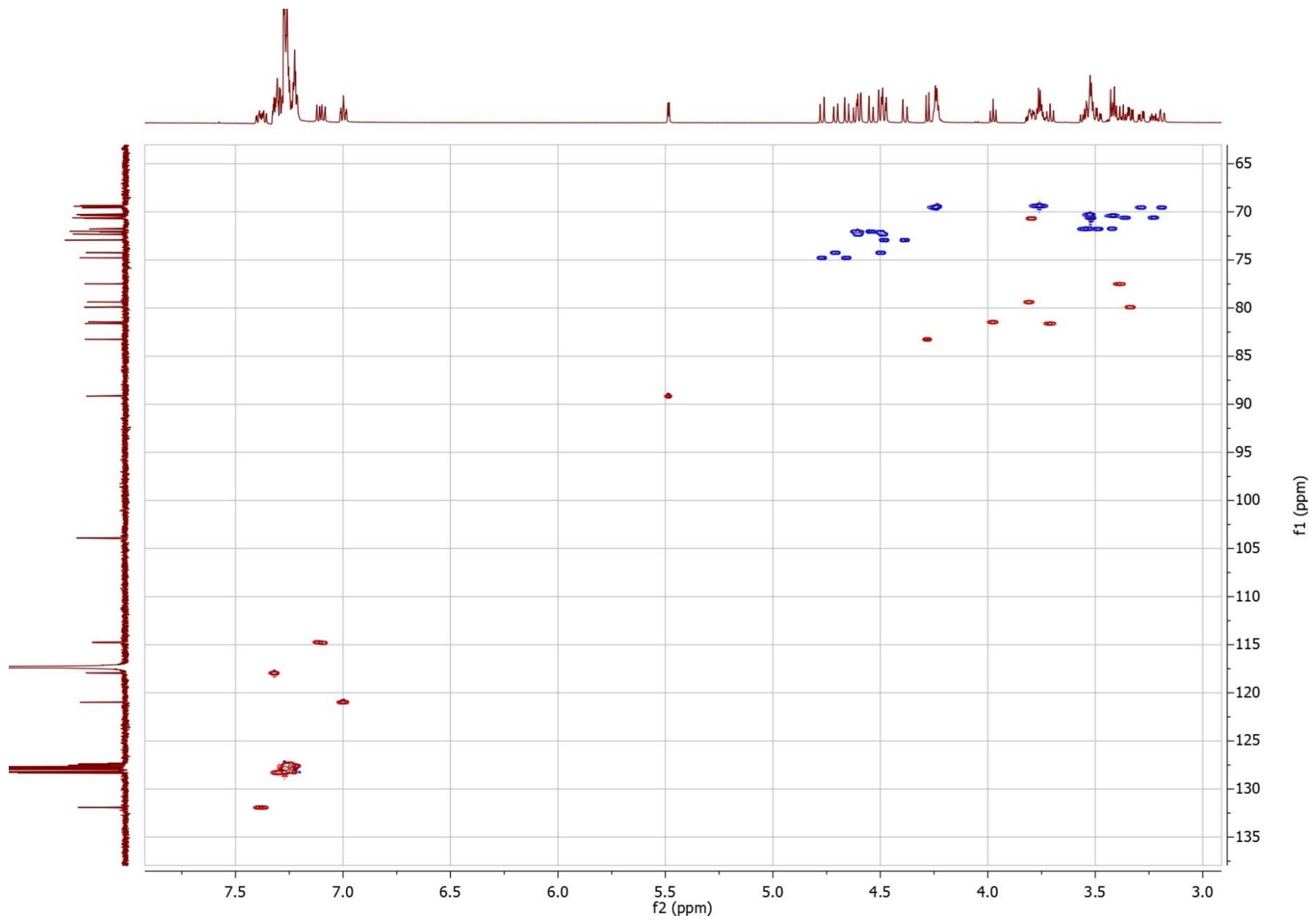

Figure S48. gHSQCAD spectrum of pure trans-1. 


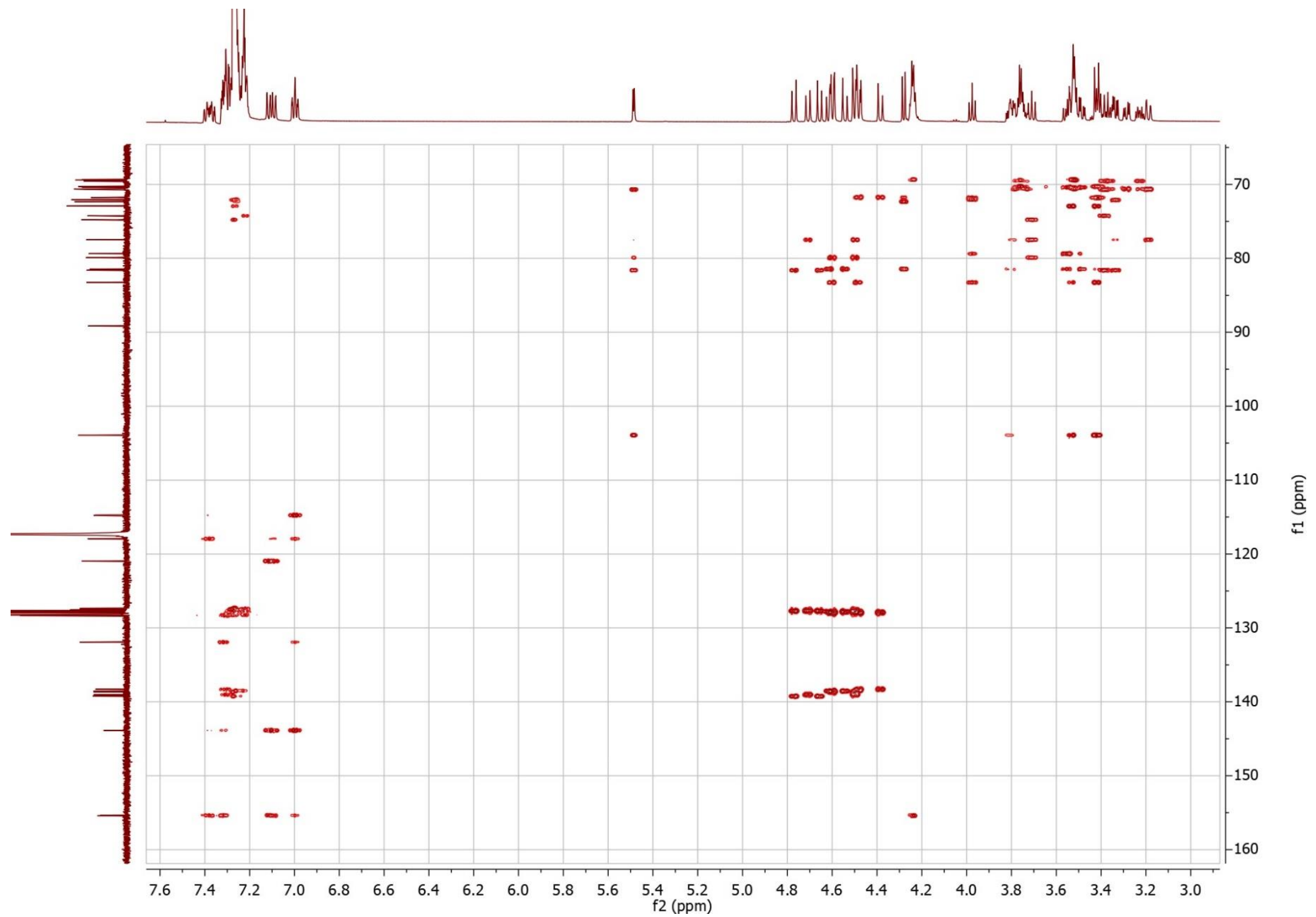

Figure S49. gHMBCAD spectrum of pure trans-1. 


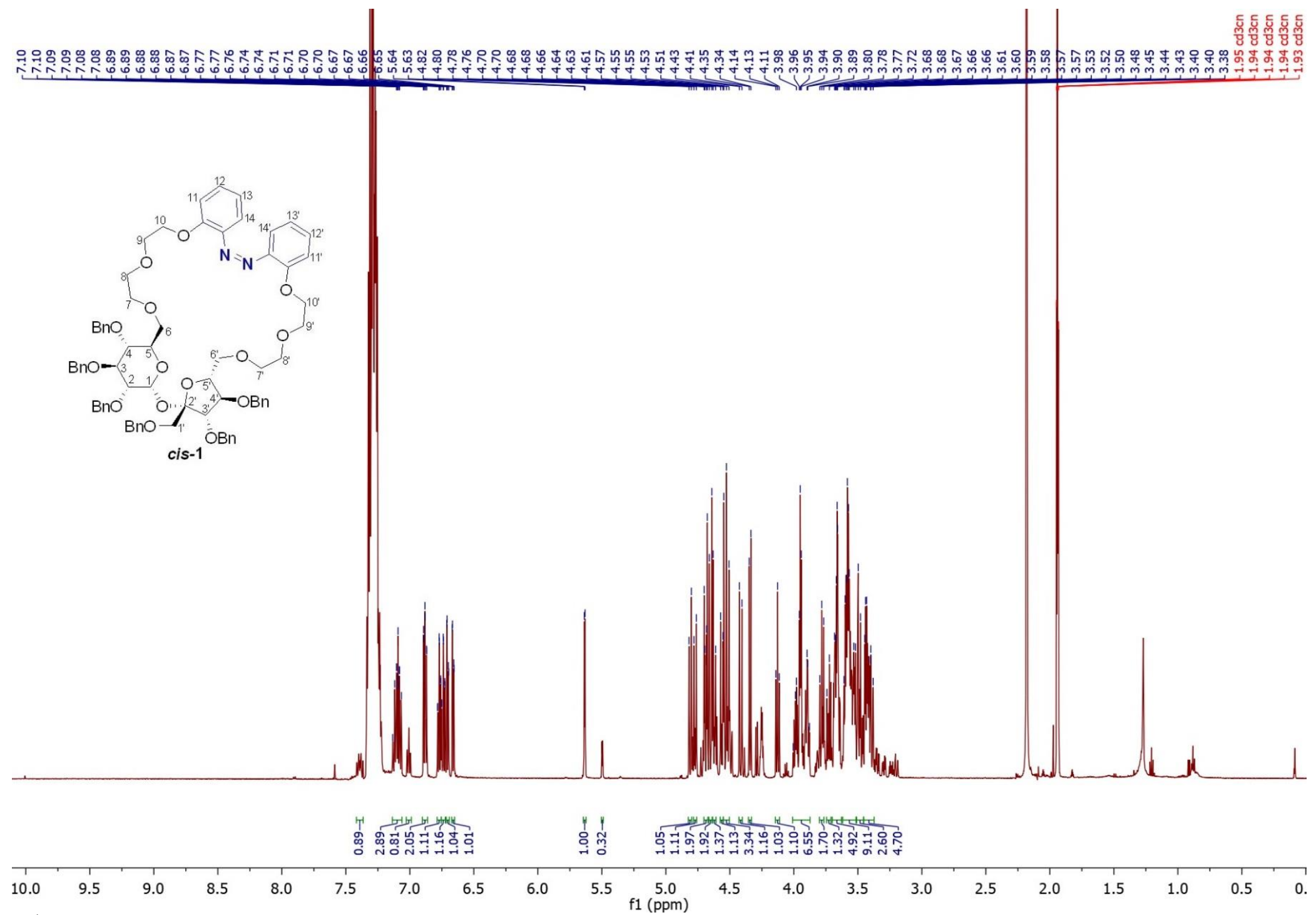

Figure S50. ${ }^{1} \mathrm{H}$ NMR $\left(600 \mathrm{MHz}, \mathrm{CD}_{3} \mathrm{CN}\right)$ spectrum of cis-1 (as cis-enriched mixture containing ca. $24.2 \%$ of trans-isomer). 


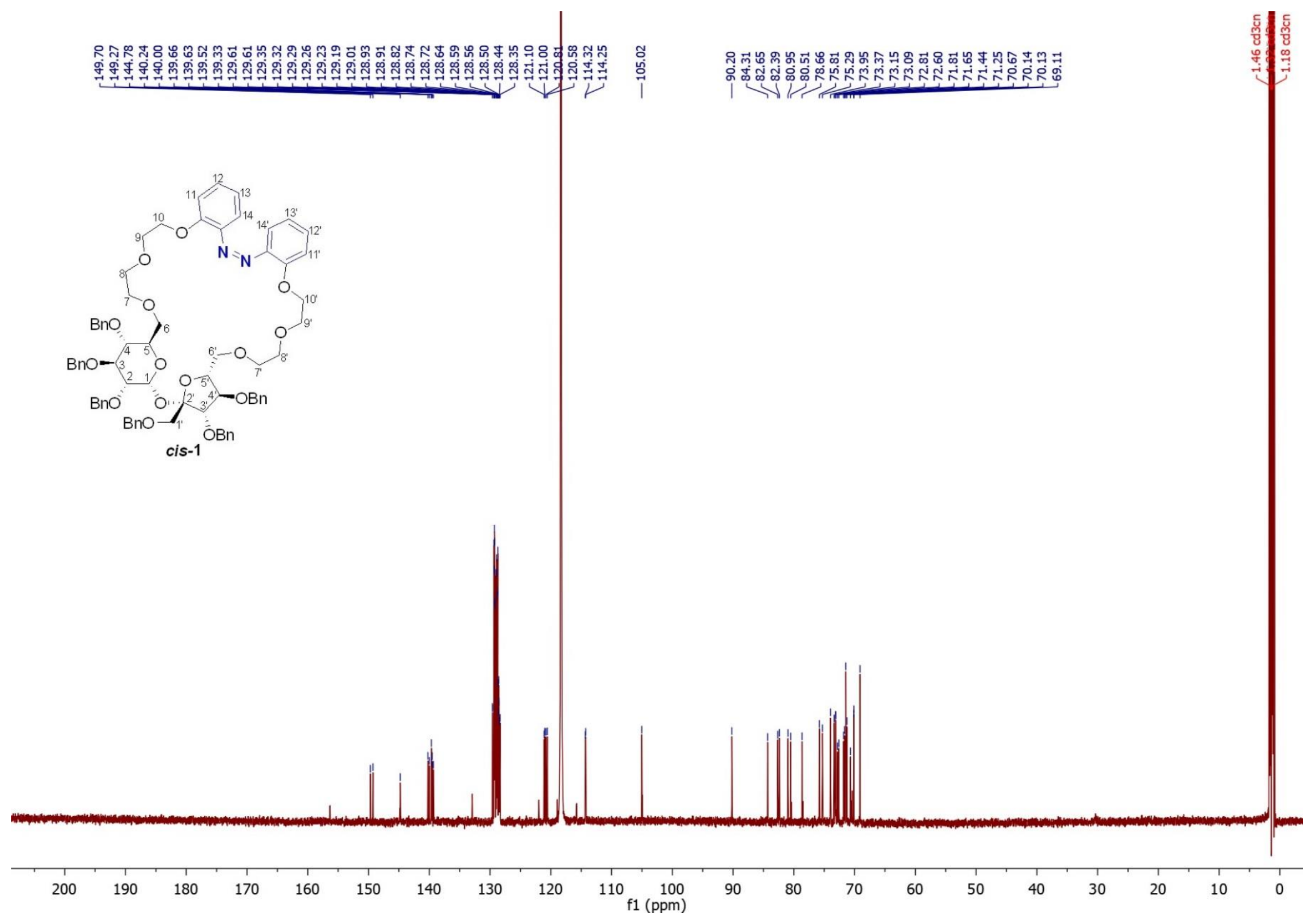

Figure S51. ${ }^{13} \mathrm{C}$ NMR $\left(151 \mathrm{MHz}, \mathrm{CD}_{3} \mathrm{CN}\right)$ spectrum of compound cis-1 (as cis-enriched mixture containing ca. 24.2\% of trans-isomer). 


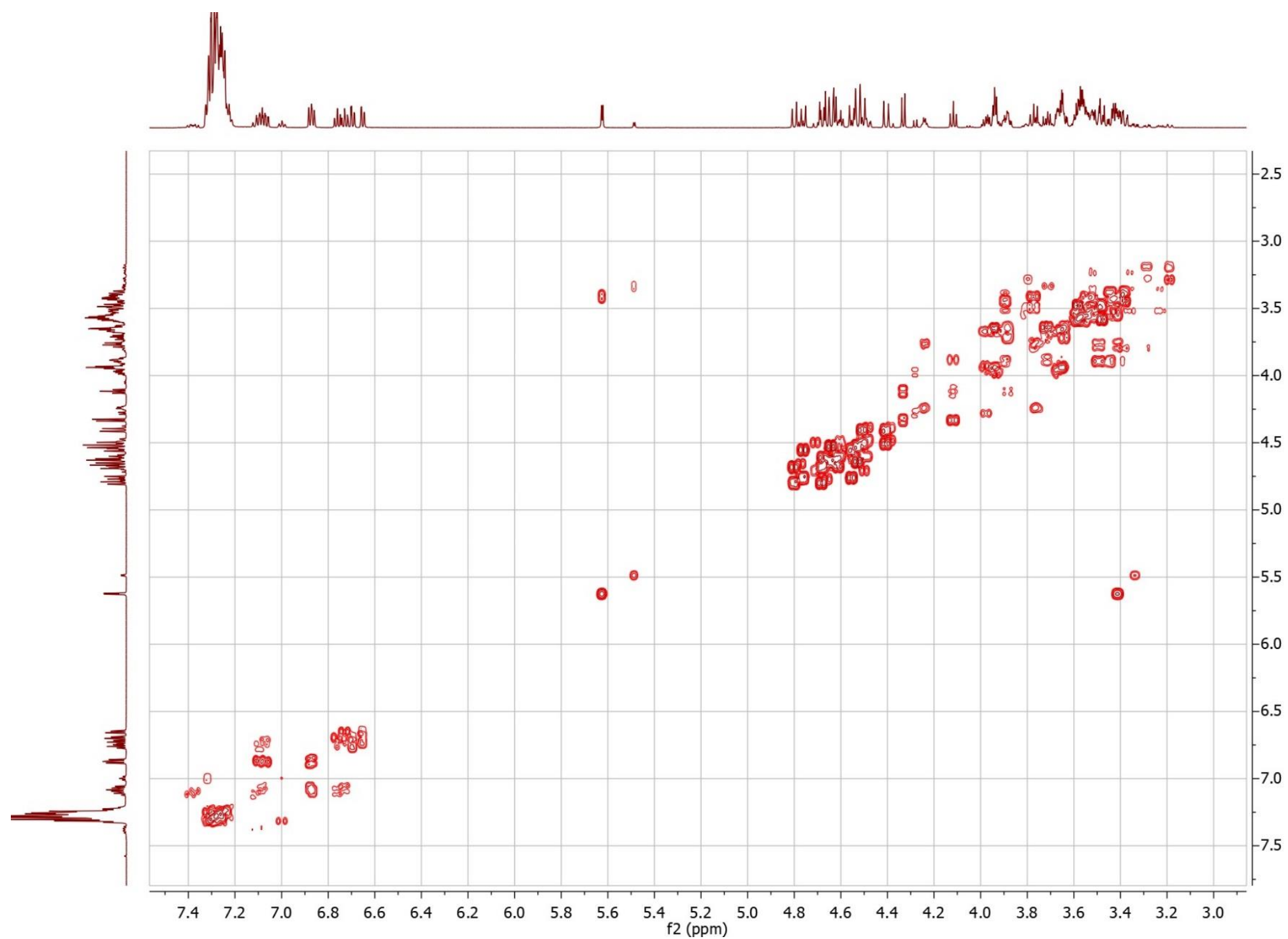

Figure S52. gCOSY spectrum of compound cis-1 (as cis-enriched mixture containing ca. $24.2 \%$ of trans-isomer). 


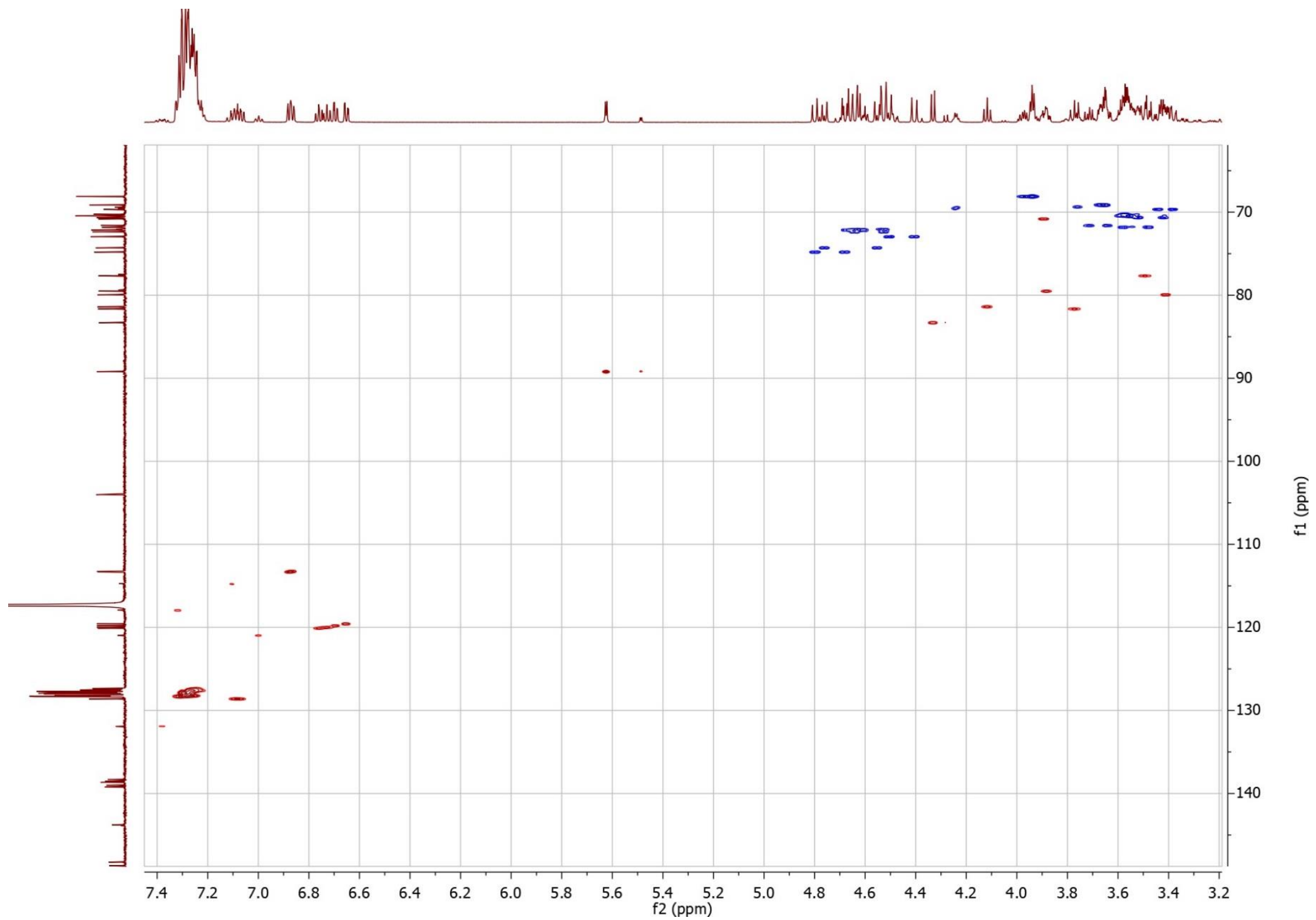

Figure S53. gHSQCAD spectrum of compound cis-1 (as cis-enriched mixture containing ca. $24.2 \%$ of trans-isomer). 


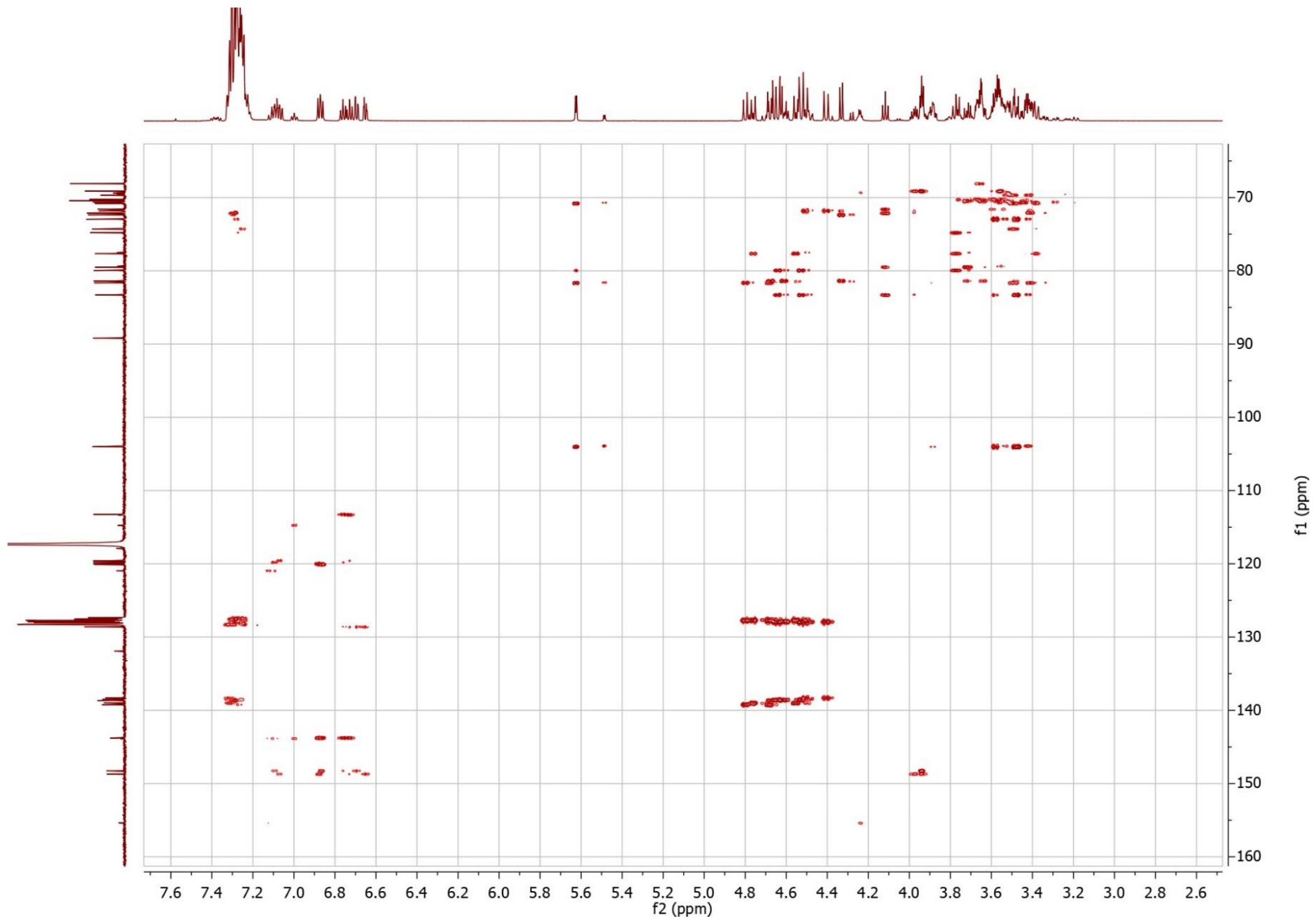

Figure S54. gHMBCAD spectrum of compound cis-1 (as cis-enriched mixture containing ca. $24.2 \%$ of trans-isomer). 


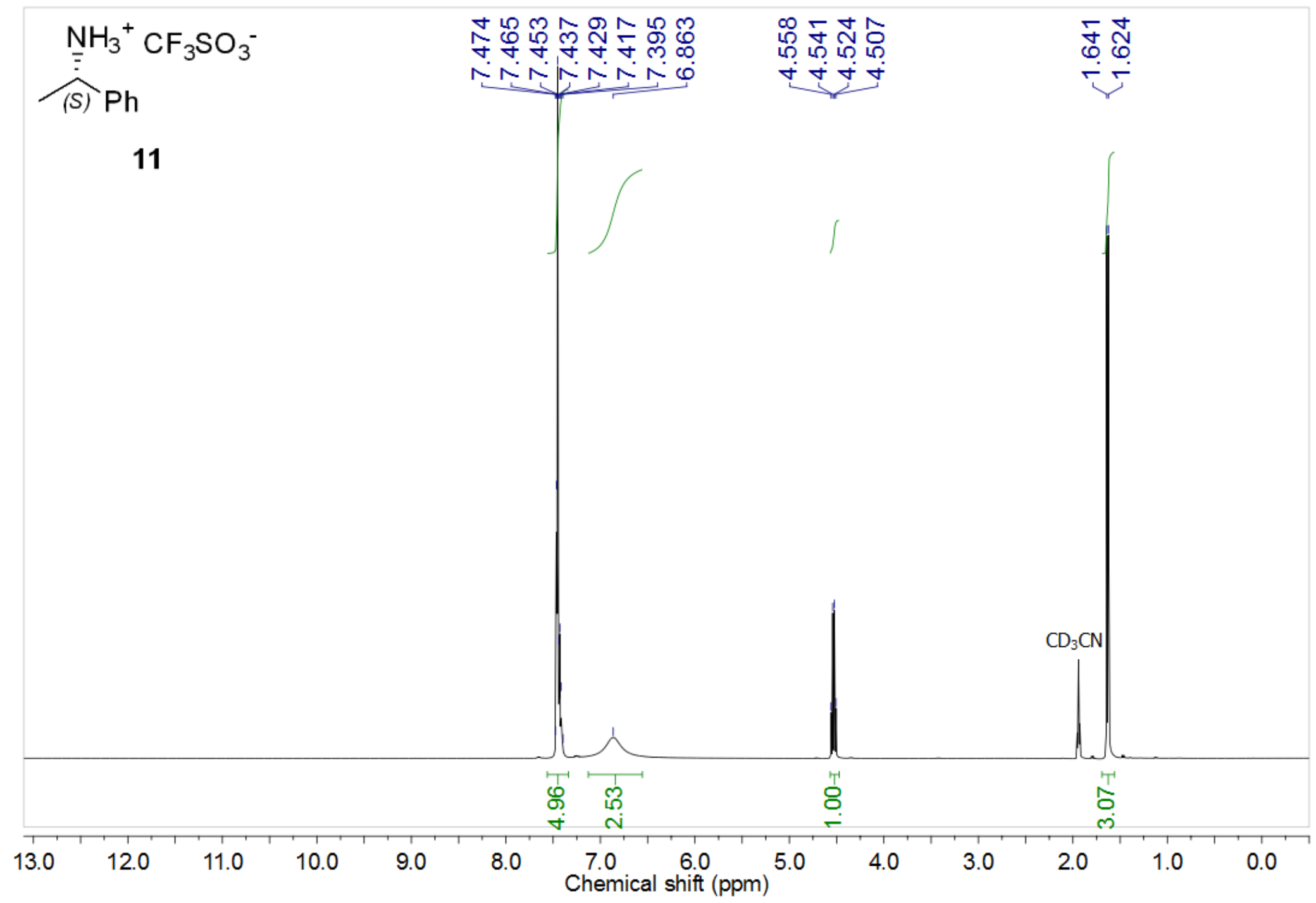

Figure S55. ${ }^{1} \mathrm{H}$ NMR (400 MHz, $\left.\mathrm{CD}_{3} \mathrm{CN}\right)$ spectrum of $(S)$-2-phenylethylammonium triflate (11). 


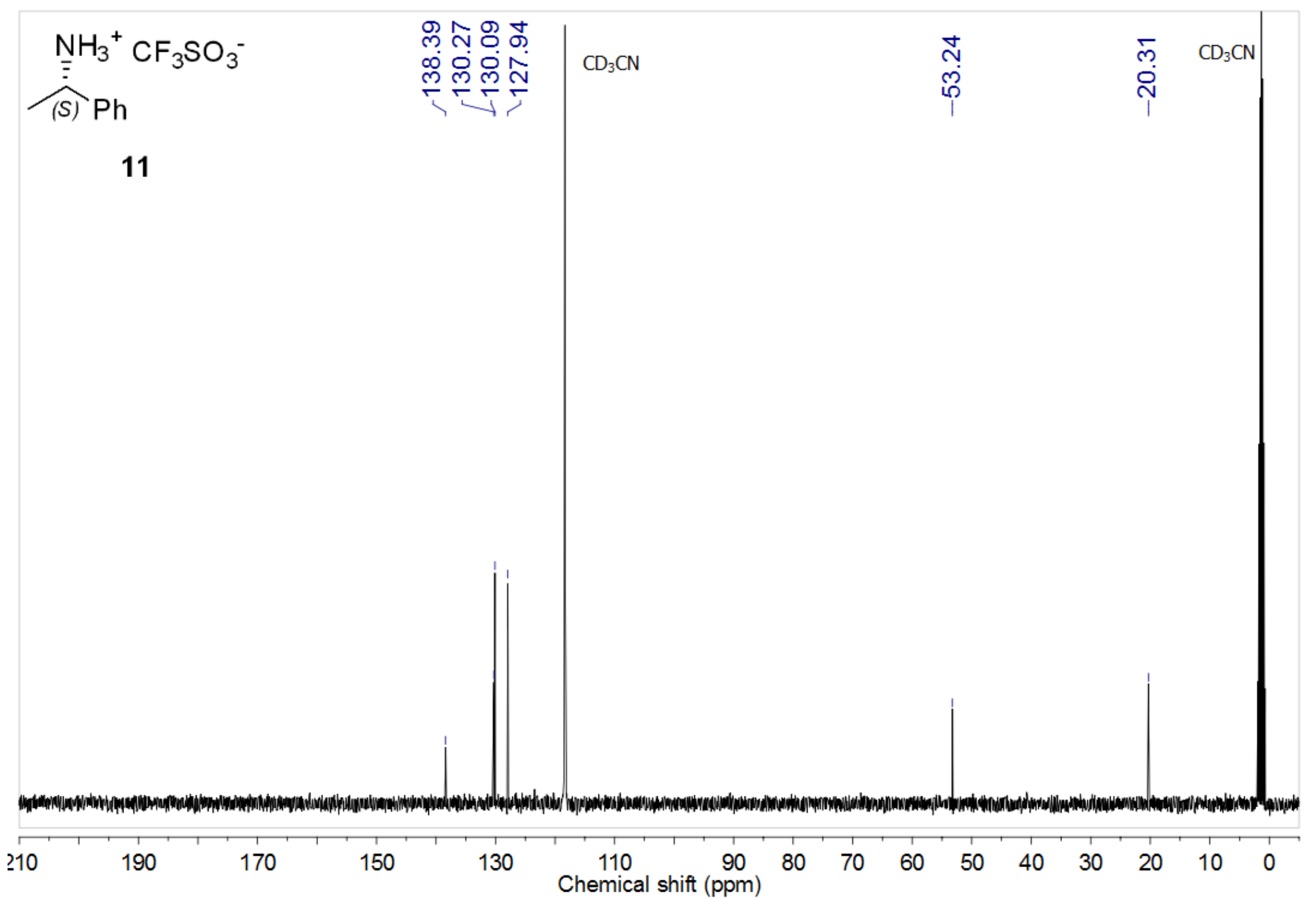

Figure S56. ${ }^{13} \mathrm{C}$ NMR $\left(100 \mathrm{MHz}, \mathrm{CD}_{3} \mathrm{CN}\right)$ spectrum of $(S)$-2-phenylethylammonium triflate (11). 


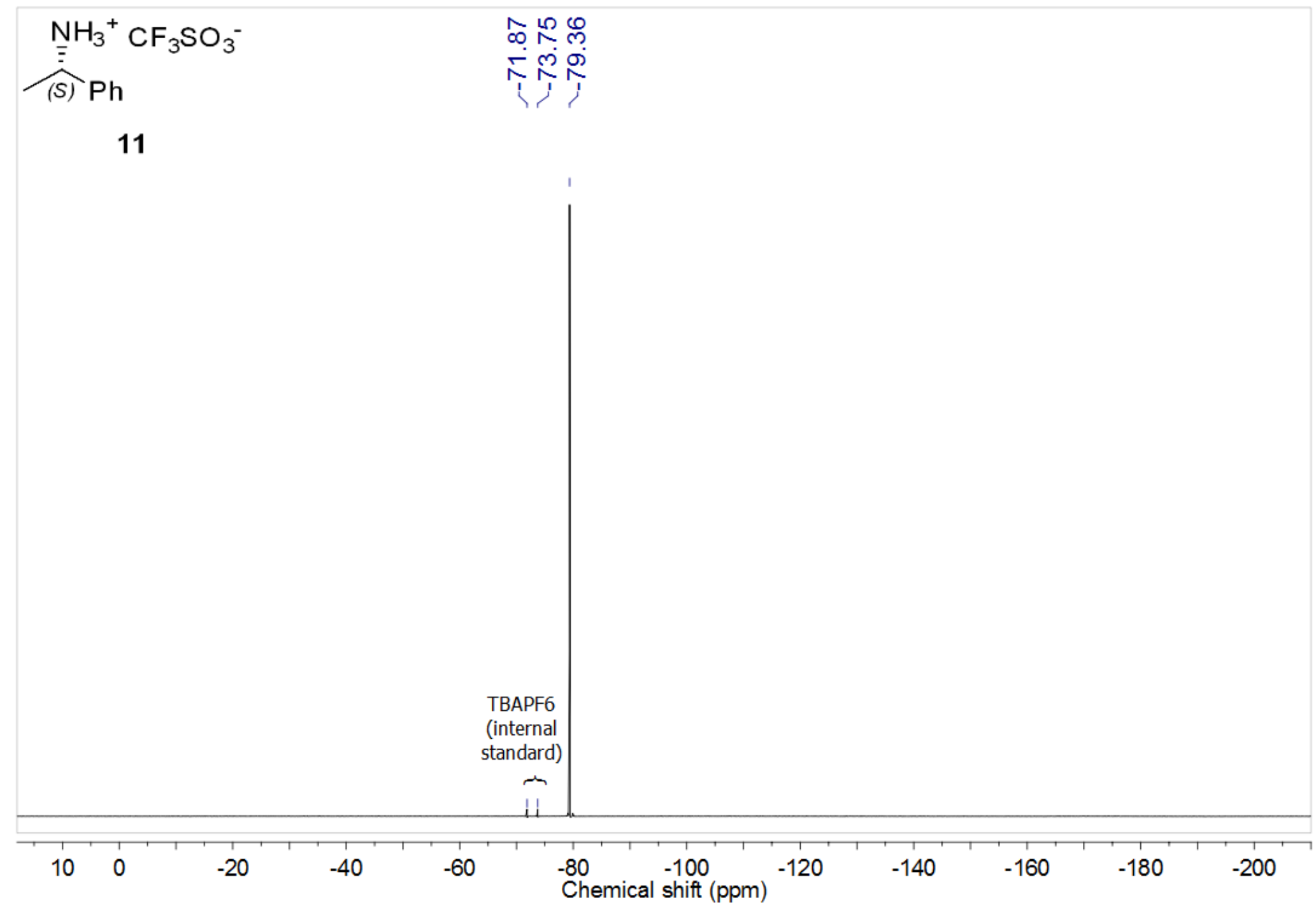

Figure S57. ${ }^{19} \mathrm{~F}$ NMR (376 MHz, $\left.\mathrm{CD}_{3} \mathrm{CN}\right)$ spectrum of $(S)$-2-phenylethylammonium triflate (11). 


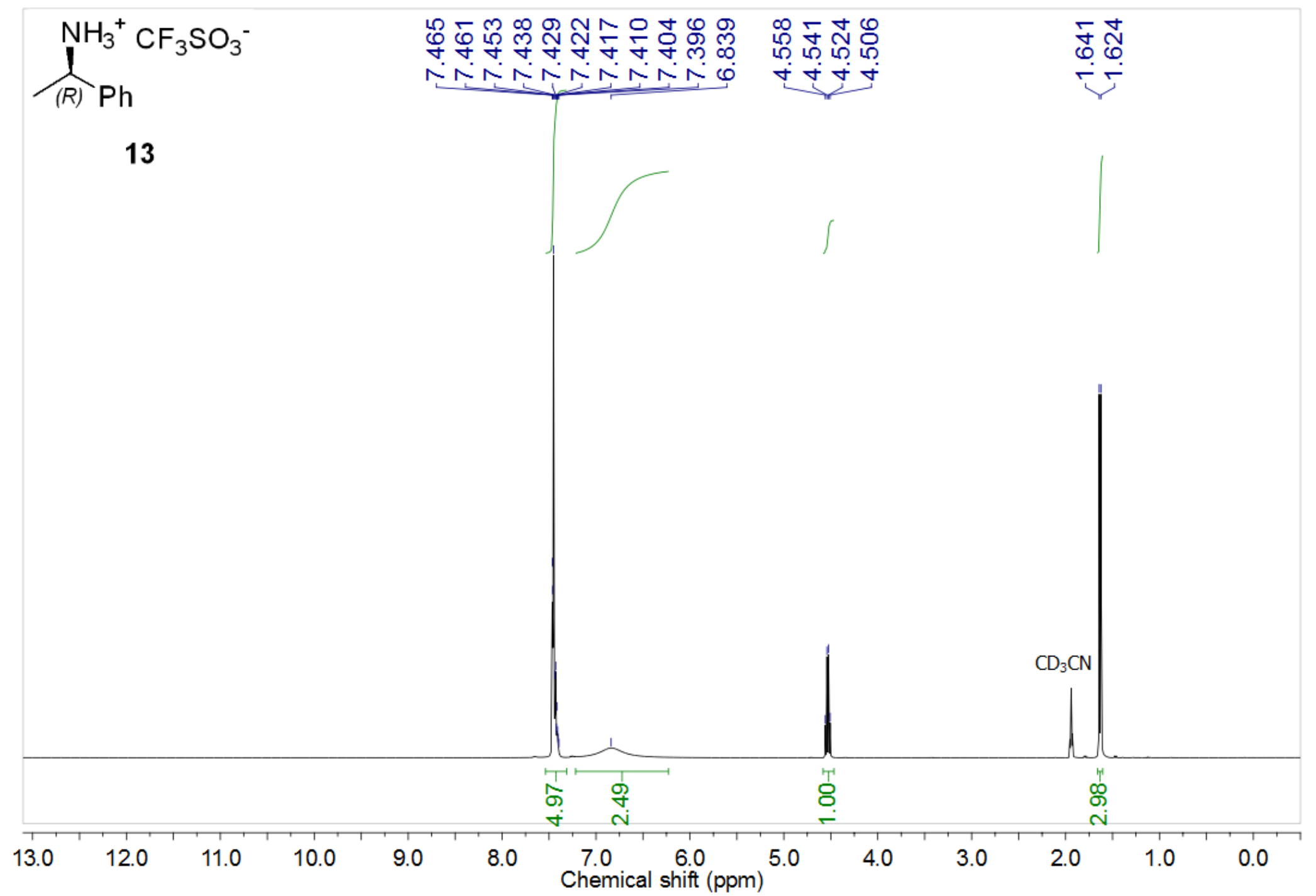

Figure S58. ${ }^{1} \mathrm{H}$ NMR $\left(400 \mathrm{MHz}, \mathrm{CD}_{3} \mathrm{CN}\right)$ spectrum of $(R)$-2-phenylethylammonium triflate $(\mathbf{1 3})$. 


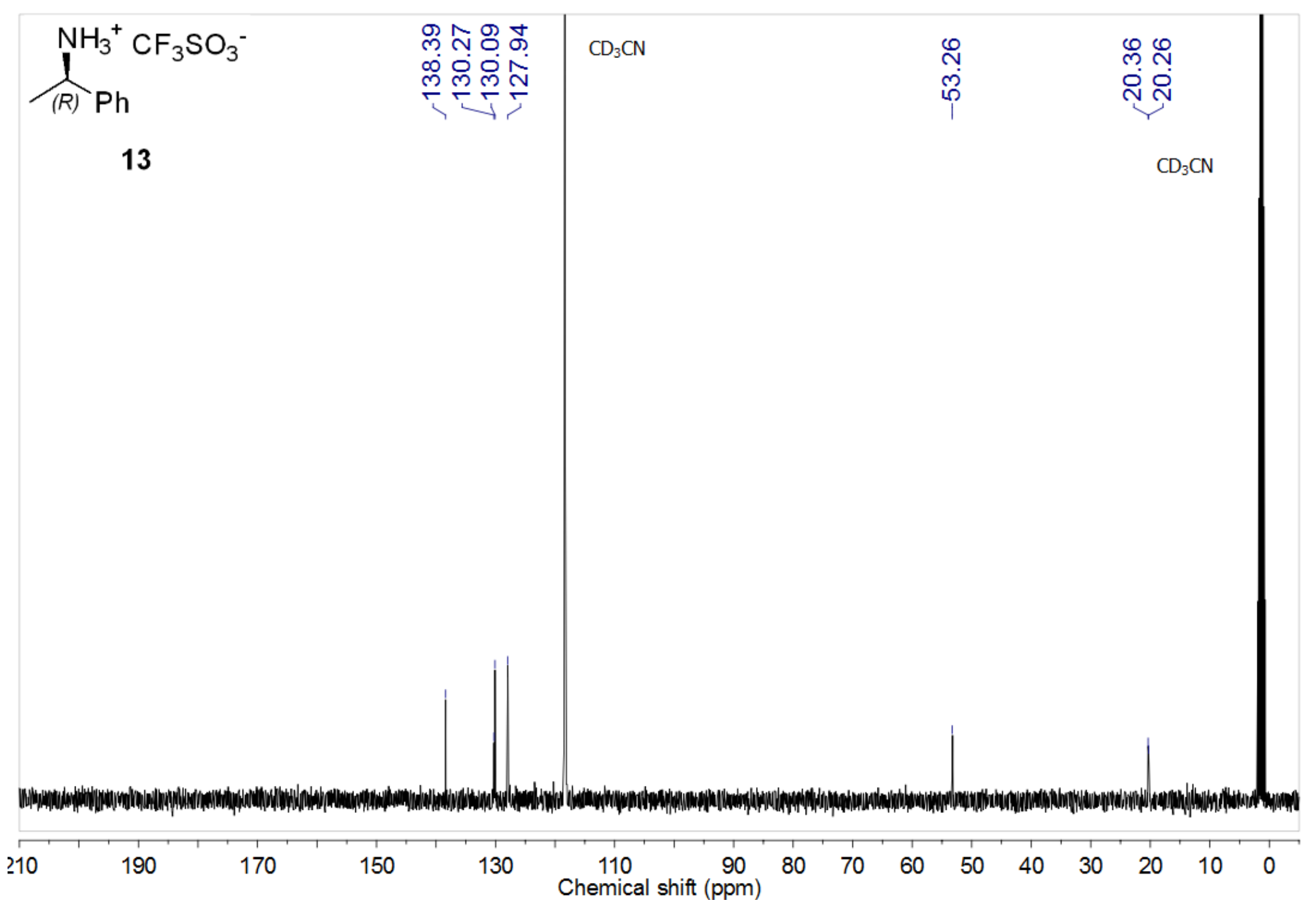

Figure S59. ${ }^{13} \mathrm{C}$ NMR $\left(100 \mathrm{MHz}, \mathrm{CD}_{3} \mathrm{CN}\right)$ spectrum of $(R)$-2-phenylethylammonium triflate (11). 


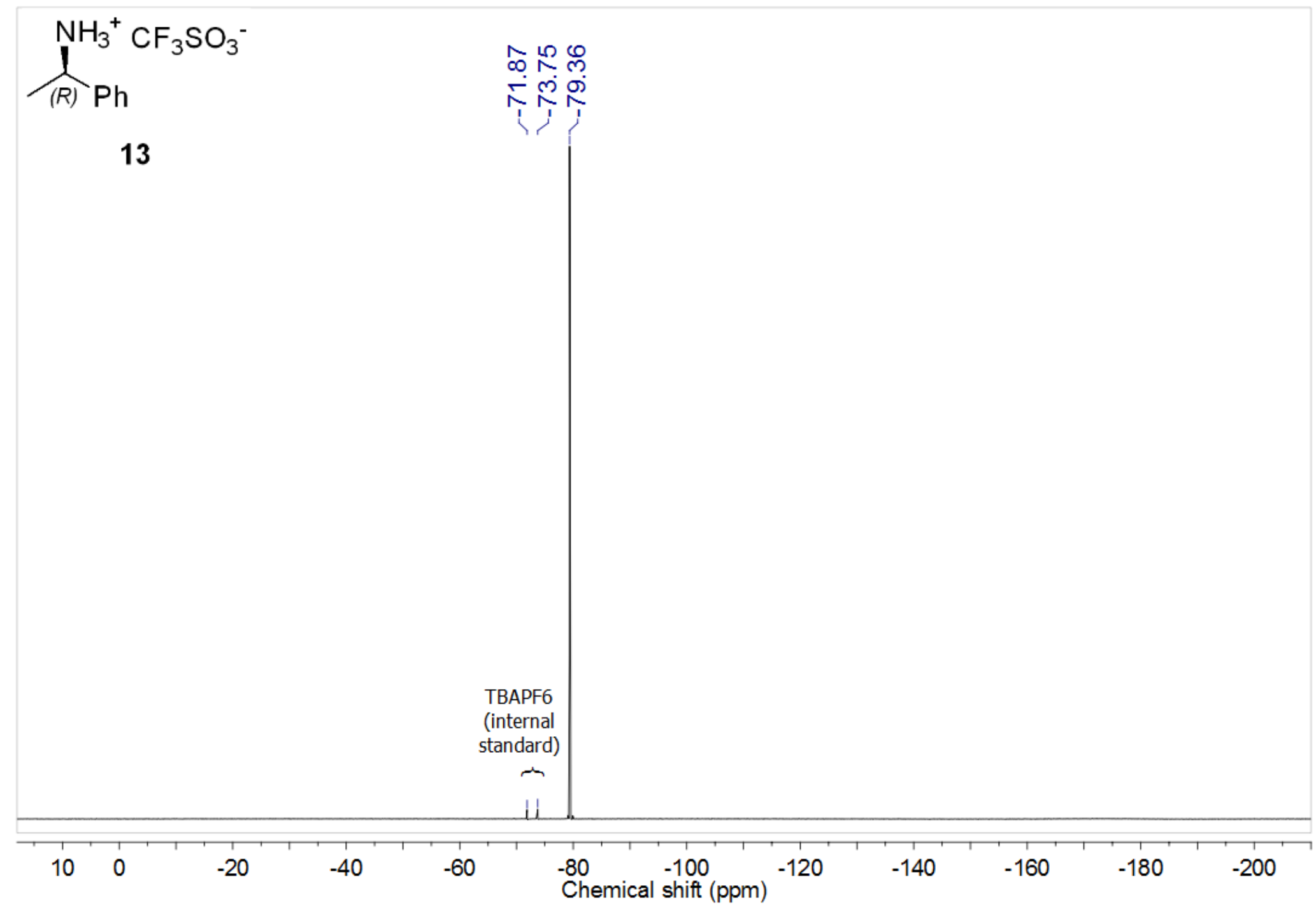

Figure S60. ${ }^{19} \mathrm{~F}$ NMR $\left(376 \mathrm{MHz}, \mathrm{CD}_{3} \mathrm{CN}\right)$ spectrum of $(R)$-2-phenylethylammonium triflate $(\mathbf{1 3})$. 


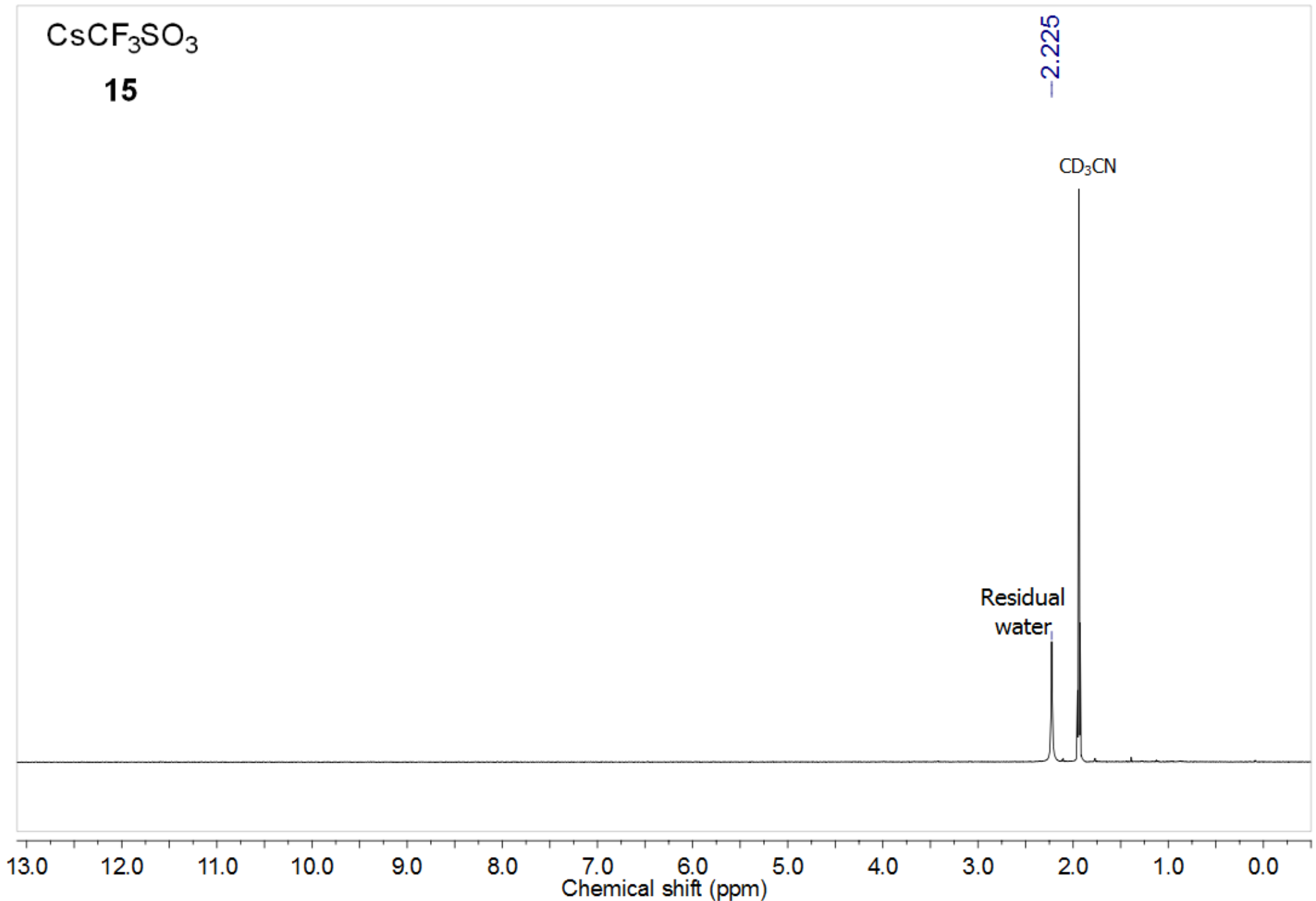

Figure S61. ${ }^{1} \mathrm{H}$ NMR $\left(400 \mathrm{MHz}, \mathrm{CD}_{3} \mathrm{CN}\right)$ spectrum of cesium triflate (15). 


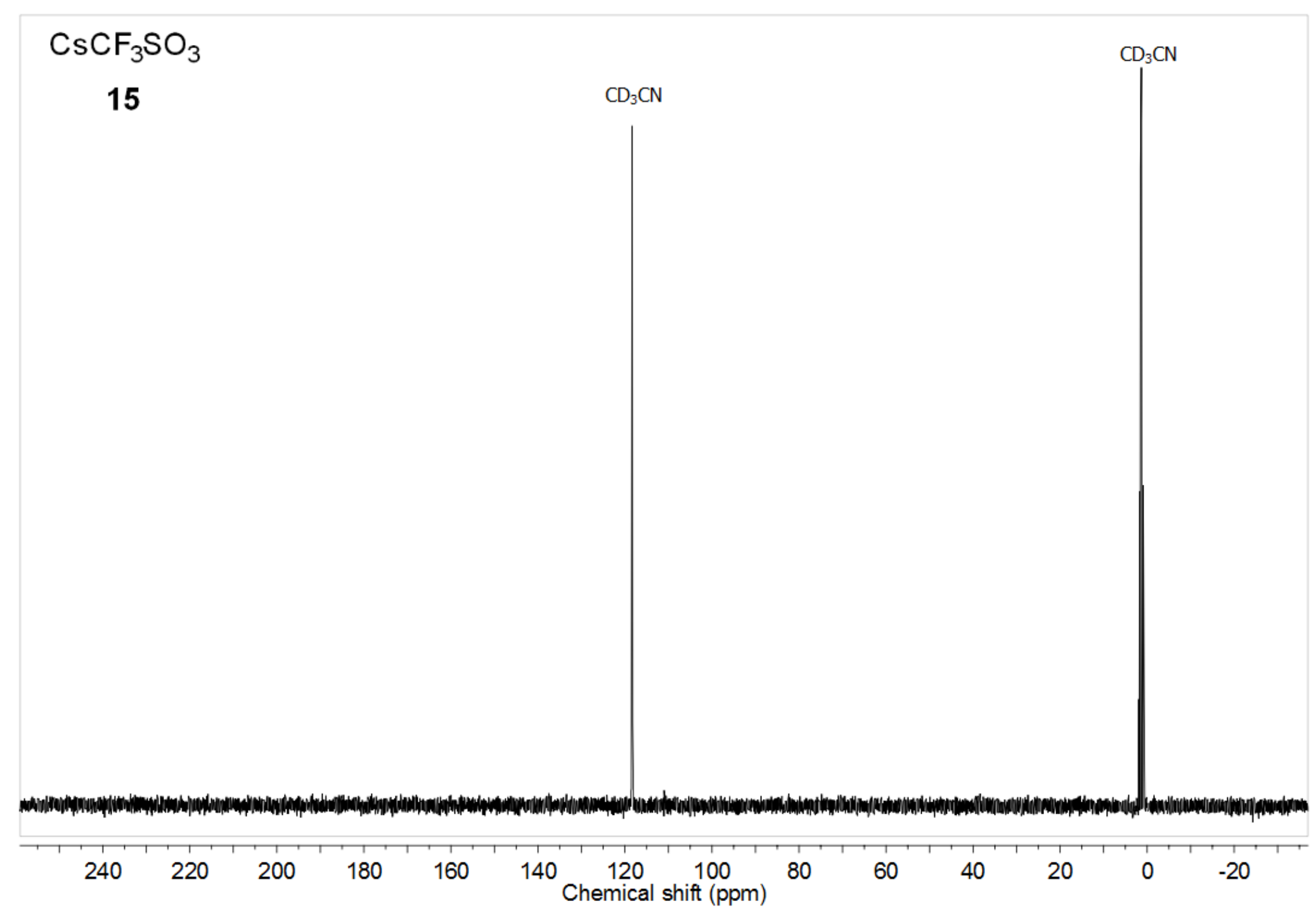

Figure S62. ${ }^{13} \mathrm{C}$ NMR (100 MHz, $\left.\mathrm{CD}_{3} \mathrm{CN}\right)$ spectrum of cesium triflate (15). 


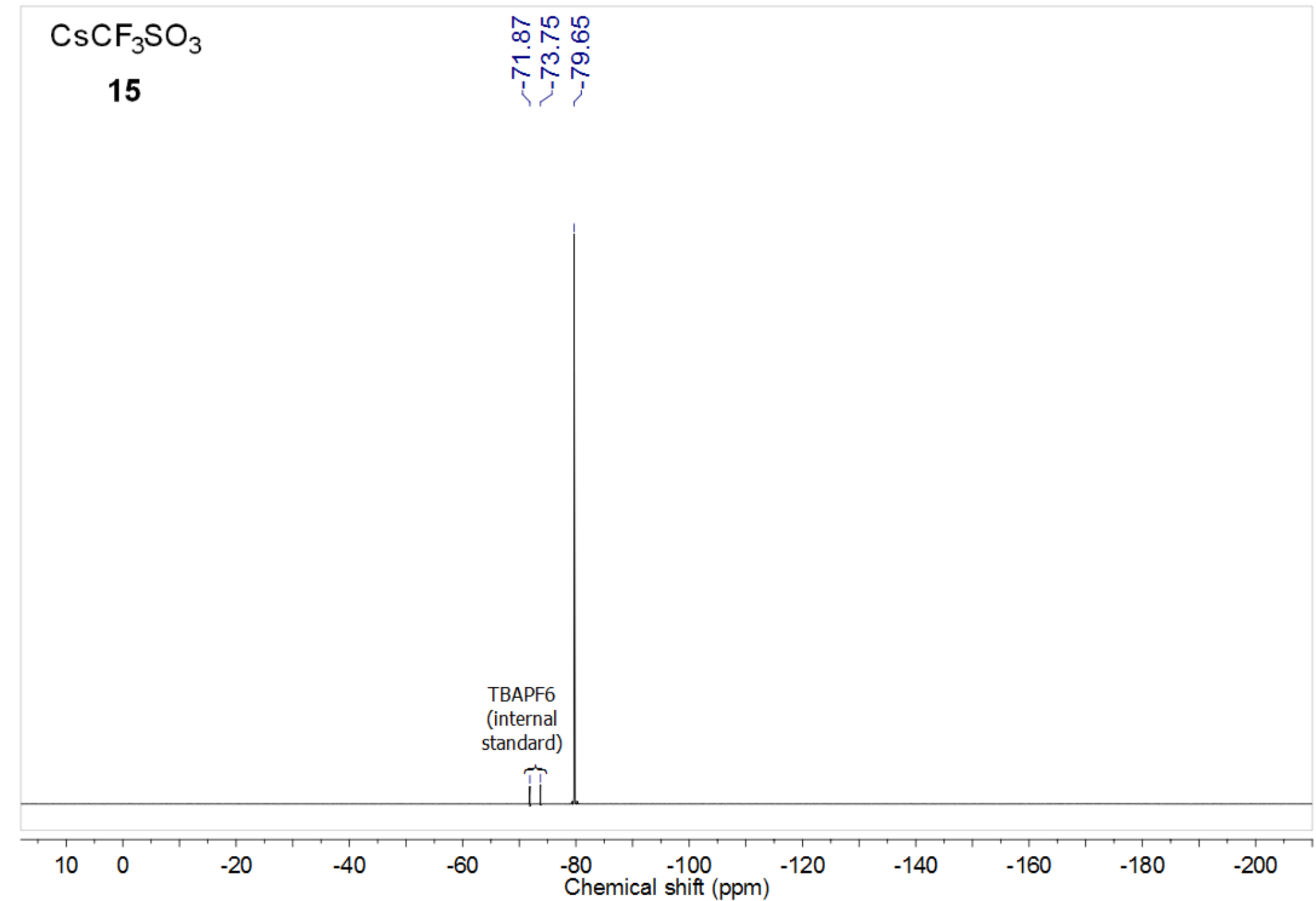

Figure S62. ${ }^{19} \mathrm{~F}$ NMR $\left(376 \mathrm{MHz}, \mathrm{CD}_{3} \mathrm{CN}\right)$ spectrum of cesium triflate (15). 


\section{Cartesian coordinates of calculated structures}

Table S3. Cartesian coordinates of the studied structures calculated at B3LYP-D3/6-31+G(d)/C-PCM:MeCN ( $\varepsilon=37.5)$ level of theory; the calculated total energies are given in atomic units (hartrees); 1 hartree $=2625.5 \mathrm{~kJ} \cdot \mathrm{mol}^{-1}$; calculated energy for single potassium cation is -599.800432 hartrees; interaction energy for the complex $\left(E_{\mathrm{int}}\right)$ is defined as $E_{\mathrm{int}}=E_{[\mathrm{K} c \mathbf{1}]_{+}}-\left(E_{\mathbf{1}}+E_{\mathrm{K}+}\right)$ and is given in $\mathrm{kJ} \cdot \mathrm{mol}^{-1}$.

\begin{tabular}{|c|c|c|c|}
\hline $\begin{array}{c}\text { trans }-\mathbf{1} \\
E=-4106.01615 \text { hartrees }\end{array}$ & $\begin{array}{c}\text { cis }-1 \\
E=-4106.00079 \text { hartrees } \\
\Delta \mathrm{E}_{\text {cis-trans }}=40.3 \mathrm{~kJ} \cdot \mathrm{mol}^{-1}\end{array}$ & $\begin{array}{c}{[\mathrm{K} \subset \text { trans }-\mathbf{1}]^{+}} \\
E=-4705.927903 \text { hartrees } \\
\Delta \mathrm{E}_{\mathrm{int}}=-292.3 \mathrm{~kJ} \cdot \mathrm{mol}^{-1}\end{array}$ & $\begin{array}{c}{[\mathrm{K} \subset \text { cis } \mathbf{- 1}]^{+}} \\
E=-4705.913807 \text { hartrees } \\
\Delta \mathrm{E}_{\mathrm{int}}=-295.6 \mathrm{~kJ} \cdot \mathrm{mol}^{-1}\end{array}$ \\
\hline C -3.145017 -1.128495 0.140630 & C -1.345020 0.510986 -1.234499 & C -0.367174 2.782328 0.667116 & C - $2.795330-0.432170-0.304498$ \\
\hline C -3.101515 $0.378056-0.205213$ & C $0.0971490 .059440-1.528345$ & C 1.0630192 .5037660 .163989 & C -2.396494 $1.056431-0.317196$ \\
\hline C - $1.6642440 .887377-0.440474$ & C $0.928195-0.192392-0.256908$ & C $1.3736081 .006650-0.011820$ & C - $0.8720231 .309895-0.329630$ \\
\hline C $-0.979916-0.046196-1.441082$ & C $0.114822-1.0430670 .724633$ & C $0.2261920 .326659-0.753159$ & C $-0.1509700 .339256-1.269552$ \\
\hline O -0.956610 - $1.369353-0.935407$ & O - $1.134430-0.4402681 .005622$ & O -0.994618 $0.531941-0.051833$ & O - $0.559911-1.006085-1.045405$ \\
\hline C - $2.245589-1.966190-0.783846$ & C - $1.993284-0.327122-0.128950$ & C -1.419190 $1.906875-0.017699$ & C - $1.954377-1.262329-1.271828$ \\
\hline C $1.219100-0.203258-2.520016$ & C $0.441071-1.9125023 .008358$ & C - $0.287891-1.972298-1.479590$ & C $2.191877-0.144555-1.858351$ \\
\hline C $2.5449690 .580471-2.386430$ & C $1.566645-1.6967644 .037268$ & C $0.606305-3.219375-1.568514$ & C $3.3599890 .866461-1.965154$ \\
\hline C $3.271641-0.128287-1.222308$ & C $1.231016-0.2857054 .537005$ & C $0.537143-3.744103-0.127456$ & C $4.3378790 .481044-0.846599$ \\
\hline C $2.495257-1.446574-1.033684$ & C -0.312113 -0.227088 4.439446 & C $-0.872848-3.3183480 .348524$ & C $3.819695-0.872874-0.316806$ \\
\hline O $1.582157-1.514635-2.149326$ & O -0.693031 -1.402327 3.678222 & O - $1.371964-2.412176-0.674391$ & O $2.756359-1.280835-1.215549$ \\
\hline C - $2.875543-2.313193-2.149902$ & C - $2.503624-1.689963-0.621595$ & C - $1.8859762 .395775-1.392396$ & C - $2.337204-1.109266-2.753648$ \\
\hline O - $1.913157-2.787859-3.084859$ & O $-2.919643-2.5540290 .437216$ & O -2.695252 $1.348014-1.920516$ & O - $1.409560-1.776809-3.598764$ \\
\hline C $0.652712-0.305803-3.940048$ & C $0.091081-3.3528902 .627701$ & C $-0.916714-1.470750-2.780319$ & C $1.691106-0.588145-3.237265$ \\
\hline C $1.724879-1.5263510 .280491$ & C -0.792237 1.0390113 .747545 & C - $0.869255-2.6256921 .699852$ & C $3.345644-0.7242231 .119615$ \\
\hline O $2.671357-1.6512271 .335625$ & O -2.207350 1.0212003 .630635 & O - $2.218240-2.3368432 .066132$ & O $2.942541-1.9851691 .648757$ \\
\hline C - $1.209303-3.950778-2.656247$ & C -3.835563 -1.980106 1.378240 & C -3.561586 $1.728600-2.986279$ & C - $1.503064-3.203356-3.611820$ \\
\hline C $-0.150753-4.280547-3.706472$ & C -4.820981 -3.038575 1.892177 & C $-3.9936450 .475775-3.720754$ & C $-0.135947-3.813235-3.837599$ \\
\hline O $0.786304-5.234068-3.204125$ & O $-6.137983-2.8982201 .351601$ & O -4.649263 -0.408255 -2.815620 & O $0.708187-3.584694-2.707963$ \\
\hline C $2.129770-1.3371692 .617778$ & C - 2.6781282 .0572332 .779650 & C - $2.350397-1.7871883 .381279$ & C $2.636393-1.9114073 .049708$ \\
\hline C $0.845426-2.1150512 .929942$ & C -4.160871 1.8022972 .513072 & C -2.218955 -0.274757 3.423406 & C $1.233073-1.3770613 .296033$ \\
\hline O $0.859247-2.4359274 .323478$ & O -4.744743 2.8464881 .736314 & O -3.351734 0.2943062 .759451 & O $0.267098-2.2944962 .782283$ \\
\hline C $1.821260-4.634648-2.430435$ & C -6.435978 -3.610096 0.160281 & C $-4.945910-1.669547-3.409372$ & C $1.874874-4.405974-2.695562$ \\
\hline
\end{tabular}




\begin{tabular}{|c|c|c|c|}
\hline C $2.748367-5.740498-1.950045$ & C -5.650725 -3.166699-1.070245 & C -5.794023 -2.480816-2.456802 & C $1.615141-5.753789-2.044336$ \\
\hline O $3.884453-5.155672-1.287107$ & O -5.646886 -1.729307-1.217449 & O -4.993852 -2.791112-1.292955 & O $1.335016-5.534203-0.637105$ \\
\hline C - $0.334263-3.0415574 .805756$ & C -4.410299 2.8217290 .348178 & C -3.588977 1.6545113 .119232 & C - $-0.257347-3.2287013 .724284$ \\
\hline O - $1.430979-3.9372762 .877278$ & O -4.750020 1.336321 -1.603674 & O -4.505277 2.227946 0.983822 & O - $1.080275-4.5538251 .825832$ \\
\hline C $3.976195-4.8590740 .036422$ & C -3.415637 $2.153884-4.887714$ & C -5.625460 -3.022206 -0.091382 & C - $4.456477-4.7029730 .462668$ \\
\hline C - $1.609706-4.8501521 .875051$ & C $-6.5653300 .036643-4.295399$ & C -5.555968 2.458210 0.131200 & C - $1.600567-7.4441760 .522205$ \\
\hline C $2.965884-4.9100541 .033419$ & C -3.886636 1.423980 -3.791809 & C -6.407840 -2.036689 0.550303 & C -3.059699-4.751433 0.557476 \\
\hline C $3.306763-4.5726932 .364513$ & C -4.468620 $2.098233-2.690070$ & C -6.841559-2.242012 1.864185 & C -2.440062 -4.633124 1.824168 \\
\hline C $4.583205-4.1753402 .711639$ & C - $4.6784613 .478849-2.783941$ & C -6.516295 -3.417991 2.540014 & C -3.240079-4.575852 2.968114 \\
\hline C $5.566658-4.0834171 .712287$ & C $-4.2638484 .182390-3.916825$ & C -5.736483 -4.389447 1.906611 & C -4.631627 -4.609377 2.856915 \\
\hline C $5.264974-4.4230480 .403096$ & C -3.616635 $3.529400-4.967855$ & C -5.289093 -4.187096 0.599771 & C -5.249091 -4.662031 1.606197 \\
\hline C -2.929357 -5.117661 1.496903 & C -7.951871 $0.105587-4.162809$ & C -5.665530 $3.708045-0.477753$ & C $-0.974400-8.4438061 .264900$ \\
\hline C -3.205072 -5.951869 0.415552 & C -8.576984 -0.450011 -3.042819 & C -6.659301 $3.931693-1.430939$ & C $0.418874-8.4654181 .383788$ \\
\hline C - $2.155140-6.532455-0.306946$ & C $-7.817955-1.084350-2.056148$ & C -7.551097 $2.908558-1.782957$ & C $1.194723-7.5044820 .729368$ \\
\hline C -0.839464 -6.258060 0.045788 & C $-6.433367-1.177295-2.195025$ & C -7.443451 $1.657854-1.185942$ & C $0.575370-6.520892-0.035059$ \\
\hline C -0.541876 -5.410316 1.129249 & C -5.799956 -0.605428 -3.313171 & C -6.445934 $1.421400-0.226583$ & C $-0.830205-6.463611-0.115625$ \\
\hline C - $0.747926-4.3208804 .088722$ & C -5.372203 $1.914069-0.441974$ & C -4.818662 2.145656 2.392547 & C - $0.349505-4.5944753 .065701$ \\
\hline N $1.655972-5.2340720 .640526$ & N -3.580610 $0.023140-3.796996$ & N -6.718805 -0.829500 -0.147411 & N - $2.377705-4.768348-0.698187$ \\
\hline N $0.770017-5.0881761 .531492$ & N -4.408879 -0.867842 -3.495848 & N -6.213497 0.1803690 .405585 & N - $1.373100-5.468804-0.974772$ \\
\hline O $0.3931680 .982252-4.468297$ & O $1.189054-3.9807071 .990285$ & O $0.071762-1.162822-3.744268$ & O $1.5740370 .562632-4.068047$ \\
\hline C - $1.3881502 .621028-4.210159$ & C $2.079787-4.120872-0.260441$ & C $1.4701600 .780730-4.150732$ & C -0.387279 $1.945397-4.506083$ \\
\hline C - $2.5541683 .230831-4.693058$ & C $2.230866-4.813177-1.470442$ & C $1.7039312 .036792-4.727050$ & C - $1.6239792 .170572-5.125233$ \\
\hline C -3.015367 4.424616 -4.137911 & C $3.216176-4.440468-2.385507$ & C $2.9664202 .625214-4.652657$ & C -2.358370 3.323684 -4.843909 \\
\hline C - $2.3031965 .033616-3.099375$ & C $4.071157-3.371335-2.096930$ & C $4.0110801 .963569-3.997383$ & C - $1.8651854 .264999-3.934422$ \\
\hline C - $1.1327524 .437389-2.625469$ & C $3.927326-2.680545-0.892801$ & C $3.7788820 .718059-3.412975$ & C - $0.6418034 .037499-3.302725$ \\
\hline C -0.676975 $3.232966-3.172150$ & C $2.937012-3.0526290 .022870$ & C $2.5131540 .125952-3.488306$ & C $0.0974932 .885879-3.590087$ \\
\hline C -0.948986 $1.301312-4.815646$ & C $0.977067-4.5326630 .696014$ & C $0.0933040 .155663-4.280285$ & C $0.4000090 .696266-4.863259$ \\
\hline O $2.3378611 .957496-2.157163$ & O $2.861238-1.7848943 .478989$ & O $1.907050-2.882565-1.988555$ & O $2.8926662 .192206-1.844151$ \\
\hline C $3.3980513 .996752-1.514476$ & C $5.142069-2.4375123 .598355$ & C $3.992911-3.376804-2.969979$ & C $3.4138114 .502722-1.779643$ \\
\hline C $2.8142785 .154222-2.042091$ & C $5.279645-3.3307382 .527625$ & C $4.240563-3.074125-4.313109$ & C $2.5983565 .372298-2.511269$ \\
\hline C $2.6745156 .298619-1.252073$ & C $6.457105-3.3694741 .781422$ & C $5.434718-2.455272-4.691580$ & C $2.1863296 .588348-1.959196$ \\
\hline С 3.1230376 .2936290 .072019 & C $7.517695-2.5169652 .106249$ & C $6.390271-2.127322-3.726431$ & C $2.5944976 .944231-0.671092$ \\
\hline
\end{tabular}




\begin{tabular}{|c|c|c|c|}
\hline C 3.6960025 .1364130 .608932 & C $7.392225-1.6279033 .176858$ & C $6.149653-2.425567-2.381449$ & C 3.4025016 .0750480 .068973 \\
\hline C $3.8249503 .992892-0.179880$ & C $6.207080-1.5879143 .917676$ & C $4.957192-3.047776-2.008299$ & C $3.8037314 .857824-0.481206$ \\
\hline C $3.5306372 .744075-2.339241$ & C $3.837455-2.3795194 .348554$ & C $2.677968-3.966113-2.532584$ & C $3.8258233 .168726-2.337849$ \\
\hline O $4.632416-0.332946-1.593893$ & O $1.773788-0.0696825 .829495$ & O $0.770227-5.142386-0.095750$ & O $5.6558660 .419758-1.378149$ \\
\hline C 5.8101640 .4837440 .392314 & C 2.9020912 .0185725 .180569 & C $2.675215-5.0992791 .455325$ & C 6.7869421 .8897670 .228227 \\
\hline C 5.1740800 .6637671 .626631 & C 2.5050713 .1686994 .490730 & C $2.875477-4.0564632 .368572$ & C 6.3747682 .1384291 .542426 \\
\hline C 5.4651181 .7768512 .421257 & C 3.3534503 .7630903 .549766 & C $4.149934-3.5179432 .568472$ & C 6.4422233 .4281242 .080084 \\
\hline C 6.3983962 .7205281 .986284 & C 4.6025313 .1998113 .281487 & C $5.241223-4.0253191 .859970$ & C 6.9262544 .4826951 .303952 \\
\hline C 7.0331282 .5529280 .750372 & C 5.0081902 .0500403 .969374 & C $5.053853-5.0768460 .955923$ & C $7.3365004 .244889-0.012774$ \\
\hline C $6.7375471 .442417-0.040545$ & C 4.1642791 .4694834 .914551 & C $3.778135-5.6036760 .752003$ & C $7.2646732 .957969-0.545360$ \\
\hline C $5.479060-0.701153-0.489226$ & C 1.9730811 .3186256 .153610 & C $1.288540-5.6297791 .160032$ & C $6.6875840 .505754-0.378369$ \\
\hline O - 0.9826200 .8936070 .807655 & O 1.2621871 .0741000 .290301 & O 1.5499960 .4173101 .270504 & O -0.361906 1.2065830 .995260 \\
\hline C -0.594339 3.301947 1.135712 & C 3.7341010 .9153700 .197273 & C 3.9748910 .0976151 .245782 & C - 0.1500343 .5950341 .453731 \\
\hline C - 1.8436003 .4800571 .738846 & C $3.7919961 .262807-1.156721$ & C 4.4533630 .9466722 .253253 & C - 1.1560133 .7788402 .413753 \\
\hline C -2.3671434.761509 1.915174 & C $4.9715971 .084891-1.881457$ & C 5.6964521 .5661662 .122838 & C - 1.8409094 .9902112 .496310 \\
\hline C -1.646848 5.8813701 .490073 & C $6.1105760 .566460-1.258026$ & C 6.4721851 .3487900 .977611 & C - 1.5300446 .0323501 .613852 \\
\hline C -0.397141 5.7088410 .887847 & C 6.0580330 .2139530 .093511 & C $6.0001820 .506958-0.032089$ & C -0.5359395.8533630.650181 \\
\hline C 0.1220574 .4248520 .708317 & C 4.8712180 .3767590 .812283 & C $4.757286-0.1159440 .105913$ & C 0.1516014 .6380980 .571522 \\
\hline C 0.0004961 .9193160 .973816 & C 2.4873061 .1577131 .020049 & C $2.614381-0.5457861 .364643$ & C 0.5522562 .2608971 .349207 \\
\hline O -3.888727 0.505307 -1.393297 & O -0.021066 -1.143852 -2.292579 & O $1.2120613 .181044-1.082995$ & O -2.993196 $1.636243-1.480010$ \\
\hline C -5.106432 $2.558903-0.777967$ & C $1.294466-0.357919-4.207765$ & C $2.9818284 .645043-0.241673$ & C -4.627948 $3.017840-0.278062$ \\
\hline C -6.209994 $1.916849-0.198862$ & С $0.1962330 .175608-4.897168$ & C 2.1899285 .7570320 .077612 & C -5.607760 $2.015884-0.259589$ \\
\hline C -7.017782 2.5868820.719080 & С $0.3821931 .165270-5.862395$ & C 2.5513056 .6040171 .125143 & C -6.641903 2.054008 0.676462 \\
\hline C -6.732578 3.9119621 .067808 & C $1.6700711 .630646-6.152827$ & C 3.7115936 .3484091 .865827 & C -6.715477 3.1030751 .599370 \\
\hline C -5.633361 4.556351 0.497429 & C $2.7678091 .104559-5.467684$ & C 4.5067805 .2447381 .550967 & C -5.7481964 4.110396 1.579419 \\
\hline C - $4.8208383 .878715-0.416545$ & C $2.5771600 .119675-4.494083$ & C 4.1393814 .3964220 .502512 & C - 4.7071674 .0624490 .648086 \\
\hline C -4.248994 $1.834073-1.791759$ & C $1.088992-1.423634-3.152155$ & C $2.5410633 .681821-1.319675$ & C -3.492316 2.963790 -1.279913 \\
\hline O -2.685364 -1.389830 1.462176 & O -1.414299 $1.869356-0.805639$ & O -0.471235 2.486303 2.056700 & O -2.593899 -0.991838 0.990917 \\
\hline C -3.723657 -0.011131 3.216174 & C $0.2120363 .438052-1.786083$ & C 0.2889962 .8433884 .279121 & C -3.150870 -0.769314 3.318742 \\
\hline C -2.675041 0.3950034 .055158 & C $0.7488863 .913453-0.582580$ & C 0.9959651 .6329214 .335771 & C - $1.998934-0.0364823 .636867$ \\
\hline C -2.719624 1.6309454 .700607 & C $2.0226594 .477825-0.550077$ & C 1.2555341 .0245705 .563679 & C - 1.5312910 .0060114 .950416 \\
\hline C -3.815184 2.480915 4.511745 & C $2.7763504 .579564-1.726013$ & C 0.8153511 .6212206 .751077 & C - $-2.205450-0.6864045 .962030$ \\
\hline
\end{tabular}




\begin{tabular}{|c|c|c|c|}
\hline C - 4.8578552 .0903403 .669405 & C $2.2493674 .106094-2.928654$ & C 0.1110662 .8260206 .699274 & C -3.352472 -1.4197915.650312 \\
\hline C - 4.8104250 .8491913 .029146 & C $0.9730193 .534636-2.954897$ & C - 0.1543733 .4320995 .466490 & C -3.820648 -1.460284 4.333464 \\
\hline C -3.656860 -1.350438 2.512862 & C -1.182413 2.852968 -1.822831 & C 0.0320803 .4903042 .940472 & C -3.675696 -0.773669 1.903073 \\
\hline H -4.187612 -1.460800 0.031591 & H - $1.9174750 .386089-2.161265$ & H - 0.5952723 .8412020 .479324 & H -3.851992 -0.504457 -0.592797 \\
\hline Н -3.548160 0.9460770 .615804 & Н $0.5943860 .836449-2.114084$ & Н 1.7672192 .8957050 .903443 & Н - 2.7883471 .5263350 .590548 \\
\hline H -1.696200 $1.897198-0.862992$ & H $1.828460-0.749070-0.532278$ & Н $2.2816860 .911071-0.616629$ & Н - $0.7153222 .321406-0.720299$ \\
\hline H - $2.045854-2.893569-0.243813$ & H -2.845178 0.2439030 .238425 & H -2.297568 1.8967330 .624518 & H - $2.088099-2.309172-0.988541$ \\
\hline Н $3.1265470 .413129-3.304075$ & H $1.433216-2.4187274 .853270$ & Н $0.136551-3.944720-2.247707$ & Н $3.8607540 .713052-2.929572$ \\
\hline H $3.2063540 .497801-0.324960$ & H 1.6726350 .4208063 .828802 & H $1.306345-3.2186370 .446094$ & H $4.2821151 .250702-0.066930$ \\
\hline H $3.163332-2.307313-1.119571$ & H -0.767417 -0.326156 5.430144 & H - $1.547209-4.1794670 .367960$ & H $4.589726-1.646865-0.379872$ \\
\hline H -3.664641 -3.062594 -1.978219 & H -3.333413 -1.500001 -1.309666 & H - $2.4724603 .313156-1.245105$ & H - $2.331978-0.064120-3.067448$ \\
\hline H -3.329011 -1.435771 -2.612454 & H -1.730099 -2.239373-1.158206 & H - $1.0603142 .623665-2.078285$ & Н $0.757645-1.144594-3.153283$ \\
\hline Н -0.240771 $-0.940441-3.928683$ & Н -0.804541 -3.341266 1.992763 & H - $1.552750-0.608627-2.557314$ & H $2.453019-1.263096-3.646218$ \\
\hline H $1.408117-0.806167-4.557308$ & H -0.161915 -3.888563 3.550407 & H - $1.559494-2.275519-3.156722$ & H $4.182390-0.3295401 .715158$ \\
\hline H $1.103398-0.6378100 .415520$ & H -0.466709 1.9147764 .333245 & H - $0.417610-3.2961092 .446325$ & H 2.5246870 .0020791 .155423 \\
\hline H $1.057616-2.3947640 .242078$ & H -0.333223 1.0962942 .754216 & Н -0.267933 -1.710713 1.641211 & H - $2.166143-3.516798-4.432501$ \\
\hline Н -0.707634 -3.774123 -1.699836 & H -3.259888 -1.546335 2.204679 & H -4.429233 $2.267936-2.583306$ & H - $-0.274784-4.889522-4.006619$ \\
\hline H - $1.901615-4.793605-2.519128$ & H -4.427617 -1.183906 0.915164 & H -3.038387 2.384119 -3.696957 & Н $0.332835-3.381215-4.734754$ \\
\hline H -0.606795 -4.723116 -4.597810 & H -4.417568 -4.044375 1.705662 & H -4.671259 $0.756666-4.541868$ & Н $2.714014-2.9339663 .432541$ \\
\hline Н $0.360977-3.354455-4.001447$ & H -4.946708 -2.916720 2.973184 & H -3.115982 -0.019055 -4.160539 & Н $3.381960-1.2881293 .564358$ \\
\hline Н $2.898565-1.6277793 .338935$ & H -2.550864 3.0458663 .249714 & H -3.349684-2.068862 3.728916 & H $1.072125-1.1954384 .365112$ \\
\hline H $1.963247-0.2516102 .697357$ & H -2.111768 2.053551 1.838170 & H -1.607005 -2.237184 4.054037 & H $1.070927-0.4307802 .771112$ \\
\hline H -0.055470 -1.540603 2.671430 & H -4.288358 0.8223262 .034761 & H -2.199120 0.0432124 .476596 & Н $2.254657-4.564425-3.714489$ \\
\hline Н $0.836968-3.0360392 .341524$ & H -4.707283 1.7835233 .461276 & H -1.293009 0.0680552 .945963 & Н $2.638218-3.854412-2.135677$ \\
\hline Н 2.390086 -3.915359 -3.036694 & H -6.265289-4.691852 0.292588 & Н -5.509738 -1.533929 -4.344937 & Н $2.496762-6.399825-2.135346$ \\
\hline H $1.419005-4.098185-1.565339$ & H -7.507476 -3.453602 -0.000660 & H -4.013666 -2.205088 -3.644322 & Н $0.757216-6.248043-2.509465$ \\
\hline Н $3.171411-6.272674-2.806667$ & H -6.071654 -3.642102 -1.963652 & Н -6.099345 -3.419831 -2.933428 & Н $0.399985-3.3281484 .598051$ \\
\hline Н $2.229034-6.445569-1.301932$ & H -4.602191 -3.455629 -0.975813 & H -6.679023 -1.910529 -2.168497 & H - $1.234208-2.8713344 .066569$ \\
\hline H -0.138762 -3.273850 5.857436 & H -4.474169 3.8597020 .013787 & H -3.770669 1.7318234 .202199 & Н -2.794261 -4.482208 3.949160 \\
\hline H - $1.176435-2.3335214 .759965$ & H -3.386927 2.4764830 .168873 & H -2.718470 2.2728162 .868303 & Н -5.231060 -4.563248 3.761293 \\
\hline H $2.521277-4.6166733 .110025$ & H -5.160915 4.015050 -1.976620 & H -7.436206 -1.467531 2.339436 & Н -6.331121 -4.660266 1.522173 \\
\hline H $4.815951-3.9198183 .740786$ & H -4.434818 5.254049 -3.961783 & H -6.865560 -3.569799 3.556867 & H - $1.575618-9.2046451 .753627$ \\
\hline
\end{tabular}




\begin{tabular}{|c|c|c|c|}
\hline H $6.571654-3.7534141 .960024$ & H -3.272240 4.082020 -5.836234 & Н -5.469309-5.303326 2.429020 & H $0.903852-9.2358421 .975924$ \\
\hline H $6.014876-4.365093-0.379534$ & H -8.541990 $0.591198-4.934526$ & H -4.652454-4.912084 0.101653 & Н $2.278214-7.5053030 .801386$ \\
\hline H -3.727478 -4.651623 2.066368 & H -9.655872 -0.386894 -2.932781 & H - $-4.9573284 .483408-0.203280$ & Н $0.647508-4.9383192 .777993$ \\
\hline H -4.236360 -6.154611 0.140614 & H -8.286832 -1.496385 -1.168351 & H -6.740596 4.907481 -1.900988 & H - $0.785833-5.3353903 .743723$ \\
\hline H -2.365287 -7.190799 -1.144821 & H -5.639418 1.0456840 .164283 & H -8.326498 $3.092392-2.520352$ & Н -2.011602 $1.440054-5.832839$ \\
\hline H -0.017443 -6.685532 -0.516893 & H -6.294225 $2.432258-0.729256$ & H -8.122026 $0.851738-1.444100$ & Н -3.317262 $3.485778-5.329476$ \\
\hline Н $0.123919-4.9378843 .859935$ & H $1.572888-5.650455-1.696352$ & H -5.653285 1.4548122 .544066 & H - $2.4396335 .159683-3.709594$ \\
\hline H - $1.445908-4.8906844 .716878$ & Н $3.318146-4.985465-3.320546$ & H -5.094754 3.1427412 .757778 & Н - $0.2562544 .753783-2.582217$ \\
\hline H -3.108364 $2.763508-5.504999$ & H $4.839852-3.077108-2.806951$ & Н $0.8951192 .550797-5.243165$ & H $1.0402102 .698760-3.087610$ \\
\hline Н -3.927726 $4.879201-4.515323$ & H $4.579723-1.844480-0.665516$ & Н $3.1364973 .599236-5.104248$ & Н $0.7130790 .755605-5.915852$ \\
\hline H -2.657339 5.965179-2.665660 & Н $2.825778-2.5185810 .959324$ & H $4.9950822 .421494-3.938553$ & H - $0.236709-0.189109-4.764916$ \\
\hline H -0.572432 $4.905349-1.823313$ & Н $0.938032-5.6296040 .768255$ & H $4.5846050 .197706-2.903983$ & Н $2.2800195 .092194-3.511998$ \\
\hline Н $0.2274372 .765151-2.800129$ & Н $0.002932-4.2112050 .298738$ & Н $2.333871-0.847122-3.045628$ & H $1.5500407 .255501-2.534484$ \\
\hline H -1.032334 $1.352807-5.911300$ & H $4.449625-3.9834762 .271966$ & Н - $0.1894290 .108301-5.341988$ & Н $2.2772557 .890736-0.241963$ \\
\hline H - $1.6318010 .503671-4.490814$ & Н $6.544853-4.0584830 .945750$ & H - $0.6587710 .786646-3.786989$ & Н 3.7161986 .3434291 .074368 \\
\hline Н $2.4674035 .156056-3.072923$ & Н $8.435937-2.5446751 .525682$ & Н $3.491804-3.315398-5.063939$ & H 4.4248934 .1769920 .093815 \\
\hline H $2.2184457 .192135-1.669747$ & H $8.212947-0.9633953 .433090$ & H $5.615499-2.222970-5.737738$ & Н $3.8063853 .163768-3.436914$ \\
\hline Н 3.0179007 .1845750 .684977 & Н $6.111179-0.8963834 .749894$ & H $7.317037-1.641668-4.020082$ & H $4.8394802 .912023-2.008264$ \\
\hline H 4.0387865 .1214581 .639991 & H $3.504862-3.3918244 .622175$ & Н $6.886052-2.171759-1.623771$ & Н 6.0024631 .3170442 .150494 \\
\hline H 4.2587613 .0885060 .235637 & Н $3.933539-1.7914645 .268990$ & H $4.766502-3.274520-0.963397$ & Н 6.1164633 .6050903 .101580 \\
\hline H $3.6485812 .974309-3.407768$ & Н 1.5203443 .5917994 .675636 & Н $2.142592-4.415809-3.381048$ & Н 6.9792895 .4860251 .717792 \\
\hline H $4.4048102 .170174-2.012278$ & H 3.0281064 .6501163 .012122 & Н $2.823286-4.736649-1.767497$ & H $7.7104185 .063249-0.622140$ \\
\hline H $4.446936-0.0723341 .953747$ & Н 5.2513213 .6407012 .529729 & Н $2.027679-3.6574922 .920262$ & H $7.5813362 .774485-1.569501$ \\
\hline H 4.9612051 .9062403 .375511 & Н 5.9720571 .5972963 .753975 & H $4.287133-2.6984903 .268697$ & H $7.6079120 .250299-0.911130$ \\
\hline H 6.6265493 .5863282 .602063 & H 4.4672480 .5691785 .440196 & Н $6.231980-3.6050002 .009597$ & Н $6.525420-0.2484570 .404032$ \\
\hline H 7.7555233 .2877850 .405044 & Н 2.4015921 .3013477 .160478 & Н $5.899726-5.4774460 .403994$ & H -1.401848 2.9635203 .089972 \\
\hline H $7.2281491 .311773-1.002679$ & H 1.0095131 .8441356 .205895 & Н $3.630529-6.4115160 .039145$ & H -2.620208 5.123099 3.241951 \\
\hline H $6.385311-1.100990-0.953784$ & Н $2.9111891 .671851-1.639984$ & H $1.305677-6.7164361 .041400$ & H -2.064968 6.976299 1.677620 \\
\hline H $5.009951-1.5012430 .095974$ & Н $5.0006881 .358070-2.933251$ & Н $0.596757-5.3855321 .976724$ & H - $-0.2872056 .655145-0.039055$ \\
\hline H -2.4094342.611601 2.057441 & H $7.0284400 .430307-1.824094$ & Н 3.8464171 .1204653 .139100 & Н $0.9256894 .502100-0.178133$ \\
\hline H - 3.3433684 .8783822 .376365 & H $6.927635-0.2110500 .585103$ & H 6.0600862 .2222052 .909266 & H 1.3710412 .3019360 .623582 \\
\hline H - 2.0585386 .8785701 .621727 & H 4.8220930 .0718761 .853761 & H 7.4390101 .8344120 .875257 & Н 0.9596961 .9548902 .317899 \\
\hline
\end{tabular}




\begin{tabular}{|c|c|c|c|}
\hline H 0.1724886 .5671280 .542365 & H 2.4775060 .4795621 .874854 & H $6.5941480 .332548-0.925503$ & H -5.544351 1.196822 -0.970438 \\
\hline H 1.0808604 .2930730 .217621 & Н 2.4950552 .1838421 .401244 & H $4.391096-0.775907-0.674301$ & H -7.389911 1.2653140 .687182 \\
\hline Н 0.7206371 .9071550 .149870 & H -0.804822 -0.175104-4.658349 & Н $2.490597-1.3223750 .604899$ & H -7.518960 3.1305972 .330703 \\
\hline H 0.5361151 .6321911 .886953 & H -0.477227 $1.576878-6.385718$ & Н $2.480011-1.0001552 .349897$ & H -5.791668 4.925063 2.297800 \\
\hline H -6.421936 $0.884065-0.463944$ & H $1.8137862 .402726-6.903988$ & H $1.2778255 .942053-0.484641$ & H -3.941069 4.8327910.651639 \\
\hline H -7.867478 2.076826 1.165603 & Н $3.7698441 .467790-5.680362$ & Н 1.9281847 .4606031 .368964 & H -3.824251 3.283985 -2.271466 \\
\hline H -7.361363 4.434083 1.784033 & Н $3.428708-0.275608-3.946670$ & H 3.9891777 .0055052 .685802 & H -2.681903 3.639779-0.974674 \\
\hline H -5.397183 5.5807350 .771771 & Н $0.841444-2.387362-3.609460$ & H 5.4036995 .0325052 .127180 & H - 1.4639770 .4759582 .844205 \\
\hline H -3.955093 4.374458 -0.846524 & H $2.007751-1.565197-2.571814$ & H 4.7439033 .5225760 .274458 & H - 0.6337120 .5733535 .183400 \\
\hline H -4.802930 $1.685157-2.724908$ & Н 0.1716103 .8115170 .331675 & Н $2.4782484 .165342-2.297836$ & H - $1.836446-0.6570786 .983976$ \\
\hline H -3.363514 2.428527 -2.038559 & Н 2.4332274 .8296210 .393378 & Н $3.2550342 .853272-1.404585$ & Н -3.879726 -1.967178 6.427337 \\
\hline H - $1.818708-0.2603974 .192763$ & Н $3.7719765 .014293-1.699309$ & H 1.3201591 .1722223 .408376 & H - $4.705486-2.0422424 .091328$ \\
\hline H -1.900395 1.9339245 .347165 & H $2.8312644 .163359-3.844852$ & H 1.8010540 .0845275 .594104 & H -4.436402 -1.555763 1.768176 \\
\hline H -3.848279 3.446203 5.009274 & Н $0.5730873 .146830-3.888910$ & H 1.0163621 .1470907 .708180 & H -4.159249 0.1904591 .687879 \\
\hline H -5.704367 2.7487573 .499638 & H -1.925567 $3.637975-1.639315$ & H -0.240810 3.2919947 .616046 & K $0.678385-2.9346360 .099529$ \\
\hline H -5.620181 0.5529782 .367686 & H -1.395865 2.433389 -2.812637 & H -0.712118 4.365277 5.429543 & H - $0.3716480 .619231-2.302231$ \\
\hline H -3.337111 -2.1295613.211510 & H -0.034895 -2.038504 0.289813 & H - 0.6942314 .3113303 .027262 & O $1.2132740 .429491-1.000036$ \\
\hline H -4.644990 -1.626021 2.119507 & O $0.846991-1.1092291 .910560$ & Н 0.9630263 .9193232 .541487 & H - $2.680822-7.4224570 .425848$ \\
\hline H - $1.528196-0.019327-2.389669$ & H -6.072620 $0.449495-5.169583$ & K -3.405732 -0.670450 0.028164 & H - $4.900480-4.736874-0.528025$ \\
\hline \multirow[t]{2}{*}{ O $0.3342190 .405688-1.593431$} & H -2.920418 $1.611114-5.688094$ & Н $0.1491160 .742720-1.761223$ & Н -3.357789 -1.495565 -2.890040 \\
\hline & & O $0.515693-1.032960-0.785292$ & H - $1.917305-3.583541-2.675422$ \\
\hline
\end{tabular}




\section{References}

1. Lewandowski, B.; Listkowski, A.; Petrova, K.; Jarosz, S., Functionalisation of terminal positions of sucrose - Part II: Preparation of 1,2,3,3',4,4'-hexa-Obenzylsucrose and 6,6'-Bis-O-(2-hydroxyethyl)-1,2,3,3',4,4'-hexa-O-benzylsucrose. 2011 (book chapter), in Carbohydrate Chemistry: Proven Synthetic Methods, vol.I, CRC Press, 413-430.

2. Yang, C.-T.; Fu, Y.; Huang, Y.-B.; Yi, J.; Guo, Q.-X.; Liu, L., Room-Temperature Copper-Catalyzed Carbon-Nitrogen Coupling of Aryl lodides and Bromides Promoted by Organic lonic Bases. Angew. Chem. Int. Ed. 2009, 48 (40), 7398-7401.

3. (a) Dąbrowa, K.; Niedbała, P.; Jurczak, J., Engineering Light-Mediated Bistable Azobenzene Switches Bearing Urea d-Aminoglucose Units for Chiral Discrimination of Carboxylates. J. Org. Chem. 2016, 81 (9), 3576-3584; (b) Dąbrowa, K.; Jurczak, J., Tetra-(meta-butylcarbamoyl)azobenzene: A Rationally Designed Photoswitch with Binding Affinity for Oxoanions in a Long-Lived Z-State. Org. Lett. 2017, 19 (6), 1378-1381.

4. (a) Frassineti, C.; Ghelli, S.; Gans, P.; Sabatini, A.; Moruzzi, M. S.; Vacca, A., Nuclear Magnetic Resonance as a Tool for Determining Protonation Constants of Natural Polyprotic Bases in Solution. Anal. Biochem. 1995, 231 (2), 374-382; (b) Frassineti, C.; Alderighi, L.; Gans, P.; Sabatini, A.; Vacca, A.; Ghelli, S., Determination of protonation constants of some fluorinated polyamines by means of $13 \mathrm{C}$ NMR data processed by the new computer program HypNMR2000. Protonation sequence in polyamines. Anal. Bioanal. Chem. 2003, 376 (7), 1041-1052; (c) Rodríguez-Barrientos, D.; Rojas-Hernández, A.; Gutiérrez, A.; Moya-Hernández, R.; Gómez-Balderas, R.; Ramírez-Silva, M. T., Determination of pKa values of tenoxicam from 1H NMR chemical shifts and of oxicams from electrophoretic mobilities (CZE) with the aid of programs SQUAD and HYPNMR. Talanta 2009, 80 (2), 754-762.

5. (a) Lowe, A. J.; Pfeffer, F. M.; Thordarson, P., Determining binding constants from $1 \mathrm{H}$ NMR titration data using global and local methods: a case study using [n] polynorbornane-based anion hosts. Supramol. Chem. 2012, 24 (8), 585-594; (b) Thordarson, P., Determining association constants from titration experiments in supramolecular chemistry. Chem. Soc. Rev. 2011, 40 (3), 1305-1323. 